\title{
Information Asymmetry around Operational Risk Announcements
}

\author{
Ahmed Barakat* Anna Chernobai ${ }^{\dagger}$ Mark Wahrenburg ${ }^{\ddagger}$
}

June 9,2014

\begin{abstract}
Operational risk incidences are likely to increase the degree of information asymmetry between firms and investors. We analyze operational risk disclosures by U.S. financial firms during 1995-2009 and their impact on different measures of information asymmetry in the firms' equity markets. Effective spreads and the price impact of trades are shown to increase around the first announcements of such events and to revert after the announcement of their settlement. This is especially pronounced for internal fraud and business practices related events. Market makers respond to higher information risk around the first press cutting date by increasing the quoted depth to accommodate an increase in trading volumes.

The degree of information asymmetry around operational risk events may be influenced by the bank's risk management function and the bank's governance structure. We indeed find that information asymmetry increases more strongly after events' first announcements when firms have weaker governance structures - lower board independence ratios, lower equity incentives of executive directors, and lower levels of institutional ownership. In contrast, the firms' risk management function has little to no impact on information asymmetry. We interpret this as evidence that the risk management function is primarily driven by regulatory compliance needs. The results of this study contribute to our understanding of information asymmetry around operational risk announcements. They help to shed light on the role that regulation and corporate governance can play in order to establish effective disclosure practices and to promote a liquid and transparent securities market.
\end{abstract}

Keywords: Operational risk, information asymmetry, market liquidity, bid-ask spread, corporate governance, enterprise risk management.

JEL Classification Numbers: D82, G14, G30.

\footnotetext{
${ }^{*}$ Economics and Finance Division, Nottingham University Business School, UK, e-mail: Ahmed.Barakat@nottingham.ac.uk.

${ }^{\dagger}$ Corresponding author. Department of Finance, M.J. Whitman School of Management, Syracuse University, 721 University Avenue, Syracuse, NY 13244, USA, phone: +1-315-443-3357, fax: (315) 442-1461, e-mail: annac@syr.edu.

${ }^{\ddagger}$ Department of Finance, Faculty of Economics and Business Administration, Goethe University, Frankfurt am Main, Germany, e-mail: wahrenburg@finance.uni-frankfurt.de. We thank the participants of 2013 Financial Globalization and Sustainable Finance: Implications for Policy and Practice conference and Center for Financial Studies of University of Frankfurt's 2013 conference Operational Risk-Management and Measurement for extensive comments that helped significantly improve the paper. We are grateful to IBM for providing operational loss data. Chernobai acknowledges financial support from the M.J. Whitman School of Management at Syracuse University.
} 


\title{
Information Asymmetry around Operational Risk Announcements
}

This version: June 9, 2014

\begin{abstract}
Operational risk incidences are likely to increase the degree of information asymmetry between firms and investors. We analyze operational risk disclosures by U.S. financial firms during 1995-2009 and their impact on different measures of information asymmetry in the firms' equity markets. Effective spreads and the price impact of trades are shown to increase around the first announcements of such events and to revert after the announcement of their settlement. This is especially pronounced for internal fraud and business practices related events. Market makers respond to higher information risk around the first press cutting date by increasing the quoted depth to accommodate an increase in trading volumes.

The degree of information asymmetry around operational risk events may be influenced by the bank's risk management function and the bank's governance structure. We indeed find that information asymmetry increases more strongly after events' first announcements when firms have weaker governance structures - lower board independence ratios, lower equity incentives of executive directors, and lower levels of institutional ownership. In contrast, the firms' risk management function has little to no impact on information asymmetry. We interpret this as evidence that the risk management function is primarily driven by regulatory compliance needs. The results of this study contribute to our understanding of information asymmetry around operational risk announcements. They help to shed light on the role that regulation and corporate governance can play in order to establish effective disclosure practices and to promote a liquid and transparent securities market.
\end{abstract}

Keywords: Operational risk, information asymmetry, market liquidity, bid-ask spread, corporate governance, enterprise risk management.

JEL Classification Numbers: D82, G14, G30. 


\section{Introduction}

We study information asymmetry in the equity market around operational risk announcements in U.S. public financial firms. Better disclosure practices of financial information improve liquidity, provide a monitoring role over the behavior of senior management, and help maintain the trust of stakeholdersshareholders, supervisors, governments, and depositors. Diamond (1985) argued that releasing information makes shareholders better-off by maximizing their welfare. Recent U.S. regulatory initiatives that address disclosure include the Gramm-Leach-Bliley Act (GLBA) of 1999 that broadens the range of permissible banking activities and adds provisions regarding information-sharing, the Health Insurance Portability and Accountability Act (HIPAA) of 1996 that deals with security and privacy of data in the healthcare industry, the Basel II Capital Accord of 2001 that mandates regulatory capital for risks and their market disclosure, the Sarbanes-Oxley Act (SOX) of 2002 that mandates disclosures of internal control weaknesses in compliance with the SEC's disclosure laws, ${ }^{1}$ and the Dodd-Frank Act of 2010 that calls for stricter reporting and disclosure requirements in the financial industry, along with a mortgage reform and consumer protection rules.

The Basel Committee on Banking Supervision (BCBS) mandates the measurement and management of operational risk, defined as the risk of loss resulting from inadequate or failed internal processes, people, systems, or from external events. Operational risk may arise from diverse causes, such as unauthorized transactions, business disruptions due to technology and software failures, flawed financial models and products, poor business practices, natural disasters, employment issues and discrimination, and execution and delivery failures. Along with credit, market, and liquidity risks, operational risk has been acknowledged as a major source of material failures in financial firms. Trading errors and excessive risk-taking that led to a $\$ 6.2$ billion trading fiasco for JPMorgan Chase in 2012 ("London Whale"), Bernard Madoff's $\$ 50$ billion Ponzi scheme in 2008 , a $\$ 7.2$ billion trading loss at Société Générale in 2008, and the colossal losses from the September 11, 2001 terrorist attacks, are some recent examples. Chernobai, Jorion, and $\mathrm{Yu}$ (2011) showed that operational risk events are manifestations of internal control weaknesses and can be traced to improper business practices, weak economy, poor governance, and excessive risk-taking of executives. Wang and Hsu (2013) also found that stronger governance helps reduce occurrence of operational risk in financial firms. Basel II Capital Accord's Pillar III calls for more stringent market discipline and transparency via public disclosures of operational risk:

"The Committee aims to encourage market discipline by developing a set of disclosure requirements which will allow market participants to assess key pieces of information on the scope of application, capital, risk exposures, risk assessment processes, and hence the capital adequacy of the institution. In principle, banks' disclosures should be consistent with how senior management and the board of directors assess and manage the risks of the bank." (BCBS, 2006b, p. 226)

\footnotetext{
${ }^{1}$ SOX's relevant sections are Section 302 (Corporate Responsibility for Financial Reports) and Section 404 (Management Assessment of Internal Controls).
} 
To date, much of academic work on operational risk has been focused in the area of Pillar I of the Capital Accord that deals with the quantification of the regulatory risk capital. Recent studies of the equity market reaction to operational risk public announcements (Perry and de Fontnouvelle, 2005; Cummins, Lewis, and Wei, 2006; Gillet, Hübner, and Plunus, 2010) found that such news spur large drops in market prices, in particular for internal fraud events. Cummins, Lewis, and Wei (2006) showed that the cumulative abnormal returns are over $1 \%$ for banks and over $3 \%$ for insurers, and Gillet, Hübner, and Plunus (2010) found the cumulative abnormal returns to exceed 4\%. Motivated by recent regulatory advancements and prior research on operational risk, our question is: if operational risk announcements are informative releases, then do such releases affect information asymmetry between informed and uninformed traders in the equity market, and how?

Information asymmetry arises from differential information between informed and non-informed traders. In classical information asymmetry models (e.g., Copeland and Galai, 1983; Glosten and Milgrom, 1985), informed traders (e.g., large shareholders, financial analysts, creditors, and managers at competing firms) possess superior price-relevant firm-specific information not available to non-informed traders, or can extract private information from public releases. They profit from trading on private information (not yet) available to uninformed traders (e.g., market makers and discretionary liquidity traders). Market makers bear losses incurred due to the informational disadvantage when they make public the prices at which they commit to sell or buy; however, they offset them by imposing a bid-ask spread — wide enough to recoup the losses but tight enough to maintain fair liquidity demand. Hence, bid-ask spreads widen when market makers perceive higher levels of information asymmetry. Market makers may also reduce the quoted depth, thus adversely affecting liquidity.

Information asymmetry has been studied predominantly in the context of corporate earnings announcements. Bessembinder and Kaufman (1997), Stoll (2000), Venkataraman (2001), Chung, Elder, and Kim (2010), Bhattacharya, Desai, and Venkataraman (2012), and Bhattacharya, Ecker, Olsson, and Schipper (2012) found increased levels of information asymmetry around such announcements. ${ }^{2}$ Kim and Verrecchia (1994), Lee, Mucklow, and Ready (1993), Krinsky and Lee (1996), and Affleck-Graves, Callahan, and Chipalkatti (2002) showed that market makers act to increased information asymmetry around earnings releases by temporarily widening the bid-ask spread. By doing so, they attempt to protect themselves against informed investors who may be responsible for the high volumes and volatility in trading (Lee, Mucklow, and Ready, 1993; Easley and O’Hara, 1992; Harris and Raviv, 1993).

Earnings announcements are scheduled releases. For scheduled announcements, elevated trading prior to the release is primarily due to informed traders who trade to profit from information leakage, but may also be enhanced by uninformed traders who try to gamble on the upcoming news. In contrast, operational risk announcements are unscheduled and almost always constitute bad surprises to investors. When an event is unscheduled, any excess trading prior to the announcement is accounted for by informed

\footnotetext{
${ }^{2}$ Recent studies of corporate earnings restatement announcements (Palmrose, Richardson, and Scholz, 2004; Anderson and Yohn, 2002) also found that information asymmetry is increased around such news releases.
} 
traders. Literature on unscheduled announcements is sparse. Chae (2005) studied information asymmetry around the announcements of acquisition, target, and Moody's bond ratings changes, and Brooks, Patel, and Su (2003) investigated CEO deaths, plane crashes, and plant explosions. These studies found that information asymmetry increases in general, but their data consisted of announcements of many diverse causes without focusing on a single one. Our study differs from these by focusing on a single well-defined class of unscheduled announcements - operational risk events. In addition to studying information asymmetry around the first press cutting of such events, we also study it around the settlement announcements (that are more anticipated).

"Banks' disclosures should be consistent with how senior management and the board of directors assess and manage the risks of the bank." (BCBS, 2006b, p. 226) The quality of information disclosed by the management is positively associated with the strength of corporate governance (Klein, 2002; Ajinkya, Bhojraj, and Sengupta, 2005; Karamanou and Vafeas, 2005). Kanagaretnam, Lobo, and Whalen (2007) found that firms with more active and independent boards and with higher insider holdings incur less information asymmetry around quarterly earnings releases. Prior research showed operational risk to be inversely related to the strength of corporate governance (Chernobai, Jorion, and Yu, 2011; Wang and Hsu, 2013). Establishments of operational risk committees and Chief Operational Risk Officer positions should reduce lower-tail risk and also promote better communication of risk to the senior management and key stakeholders. This study examines whether better governance and risk management initiatives improve disclosure quality and reduce information asymmetry around operational risk announcements.

Using a rich sample of 331 operational risk announcements from U.S. financial firms during 19952009 and examine their trades and quotes on NYSE, AMEX, and NASDAQ exchanges. We study separately the first press cutting and settlement announcements. We find that information asymmetrymeasured by effective spread and price impact of trade (and their changes from the non-event period) significantly increases around operational risk first announcements but decreases around the settlement announcements, particularly for internal fraud events and events related to flawed business practices. Furthermore, firms with stronger governance (higher board independence ratio, higher equity incentives of insiders, and higher institutional ownership) experience lower levels of information asymmetry around the first announcements, and around settlements better governed firms see a smaller reduction in information asymmetry, but that the effect of risk management initiatives is limited. We interpret this as evidence of the risk management function being primarily driven by the need for regulatory compliance.

To the best of our knowledge, this is the first study that investigates market microstructure around operational risk announcements in financial firms. Identifying the factors affecting information asymmetry around such events may help regulators develop policies that would ensure a transparent and liquid securities market, which would provide investors with greater confidence in their investments. This paper proceeds as follows. Sections 2 and 3 describe our operational risk data and our measures of information asymmetry. Section 4 develops testable research hypotheses. Section 5 describes our research design and variables. Section 6 presents our empirical findings. Section 7 discusses liquidity. Section 8 concludes. 


\section{Description of Operational Risk Announcements Data}

Following Basel II, we categorize operational risk into seven main event types:

1. Internal Fraud: events intended to defraud, misappropriate property, or circumvent regulations or company policy that involve at least one internal party. Examples: unauthorized trading and theft.

2. External Fraud: events intended to defraud, misappropriate property, or circumvent the law performed by an external party. Examples: check kiting and breach of system security.

3. Employment Practices and Workplace Safety: events inconsistent with employment, health, or safety agreements. Examples: losses arising from employee relations, safety of the environment, and diversity and discrimination.

4. Clients, Products, and Business Practices: events due to failures to comply with a professional obligation to clients and improper design of a product. Examples: improper business and market practices, product flaws, and faulty advisory activities.

5. Damage to Physical Assets: events leading to a damage or loss of physical assets either from natural disasters or man-made disasters. Examples: fires, floods, hurricanes, vandalism, and terrorism.

6. Business Disruption and System Failures: events causing disruption of business or system failures. Examples: hardware failures, software bugs, and computer viruses.

7. Execution, Delivery, and Process Management: events due to failed transaction processing or process management occurring from relations with trade counterparties and vendors. Examples: losses from faulty transaction execution and maintenance, customer intake and documentation.

The source of our operational risk announcements data is the Algo Financial Institutions Risk Scenario Trends (Algo FIRST) database, marketed by IBM. ${ }^{3}$ FIRST's primary purpose is to assist financial institutions to understand, identify, and manage their operational risk through a comprehensive collection (over 13,000 entries) of operational risk case studies. Nearly three quarters of the recorded events are from financial institutions and more than half are from the U.S. The information is collected from public sources, such as the media, the Securities and Exchange Commission's (SEC) press releases, and court orders. As such, all information is readily available to investors and provides an ideal basis for our research. Details on each announcement include firm name, dates, event type, loss amount, claimant name, geographical location, and a detailed narrative. ${ }^{4}$

For most operational risk events, announcements are made over a period of time, each announcement marking a distinct development of the event. Gillet, Hübner, and Plunus (2010) studied the market reaction around the three timings: (1) the first press cutting date marking the first mentioning of the event, (2) the recognition date when the company announces the event, and (3) the settlement date, on which the settlement occurs. But the first two timings often coincide. Hence, we use two timings

\footnotetext{
${ }^{3}$ IBM acquired the FIRST database after its acquisition of Algorithmics, Inc. in October 2011.

${ }^{4}$ The database was previously used in Wang and Hsu (2013), Chernobai, Jorion, and Yu (2011), Gillet, Hübner, and Plunus (2010), Cummins, Lewis, and Wei (2006), Rosenberg and Schuermann (2006), and Perry and de Fontnouvelle (2005).
} 
instead: the first is the first press cutting date and the second is the announcement of settlement. In the cases when the announcement of an upcoming settlement is made prior to the actual settlement date, we use the former date for the settlement date. Whenever the settlement announcement is the first announcement available on a particular event, we retain no date for the first announcement. As such, while for the majority of events in our sample we have both the first announcement and settlement dates, for some of the more recent ones only the first announcement information is available, and for another few we have only the settlements.

We focus on operational risk announcements in publicly traded U.S. financial firms. We further restrict our data to events with losses that are material in nature, in excess of $\$ 10$ million. ${ }^{5}$ Constrained by availability of the governance data, we narrow our sample period to 1995-2009. We then exclude events with unclear first press cutting date and settlement date, with unclear firm name, that are random in nature (those due to terrorism or natural disasters in the category Damage to Physical Assets), with unavailable TAQ data, or with missing market or governance data. We then check the dates for consistency with the LexisNexis and Factiva business news databases. We also excluded one event in firm with stock price under $\$ 1$ and another event that had less than 5 trades per day. Our final sample contains 331 events. The sample selection procedure is summarized in Table 1.

Figure 1 illustrates the time series of operational risk events' announcements. The frequency increased over the sample period. A pronounced jump is evident around 2002, which coincides with the passage of the Sarbanes-Oxley Act. Another jump occurs around 2008 and is likely a consequence of the financial crisis. Figure 2 illustrates average cumulative abnormal equity returns (CARs) for the event window [$20,+10]$. CARs are negative around first announcements and positive around settlement announcements, consistent with earlier empirical findings (Gillet, Hübner, and Plunus, 2010; Cummins, Lewis, and Wei, 2006; Perry and de Fontnouvelle, 2005). CARs are $-1.64 \%$ over the event window $[-3,+3]$ and $-7.83 \%$ over the event window $[-20,+10]$ around first announcements. For settlement announcements, these are $1.57 \%$ and $5.73 \%$, respectively. These results are statistically significant at $1 \%$ level.

Table 2 provides additional description of our data. From Panel A, the majority of the announcements are of Clients, Products, and Business Practices (CPBP) type $(57.7 \%$ of the first and $68.8 \%$ of the settlement announcements), followed by internal fraud (15.8\% and $12.8 \%$, respectively) and external fraud ( $13.3 \%$ and $7 \%$, respectively). Only about $30 \%$ of the first and $53 \%$ of the settlement announcements are self-disclosed; the majority are disclosed by a third party, such as a regulatory authority (e.g., the SEC and the National Association of Securities Dealers (NASD)), shareholder, client, or court, and are not accompanied by a statement by the firms. This is particularly evident for the first announcements in the CPBP category, in which events are typically linked to failed business strategies that firms are reluctant

\footnotetext{
${ }^{5}$ For many announcements, the information on the loss amount is absent from the initial announcement but is either estimated later or accumulates over time as a result of fines and payments to third parties. Also, sometimes the initial announcement contains an estimate of loss rather than the exact amount. In such cases, we treat the estimate as an actual loss amount. Our sample contains the events with loss amount known to be in excess of $\$ 10$ million at the present time (as of 2014), regardless of the actual timing at which the loss amount became known.
} 
to reveal to the public voluntarily; notably, for these events the pattern reverses around settlements. For internal fraud the distribution is fairly uniform, perhaps because firms believe that their disclosure is less detrimental to the firm's public status. The fact that the majority of the first announcements are involuntary in nature alleviates concerns over self-selection bias. Panel A also informs about events that disclose the loss amount. For over half of our events, the loss information is contained in the initial announcement, and for others it is missing (it is often released with a delay by weeks, months, or even years). In contrast, almost all (98\%) press releases of settlements include the loss amount. Panel B of Table 2 reports the distribution of events by the two-digit Standard Industry Classification (SIC) code. Roughly one third of events $(32.9 \%)$ occurred in banks, another third in securities and commodity brokers $(33.2 \%), 23 \%$ in insurance, and less than $12 \%$ are in non-depository institutions and real estate firms.

\section{Measures of Information Asymmetry}

Bid-ask spread is commonly decomposed into three components, each reflecting particular costs to the market maker (Copeland and Galai, 1983; Ho and Stoll, 1981, 1983; Glosten and Milgrom, 1985; Glosten, 1987; Glosten and Harris, 1988; Grossman and Miller, 1988; Hasbrouck, 1988; Stoll, 1978, 1989). Order processing costs compensate market makers for the time they take to stay able to match buy and sell orders and perform the paperwork involved in the transaction. Inventory holding costs compensate market makers for holding less than fully diversified portfolios. Adverse selection costs compensate market makers for undertaking the risk of dealing with more informed traders who may possess superior information or who may be able to process information in a faster and cost-efficient manner; this risk is known as information risk. The adverse selection component is the one linked to information asymmetry and reflects how market makers act as uninformed traders and estimate their information risk associated with trading alongside informed traders. ${ }^{6}$

Our first measure of information asymmetry is percentage effective spread (Lee, 1993; Huang and Stoll, 1996). Quoted bid-ask spread does not necessarily capture trading costs for transactions occurring outside the posted quotes, because an order whose size exceeds the quoted quantity at the best prices may be completed at a price outside the bid-ask spread (Lee, 1993; Huang and Stoll, 1996; and Bhattacharya, Desai, and Venkataraman, 2012). Therefore, effective spread is a better measure of trading costs as it accounts for trades both inside and outside the quotes. Unlike quoted spread, effective spread is estimated using ex post trading costs of executed trades. In essence, effective spread calculates the deviation of the execution price from the true underlying value of the security and is computed as:

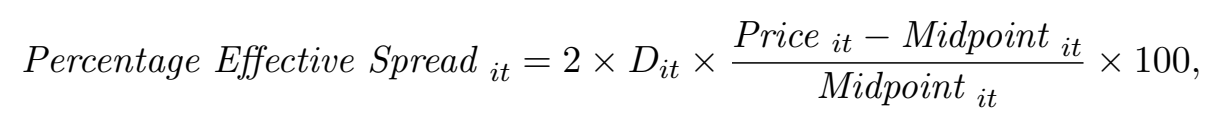

where Price $_{i t}$ is the transaction price at time $t$ for security $i$ and Midpoint $t_{i t}$ is the midpoint of the quoted

\footnotetext{
${ }^{6}$ Studies using quoted spreads as a measure of information asymmetry include Copeland and Galai (1983), Glosten and Milgrom (1985), Kim and Verrecchia (1994), Krinsky and Lee (1996), and Affleck-Graves, Callahan, and Chipalkatti (2002).
} 
ask and bid prices immediately prior to the transaction. The variable $D_{i t}$ is 1 for market buy orders and -1 for sell orders. The multiplication by 2 accounts for the round trip cost of transactions. Following Bhattacharya, Ecker, Olsson, and Schipper (2012), Bhattacharya, Desai, and Venkataraman (2012), Chung, Elder, and Kim (2010), and Bessembinder and Kaufman (1997), for the midpoint we use the midpoint of the last quote immediately prior to the trade. Effective spread can be viewed as an estimate of the execution cost paid by traders and the gross revenue earned by liquidity providers, and captures both the non-informational costs (inventory costs, order processing costs, and possibly market maker rents) and informational (adverse selection) costs of liquidity provision. We use two versions of effective spread. The first one is in the level form as defined in Equation (1), and the second one is the change in percentage effective spread as in Bhattacharya, Desai, and Venkataraman (2012) and Affleck-Graves, Callahan, and Chipalkatti (2002), which is the difference between daily average percentage effective spread for each of the days in the event window and the average percentage effective spread during the non-event period. This difference should be positive during periods of heightened information asymmetry.

Our second measure of information asymmetry is percentage price impact of trade proposed by Huang and Stoll (1996). It estimates the adverse selection risk perceived by liquidity providers based on the price adjustments observed subsequent to a transaction. For anticipated good (bad) news, the market maker expects the informed traders to submit buy (sell) orders. However, non-informed traders are equally likely to submit buy and sell orders, creating order flow imbalance. For an undervalued security this imbalance will tend to be positive and for an overvalued security negative. Market makers react to such order flow imbalances by widening spreads and adjusting quotes upward following buy orders and downward following sell orders. Hence, these price adjustments capture market makers' assessment of the proportion and the extent of information asymmetry between informed and liquidity traders (Bhattacharya, Desai, and Venkataraman, 2012; Glosten and Milgrom, 1985). The percentage price impact is computed as:

$$
\text { Percentage Price Impact of Trade }{ }_{i t}=2 \times D_{i t} \times \frac{\text { Price }_{i, t+\tau}-\text { Midpoint }_{i t}}{\text { Midpoint }_{i t}} \times 100 \text {, }
$$

where Price $_{i, t+\tau}$ is the first transaction price $\tau$ minutes after time $t$ and Midpoint ${ }_{i t}$ is the midpoint of the quoted ask and bid prices immediately prior to time $t$. Literature considers various time horizons to estimate an asset's post-trade economic value - from $\tau=5$ minutes to $\tau=30$ minutes. However, Werner (2004) reports that spread measures obtained in large samples are relatively insensitive to the choice of the post-trade benchmark. In our study, we use $\tau=30$ minutes, which has been the choice in Bhattacharya, Desai, and Venkataraman (2012), Bhattacharya, Ecker, Olsson, and Schipper (2012), Venkataraman (2001), and Bessembinder and Kaufman (1997). In addition to the level form of this variable, as in Bhattacharya, Desai, and Venkataraman (2012), we also use the change in percentage price impact of trade which is the difference between percentage price impact of trade for each of the days in the event window and the average percentage price impact of trade during the non-event period.

The effective spread and price impact of trade have been used extensively in recent literature to 
quantify information asymmetry: Bessembinder and Kaufman (1997), Stoll (2000), Venkataraman (2001), Chung, Elder, and Kim (2010), Bhattacharya, Desai, and Venkataraman (2012), and Bhattacharya, Ecker, Olsson, and Schipper (2012). Computations of Equations (1) and (2) require categorizing trades as seller- or buyer-initiated. Two algorithms have been proposed. In the first algorithm proposed by Lee and Ready (1991), trades completed at prices above (below) the midpoint price are classified as buy (sell); trades executed at the midpoint are assigned according to the "tick test" where trades at a higher (lower) price relative to the most recent trade are classified as buys (sells). In another algorithm proposed by Ellis, Michaely, and O'Hara (2000), trades executed at the ask (bid) quote are classified as customer buys (sells), and the tick test is used for all other trades. Finucane (2000) showed that although the two algorithms produce very similar results, Lee and Ready's (1991) algorithm slightly outperforms the second algorithm. In this paper, we estimated our models using both algorithms and the results were practically identical. In what follows, all results use Lee and Ready's (1991) algorithm.

\section{Hypotheses Development}

Higher quality disclosures reduce information asymmetry between market participants-informed and non-informed (liquidity) traders. Kim and Verrecchia (1994) argued that disclosures about firm's fundamentals, such as earnings announcements, stimulate informed judgments among traders. Informed traders are better able to perform a superior assessment of the information and to process public disclosures into private information, than market makers. In anticipation of such announcements, information asymmetry in the market rises as investors increase their search for private information that would allow them to profit once earnings are made public (Bhattacharya, Desai, and Venkataraman, 2012; Bhattacharya, Ecker, Olsson, and Schipper, 2012; Chung, Elder, and Kim, 2010; Stoll, 2000; Fu, Kraft, and Zhang, 2012; Brown, Hillegeist, and Lo, 2009).

Earnings announcements are scheduled. For unscheduled announcements, information asymmetry has been documented to increase as well. Chae (2005) studied abnormal trading volume around unscheduled announcements of acquisition, target, and Moody's bond ratings changes. Brooks, Patel, and Su (2003) studied adverse events such as a CEO death, plane crashes, and plant explosions. Both studies documented an increase in information asymmetry. Operational risk events are similar to these types of events. On the basis of previous empirical research, we hypothesize that operational risk first announcements increase information asymmetry in the equity markets. Furthermore, because such announcements are unanticipated by investors, we expect this increase in information asymmetry to be more pronounced immediately following the announcement.

In turn, operational risk settlement announcements are perceived by investors as positive news (Figure 2B; Gillet, Hübner, and Plunus, 2010) that have been long anticipated. Because news of an achieved resolution agreement brings the event to a closure, we anticipate information asymmetry to decrease around the press release. Furthermore, this decline should be more pronounced immediately following 
the announcement. We formulate our first set of hypotheses as follows.

H1a: Information asymmetry increases around operational risk first announcements, especially immediately after the announcement.

H1b: Information asymmetry decreases around operational risk settlement announcements, especially immediately after the announcement.

We investigate whether the strength of corporate governance helps explain the changes in information asymmetry around operational risk announcements. The quality and quantity of information disclosed by the management is positively associated with the strength of corporate governance (Klein, 2002; Ajinkya, Bhojraj, and Sengupta, 2005; Karamanou and Vafeas, 2005). "Banks' disclosures should be consistent with how senior management and the board of directors assess and manage the risks of the bank." (BCBS, $2006 b$, p. 226) We consider the effects of external and internal governance.

The Basel II Capital Accord requires that senior management and the board of directors play a central role in operational risk management. Specifically, Pillar II mandates regular reporting of operational risk practices to senior management and the board of directors, and regular review of risk management systems and processes by internal and external auditors (BCBS, 2006b, pp. 149-151). Independent board directors balance the power of executive directors sitting on the board and monitor the performance and integrity of the senior management. They motivate the senior management to exert more effort to provide disclosure of higher quality and to improve internal controls thus reducing agency costs between owners and managers (Fama, 1980; Fama and Jensen, 1983; Walsh and Seward, 1990; Beasley, 1996; Beasley, Carcello, Hermanson, and Lapides, 2000; Klein, 2002; Farber, 2005). Therefore, we expect board independence to be negatively associated with information asymmetry around operational risk announcements - both first and settlements.

We examine the role of stock holdings by the firm's board directors. The agency theory theorizes a positive link between managerial ownership and disclosure quality. The extent of managerial ownership helps align the interests of management with those of shareholders (Jensen and Meckling, 1976). We therefore hypothesize that information asymmetry is lower around operational risk announcements for firms with higher levels of managerial stock ownership. ${ }^{7}$ We look also at the monitoring role played by blockholders. Because of their wealth being closely linked to the performance and market valuation of the disclosing firm, larger shareholders have stronger incentives to exert monitoring over the integrity and efficiency of management. This alleviates agency conflicts and enhances disclosure quality (Shleifer and Vishny, 1986; Huddart, 1993; Admati, Pfleiderer, and Zechner, 1994; Maug, 1998; Noe, 2002). Therefore,

\footnotetext{
${ }^{7}$ Recent empirical work frequently supports another, management entrenchment, theory that suggests a negative association between managerial ownership and disclosure quality. The theory postulates that concentrated managerial ownership could be counter-productive to the firm's long-term value, as management could effectively wield external monitoring. Strong equity incentive might cause management to focus too much on meeting certain stock price targets and maximizing their private benefits, while paying short attention to risk management controls or even reducing disclosure levels (Ruland, Tung, and George, 1990; Gelb, 2000; Eng and Mak, 2003; Nagar, Nanda, and Wysocki, 2003) and may lead to financial misreporting (Burns and Kedia, 2006; Efendi, Srivastava, and Swanson, 2007).
} 
market makers are expected to shrink the adverse selection component of the bid-ask spread for firms with large stakes in stock held by institutional owners. ${ }^{8}$

We proxy for external governance by the strength of shareholder rights. Weaker shareholder rights mean that the firm's management is more isolated from the external market for corporate control. Researchers have found a negative link between the strength of shareholder rights and the incidence of financial misstatements (Baber, Kang, Liang, and Zhu, 2009), reporting of internal control weaknesses (Elbannan, 2009), and operational risk exposure by financial firms (Chernobai, Jorion, and Yu, 2011). The management in firms with weak governance would show more discretion to follow its own agenda and would have diminished incentives to align their interests with those of shareholders. We therefore expect firms with stronger shareholder rights to make greater attempts at providing more credible information to investors, leading to lower information asymmetry around operational risk announcements. ${ }^{9}$

H2: Information asymmetry is lower around operational risk first and settlement announcements for firms with stronger internal and external governance.

Strong risk management function in financial firms is necessary in order to correctly identify risks and to prevent excessive risk-taking (Ellul and Yerramilli, 2013; Kashyap, Rajan, and Stein, 2008; Stulz, 2008). By adopting an enterprise risk management (ERM) system, companies attain a more systematic, topdown, approach toward risk management, which includes risk assessment, quantification, financing, and managing, and which in turn improves firm's operational and strategic decisions, leads to more efficient capital allocation, and increases the value of the organization (Grace, Leverty, Phillips, and Shimpi, 2014). Beasley, Pagach, and Warr (2008) and Liebenberg and Hoyt (2003) found that establishing of a Chief Risk Officer (CRO) position signals the adoption of an ERM system and the equity market reacts positively to such news in corporate firms. Hoyt and Liebenberg (2011) and Grace, Leverty, Phillips, and Shimpi (2014) found that ERM adds value to publicly traded insurance firms by increasing the cost and revenue efficiency. Baxter, Bedard, Hoitash, and Yezegel (2013) document increased usefulness and reliability of accounting information for financial firms with higher quality ERM. Since disclosure is a characteristic of a town-down risk management, transparency and quality of information regarding risk and operational efficiency available to market participants should improve. Therefore, we conjecture the

\footnotetext{
${ }^{8} \mathrm{~A}$ counter argument can be made but is not supported by our data. In the financial industry, the principal-agent relationship is not confined to the traditional relationship between managers and shareholders as found for industrial firms. Frequently, managers and large shareholders of financial firms experience more severe agency conflicts with minor shareholders, tax payers, and the society as a whole (Evans and Quigley, 1995; BCBS, 2006a). In the presence of deposit insurance, institutional investors may have incentives to undertake higher risks (Laeven and Levine, 2009; Ellul and Yerramilli, 2013). As a result, they may mitigate the disclosure incentives of managers in order to extract private benefits at the detriment of minor shareholders (Jensen and Meckling, 1976; John, Litov, and Leung, 2008; and Laeven and Levine, 2009), forcing the management to withhold information and dilute public disclosure. They start trading on private information prior to an announcement, thus driving up the trading volume. Market makers observe high trading volume and might suspect undisclosed information to be possessed by blockholders and anticipate higher information risk. As a result, to protect themselves against information risk, market makers may widen the bid-ask spread.

${ }^{9}$ Perry and de Fontnouvelle (2005) found a positive link between shareholder rights and the market reaction to operational risk announcements. They argued that an operational risk in a firm with strong governance constitutes an unanticipated surprise to investors, causing them to react strongly to such an announcement. Consequently, market makers might revise their previous assessment of information risk associated with trading the stocks of such firms.
} 
presence of risk management initiatives to be negatively associated with information asymmetry.

While in corporate firms improvements in risk management are driven by learning from bad experience and past losses, financial firms may have other incentives. In financial services firms risk management practices are significantly more mature than in corporate firms (Beasley, Branson, and Hancock, 2012; Pagach and Warr, 2011). Ellul and Yerramilli (2013) document an across-the-board increase in risk management initiatives in bank holding companies after 1999, and argue that banks frequently appoint risk managers merely to satisfy regulatory compliance, without giving them real power. Minton, Taillard, and Williamson (2014) report that in 2001, 4-5\% of all banks have a risk committee and CRO, and by $200713 \%$ of firms had a risk committee and $19 \%$ had the CRO position. ${ }^{10}$

Ellul and Yerramilli (2013) identify two channels through which risk management function may develop in financial firms. In the "business model channel" banks have an aggressive risk culture and choose to take higher risks coupled with weaker risk management functions. Financial firms are in the business of taking risks and they may optimally choose to undertake higher risks while at the same time tightening risk controls in addition to increasing hedging. In the "hedging channel" banks adopt a more aggressive stance on risk management when they experience financial distress. Beasley, Pagach, and Warr (2008) found no significant association between the equity market reaction and appointments of senior risk executives in financial firms. Minton, Taillard, and Williamson (2014) found that bank holding companies with a greater percentage of financial experts among independent directors engage in higher risk-taking activities because they have better understanding of more complex investments. Furthermore, they found that in stable times, the presence of external financial experts on the firm's board is associated with higher risk taking. Baxter, Bedard, Hoitash, and Yezegel (2013) too found no association of ERM quality with equity returns during the financial crisis (September 2008 through February 2009) in US financial services firms. In light of these considerations, we anticipate a dampened effect of risk management on information asymmetry.

We use several proxies for operational risk management: the presence of an Operational Risk Officer and his tenure; the existence of an operational risk committee and the number of years since its establishment; the presence of a Chief Risk Officer and his tenure; the existence of an enterprise-wide risk committee and the number of years since its establishment. Additionally, to capture the effectiveness of the board's risk oversight, we keep track if a firm's Chairman serves on the risk management committee. The above considerations motivate the following hypothesis.

H3: Information asymmetry is lower around operational risk first and settlement announcements for firms with stronger risk management functions.

\footnotetext{
${ }^{10}$ For comparison, in our sample of firms with operational risk announcements, 55\% of firms have an enterprise-wide risk committee and around $45 \%$ have a CRO position. These figures are substantial, given that they represent average proportions during the 1995-2009 period. However, our sample is biased toward larger firms and also risk management variable are significantly more prevalent in firms with above-median assets size. In past literature, firm size and business complexity have been shown to be positively associated with adoptions of an ERM system or appointments of a senior risk executive (Minton, Taillard, and Williamson, 2014; Gordon, Loeb, and Tseng, 2009; Hoyt and Liebenberg, 2011).
} 
Operational risk events come from diverse causes, and while some types, such as internal fraud and flawed business practices, are truly idiosyncratic and thus, arguably, more controllable from within the firm, others, such as external fraud, are externally originated (Chernobai, Jorion, and Yu, 2011). One would expect the announcements of internally inflicted events to represent the most significant amount of novel information revealed to the public. Perry and de Fontnouvelle (2005) and Gillet, Hübner, and Plunus (2010) found that internal fraud announcements cause the highest decline in the market value of loss firms. ${ }^{11}$ Gillet, Hübner, and Plunus (2010) also document a significant drop in equity values for events of type Clients, Products, and Business Practices. Cummins, Lewis, and Wei (2006) documented material leakage of information prior to operational risk announcements. Informed traders who possess superior knowledge about internal operations are likely to begin trading on such private information in the days leading to the announcement, thus increasing the information gap between informed and noninformed traders. We therefore hypothesize that information asymmetry is increased around operational risk first announcements especially for internal events. At the same time, because firms are more likely to implement controls in place to remediate such events and to make such actions publicly known, we anticipate no to little change in information asymmetry around the settlements. We thus hypothesize:

H4a: Increase in information asymmetry around operational risk first announcements is higher for internal fraud events and events related to flawed business practices.

H4b: Information asymmetry around operational risk settlement announcements is lower for internal fraud events and events related to flawed business practices.

The information content of an announcement may also shed light on how information asymmetry might change. The first characteristic is the disclosure source. We differentiate between events that are disclosed by the firm itself and events disclosed by a third party, such as a regulator, court, a customer, or a client firm. The benefits of self-disclosure of internal control deficiencies allow the management to "get in front of the issues" (Karr, 2005) and to signal to the market that the firm is free of more serious problems such as material weaknesses or a heightened likelihood of future earnings restatements (Martinek, 2005; Ashbaugh-Skaife, Collins, and Kinney, 2007). The positive message sent to the market serves as an assurance for the investors that the firm holds the quality of its financial information to a high standard. Therefore, one would anticipate a decrease in information asymmetry for self-disclosed events. In contrast, when an event is disclosed only by a third party, this raises red flags regarding potential serious problems with internal controls that the firm's management is trying to withhold. Third-party disclosure may deepen investors' concerns over the stability of the firm's future cash flows. Consequently, information asymmetry around third-party announcements should rise. ${ }^{12}$

\footnotetext{
${ }^{11}$ Perry and de Fontnouvelle (2005) found that internal fraud events cause market value drop that roughly 2 times exceeds the loss percentage (i.e., the loss amount divided by the market capitalization). Gillet, Hübner, and Plunus (2010) found that for operational risk announcements, trading volume begins to rise starting around day 4 prior to the press cutting date and the abnormal volume reaches roughly $25 \%$ on day -2 , almost $50 \%$ on day 0 , and $68 \%$ on day +1 .

${ }^{12} \mathrm{~A}$ counter-argument could be made, but is not supported by our data. Ashbaugh-Skaife, Collins, and Kinney (2007) studied voluntary disclosures of internal control deficiencies prior to SOX and found that the market shows no significance reaction to such announcements. Prior to SOX firms were likely selective in the information that they chose to disclose and
} 
Our second characteristic of an announcement is the information about the material impact that is disclosed. We consider quantifiable impact - the dollar amount of the loss. Gillet, Hübner, and Plunus (2010) found the negative equity market reaction to operational risk announcements to be stronger when the loss amount is unknown. Hirschey, Palmrose, and Scholz (2005) showed that the magnitude of a negative impact can be explained by the degree to which firms attempt to hide the extent of losses. When a loss amount is unknown at the first announcement, investors believe that important information about operational risk is intentionally left undisclosed, and uncertainty regarding the financial consequences for the firm rises. This should translate to greater information asymmetry. We believe this to be of relevance only for the first announcements because nearly all settlements incur a financial charge to the institution (see Table 2, Panel A). The preceding discussion motivates our last hypothesis:

H5: Information asymmetry is lower around operational risk announcements with greater information content-that are self-disclosed and that contain information on the loss impact. The second effect is relevant only for first announcements.

\section{Research Design}

\section{$5.1 \quad$ Variables}

We use our two proxies for information asymmetry - effective spread and price impact of trade - in level form (EFFECTIVE SPREAD and PRICE IMPACT) along with their differences from the non-event period ( $\triangle$ EFFECTIVE SPREAD and $\triangle$ PRICE IMPACT). The intra-day data on trades and quotes is from the Trade and Quote (TAQ) database. Following convention, we exclude quotes posted on regional exchanges. We use all NYSE, AMEX, and NASDAQ quotes posted between 9:30 AM and 4:00 PM EST for each trading day. As in Bessembinder (1999), we eliminate trades marked as exchange acquisitions or involving nonstandard settlement. ${ }^{13}$ We treat potential outliers by removing extreme trades involving price changes between two consecutive trades of over $50 \%$. We also drop all quotes with non-positive ask or bid price, quotes associated with trading halts or designated order imbalances, and quotes that are non-firm. ${ }^{14}$ Following convention, our event window spans 7 trading days, starting 3 trading days prior and ending three trading days after each announcement. As in Bhattacharya, Desai, and Venkataraman (2012), our non-event period spans the two weeks (10 trading days) commencing four calendar weeks prior to the announcement date and is used as a benchmark in constructing the $\Delta$-form variables. ${ }^{15}$

We use four variables related to corporate governance. We proxy for stronger boards using board independence (BOARD INDEPENDENCE), computed as the ratio of fully independent directors on the

\footnotetext{
voluntarily disclosed only what they believed to have no long-term impact on the firm. Hence, self-disclosed operational risk announcements may actually deepen investors' concern that there is more in stock to what has been revealed.

${ }^{13}$ TAQ database Sale Condition codes A, D, D, N, O, R, and Z.

${ }^{14}$ TAQ database Quote Condition codes 4, 7, 9, 11, 13, 14, 15, 19, 20, 27, and 28.

${ }^{15}$ Earlier studies have considered a non-event period of two trading days starting four weeks prior to the announcement date. An advantage of using a wider window is strengthening the validity of our benchmark quotes and trades. We tried using a two-day period for the non-event period but the results were weaker than using 10 trading days.
} 
board. We measure equity incentives of board directors by their ownership of company's shares (INSIDER OWNERSHIP), computed as the ratio of common shares owned by the insiders to all common shares outstanding. Because this variable is severely right-skewed, we winsorize it at $95 \%$. We also proxy for the effects of ownership concentration by the fraction of common shares owned by outside blockholders (BLOCK OWNERSHIP) holding over 5\% of firm's shares. Data on institutional ownership were collected from the Blockholders database for 1996-2001 and for the period 2001-2009 hand-collected from proxy statements. Gompers, Ishii, and Metrick (2003) governance index (GINDEX) is the number of antitakeover charter provisions and laws, ranging from 0 to 24 . Higher index values mean better insulation from the market for corporate control, and thus weaker shareholder rights. The data are from RiskMetrics.

The nine risk management variables were hand-collected from $10-\mathrm{K}$ and proxy filings. Five are dummy variables-OPRISK OFFICER, OPRISK COMMITTEE, CHIEF RISK OFFICER, RISK COMMIT$T E E$, and CHAIR ON RC. The other four are the number of years each risk management function has been in place-OPRISK OFFICER YEARS, OPRISK COMMITTEE YEARS, CHIEF RISK OFFICER YEARS, and RISK COMMITTEE YEARS. Table 7 provides further details on the risk positions and committees in our sample. Similarly to Ellul and Yerramilli (2013), we construct RISK MANAGEMENT $S C O R E$ by taking the first principal component of our nine risk management variables. Principal component analysis performs a singular value decomposition of the correlation matrix of the nine variables. We extracted the single factor that is the eigenvector in the decomposition with the highest eigenvalue. By constructing a risk management score in this way, the risk series that move more together are given more weight in the overall score, eliminating the need to subjectively judge on the relative importance of each risk factor. Higher values of the score suggest better ERM. ${ }^{16}$

We use several variables related to announcements characteristics. The first two are a dummy variable for self-disclosed events (DISCLOSED BY FIRM) and a dummy variable that flags whether the operational loss amount was revealed on the press cutting date (LOSS ANNOUNCED). We also distinguish between event types using Basel-defined event type classification described in Section 2. As explained earlier, we exclude all announcements related to Damage to Physical Assets due to their random nature. We include three dummy variables to capture the effects of internal fraud (INTERNAL FRAUD), events of type Clients, Products, and Business Practices (CLIENTS, PRODUCTS, \& BUSINESS PRACTICES), and external fraud (EXTERNAL FRAUD), and hold all other events as a reference group.

Our models include several control variables. NUMBER OF ANALYSTS is the number of analysts following the firm in the latest earnings per share forecast, collected from Thomson Reuters' Institutional Brokers' Estimate System (I/B/E/S) database. For firms with lower analyst coverage, information is transmitted more slowly across the investing public (Hong, Lim, and Stein, 2000) and investors are less certain about the firm's future performance (Lang and Lundholm, 1996; Abarbanell, Lanen, and

\footnotetext{
${ }^{16}$ Baxter, Bedard, Hoitash, and Yezegel (2013) use a different, analyst-based, measure of overall ERM quality. They use S\&P ERM quality rating that is based on S\&P analysts' evaluations (weak, adequate, strong, or excellent) of a financial firm's ERM, gathered from the 404 ERM disclosures in the S\&P Ratings Direct database. The data covers selected firms among banks and insurance companies.
} 
Verrecchia, 1995; Barron, Kim, Lim, and Stevens, 1998). Hence, market makers might anticipate higher information risk around operational risk announcements for firms with lower analyst coverage. In support of this view, Atiase and Bamber (1994) and Kanagaretnam, Lobo, and Whalen (2005) document higher abnormal bid-ask spread around corporate earnings announcements for firms that are less widely followed.

Drawing from past research on information asymmetry, we include firm size (FIRM SIZE) as a control, computed as the natural logarithm of a firm's total assets at the end of the previous quarter. Firms' total assets were extracted from Compustat. We also control for leverage (LEVERAGE). Empirical studies suggest that there may be an increase in volatility in the stock market prior to an earnings announcement because of speculative trades. As we discussed earlier, for operational risk announcements, any jump in volatility should suggest trades by informed investors trying to profit from private information. We thus include the variable VOLATILITY measured as the standard deviation of daily equity returns during the year ending one month prior to the announcement. We expect a positive coefficient because greater riskiness is translated into greater uncertainty regarding the future of the firm that may be known only to informed traders. While VOLATILITY captures idiosyncratic risk of the firm, we also include a measure of systematic risk, BETA, that is estimated as the beta factor estimated from single-factor CAPM model; we use 255 days of daily equity returns and the value-weighted market index. Market data are obtained from the University of Chicago's Center for Research in Security Prices (CRSP).

We control for stock performance using PRICE which is the trading price on the previous trading day for each day in the event window. We believe that market makers anticipate larger discrepancy in opinions between informed and liquidity traders for announcements that bring bigger surprises to the market, i.e., those accompanied by the greater drops in equity values. Easley and O'Hara (1992) showed that market makers widen the spreads in response to unusually high trading volumes. We thus include the logarithm of the trading volume (VOLUME) on the previous trading day for each event day as a control. The logarithm of the number of common shares outstanding (NUMBER OF SHARES) is used as an additional control variable in our model for liquidity determination.

Another control variable is DECIMAL that equals 1 for all events after January 29, 2001 and 0 otherwise. On this date, NYSE and AMEX moved from fractional pricing to decimal pricing, and NASDAQ mirrored the change on April 9, 2001. Bessembinder (2003) found that the reductions in tick size have led to a significant narrowing in spreads; in particular, trades executed outside the quotes saw the largest improvements in executions costs, thus making effective spread an event more efficient measure of information asymmetry than quoted spread. ${ }^{17}$ We also include dummy variables to distinguish between banks $(B A N K S)$ and insurance firms (INSURERS) from other financial firms, to account for possible industry differences in information asymmetry. In one of our robustness checks, we also include year fixed effects. Variables' description and data sources are summarized in Appendix.

\footnotetext{
${ }^{17}$ Bhattacharya, Desai, and Venkataraman (2012) eliminated all earnings announcements in 2001 to avoid problems due to having announcement and non-announcement periods in different tick size regimes. None of the events in our sample had event window and non-event period belong to the two different tick size regimes.
} 


\subsection{Econometric Framework}

Our data are organized as a balanced cross-sectional time-series panel. Each panel represents an individual event spanning seven trading days. Such research design was used in Lee, Mucklow, and Ready (1993), Libby, Mathieu, and Robb (2002), Verrecchia and Weber (2006), Werner (2004), Kanagaretnam, Lobo, and Whalen $(2005,2007)$, and Yohn (1998). ${ }^{18}$ The dependent variable is a measure of information asymmetry - effective spread or price impact of trade - and the independent variables consist of firmspecific governance and risk management covariates, event-specific announcement characteristics, and control variables. For each firm-event $i$ and trading day $t$ of the event window, we estimate the following Ordinary Least Squares (OLS) regression model separately for the first and settlement announcements:

$$
\begin{gathered}
(\Delta)_{\text {Information Asymmetry }} \text { At }=\alpha+\sum_{j=1}^{J} \gamma_{j} \text { Governance }_{i t, j}+\sum_{r=1}^{R} \psi_{r} \text { Risk Management }_{i t, r} \\
+\sum_{k=1}^{K} \beta_{k} \text { Announcement Charactistics }_{i t, k}+\sum_{m=1}^{M} \theta_{m} \text { Control Variables }{ }_{i t, m}+\varepsilon_{i t},
\end{gathered}
$$

where on the left hand side Information Asymmetry is EFFECTIVE SPREAD or PRICE IMPACT in level or change $(\Delta)$ form. On the right hand side, term $\alpha$ is the intercept, term Governance is the set of governance variables (BOARD INDEPENDENCE, INSIDER OWNERSHIP, BLOCK OWNERSHIP, and GINDEX), term Risk Management is either the RISK MANAGEMENT SCORE or the set of individual risk management variables (described in Section 5.1), term Announcement Characteristics is the set of variables related to announcement characteristics (DISCLOSED BY FIRM, LOSS ANNOUNCED, INTERNAL FRAUD, EXTERNAL FRAUD, and CLIENTS, PRODUCTS, E BUSINESS PRACTICES), term Control Variables is comprised of control variables (NUMBER OF ANALYSTS FIRM SIZE, VOLATILITY, LEVERAGE, BETA, ( $\Delta)$ PRICE, $(\Delta)$ VOLUME, and dummy variables $D E C I M A L, B A N K S$, and INSURERS), and the term $\varepsilon$ is the residual term. We account for potential heteroscedasticity by using heteroscedasticity-robust standard errors.

We estimate Equation (3) using announcement period $[-3,+3]^{19}$ but later differentiate between preand post-announcement periods by estimating the models for $[-3,-1]$ and $[0,+3]$ separately (Lee, Mucklow, and Ready, 1993; Libby, Mathieu, and Robb, 2002; Werner, 2004; Yohn, 1998). In the pre-announcement periods, information asymmetry measures the speed with which traders process the private information that may have leaked prior to each operational risk announcement. In the post-announcement periods, they capture the efficiency with which traders process the private information that has been disclosed. Over the full announcement period, information asymmetry reflects the net effect of the two.

\footnotetext{
${ }^{18}$ Other papers such as Affleck-Graves, Callahan, and Chipalkatti (2002), Chae (2005), Eleswarapu, Thompson, and Venkataraman (2004), and Krinsky and Lee (1996) used a cross-sectional research design with one observation per event.

${ }^{19}$ In a robustness check omitted for brevity we tried $[-1,+1]$ but obtained qualitatively similar results.
} 


\section{Empirical Results}

\subsection{Univariate Results}

Figure 3 illustrates effective spread and price impact of trade in the window surrounding the first and settlement announcement dates. Left column presents these variables in their level form, and right column presents their changes from the non-event period. Information asymmetry in the level form is positive on the interval, as expected, with a notable spike at day 0 with only a slow downward trend after the announcement for first announcements; for settlements, the highest levels of information asymmetry are on day -3. These patterns are more pronounced for price impact of trade and for the abnormal changes in the two variables. This is consistent with the view that effective spread is a noisier measure of the adverse selection component of information asymmetry, than price impact of trade.

We also distinguish between three versions of post-trade benchmark $\tau$ in the computation of price impact of trade (see Equation (2)) $-\tau=30,15$, and 5 minutes - depicted in Figures 3e and 3f. Around first announcements, the level of price impact is the highest immediately after a trade ( $\tau=5$ minutes), while for the change in price impact of trade the highest value is for $\tau=30$ minutes. A 30 minute horizon includes revisions of quotes after a longer interval of time and is likely to better capture the market makers' full adjustment of their quotes in response to abnormal sell or buy order flow. The 30 minutes horizon has been a common choice in literature (e.g., Bhattacharya, Desai, and Venkataraman, 2012; Bhattacharya, Ecker, Olsson, and Schipper, 2012; Venkataraman, 2001; and Bessembinder and Kaufman, 1997). ${ }^{20}$ All our subsequent empirical results will focus on the 30 minute interval.

Table 3 summarizes sample descriptive statistics of our explanatory variables. The average and median G-Index values are 9, the average ratio of independent board members is $72.3 \%$ around first announcements (and is $74.4 \%$ around settlements) which is similar to the median value, just under $5 \%$ of firm shares are held by insiders and roughly $7 \%$ by institutional stockholders on average. A typical firm in our sample has 17 to 18 analysts following. An average firm size is $\$ 228.7 \mathrm{bln}(\exp (12.34))$ suggesting that our sample is biased toward large firms perhaps because larger firms are more under the media radar. We do not see any notable skewness in our variables, and quantile-quantile plots revealed only a slight deviation from normality for most of our variables, thus mitigating concerns that our empirical findings may be driven by outliers in the data.

Table 4 reports on the average effective spread and price impact of trade for different types of events and two sub-periods, pre-announcement $[-3,-1]$ and post-announcement $[0,+3]$, in level form (Panel A) and in abnormal change form (Panel B), along with mean difference tests for different sub-samples according to our key explanatory variables' median values (Panel C). The results in Panel A reveal interesting patterns of information asymmetry around the announcements. As expected, information asymmetry (in level form) is statistically significant (at $1 \%$ level) in all instances. The level of information asymmetry tends to increase in the second sub-period around first announcements, while the opposite is observed

\footnotetext{
${ }^{20}$ Huang and Stoll (1996) report that results are robust to the choice of horizon from 5 minutes to 30 minutes.
} 
around the settlement announcements. These results are supported in Panel B that shows the changes in information asymmetry from the non-event period. We also note a striking difference in the levels of information asymmetry by event type. Across all cases, the level of information asymmetry is the highest around the first announcements of Clients, Products, and Business Practices events and second or third highest for internal fraud events. For the same events, there is a significant drop in price impact of trade from non-event period around the settlements for the former type of events, and no notable drop for the latter type perhaps because financial firms take serious measures to remediate their business practices after announcements of such failures and make their actions public, leaving little information that is available only to the informed traders. All in all, our results lend preliminary support to our hypotheses $\mathrm{H} 1 \mathrm{a}, \mathrm{H} 1 \mathrm{~b}$, and $\mathrm{H}_{4}$ that predicted an increase in information asymmetry around first announcements and a decrease around settlement announcements, especially for internally originated events.

Panel C of Table 4 provides preliminary insight into the associations between information asymmetry, governance and risk management, and event characteristics beyond event type, as per our hypotheses H2, H3, and H5. With regard to the strength of internal and external governance, the univariate results are mixed. For the level-form information asymmetry measures, the results for the first announcements consistent with our predictions are for GINDEX, DISCLOSED BY FIRM, and LOSS ANNOUNCED. For the information asymmetry measures in $\delta$-form, the only expected result is for BOARD INDEPEN$D E N C E$. As for the settlement announcements, because information asymmetry drops around settlement announcements (as was seen in Panel B of Table 4 and Figure 3), we expect firms with high ratios of board independence and insider ownership, high risk management scores, and events with loss amount disclosed in the settlement announcement to be associated with smaller drops in information asymmetry; Table 4 Panel C supports the aforementioned expectations only for the level form information asymmetry measures. All in all, this table partially supports our hypotheses.

We also examined Pearson's pairwise correlations between our variables; full table with results is omitted for brevity. Insider ownership appears to be strongly negatively associated (-0.33) with board independence (perhaps because firms with low independence ratios compensate for the weak internal governance by equity incentives for the executives), with number of analysts (-0.28), and with firm size (0.33). Firm size is also strongly positively correlated with the number of analysts following (0.36) because larger firms tend to be followed by a greater number of analysts. Firm size is positively correlated with the risk management score (0.49), which is expected based on our earlier discussion in Section 4. Apart from these, we do not see much problems with multicollinearity amongst our explanatory variables. Additionally, the Variance Inflation Factors (VIF) in our subsequent econometric models range from 1.03 to 3.48 per variable with an average VIF per model between 1.89 and 2.23 that are well within acceptable ranges (under 10), eliminating concerns over multicollinearity.

We must caution against overinterpreting the above results because they are univariate in nature and do not control for the impact of other important variables in our model. In what follows, we proceed to the multivariate analysis of information asymmetry around operational risk announcements. 


\subsection{Multivariate Results}

The results of our models (Equation (2)) are presented in Table 5. For each measure of information asymmetry - effective spread and price impact of trade - we use two versions of the dependent variable, in its level and change form. As such, we have four models for the first announcements and four models for the settlement announcements. The reported results use event window $t=[-3,+3]$.

With regard to internal and external governance, our findings support hypothesis H2. For the first announcements, the coefficient of BOARD INDEPENDENCE is negative and significant at $1 \%$ level for all four model specifications. To better see the economic significance of the result, an increase in this variable from its first quartile to its third quartile (63.64\% and $82.35 \%$, respectively, from Table 3 ) results in a predicted decrease in effective spread by $0.40 \%(18.72 \% \times 0.0212)$ and a decrease in $\Delta$-effective spread from non-event period by $0.43 \%$. Similarly, ceteris paribus, an increase in INSIDER OWNERSHIP from its first to its third quartile results in a predicted decrease in price impact of trade by $0.41 \%$ and a decrease in $\Delta$-price impact of trade by $0.17 \%$. With regard to institutional ownership concentration, $B L O C K$ OWNERSHIP enters our models with expected negative sign. All else equal, an increase in $B L O C K$ OWNERSHIP from its first to its third quartile is predicted to increase price impact by $0.99 \%$, a result statistically significant at the $1 \%$ level. GINDEX has a predicted positive coefficient (an exception is in $\triangle P R I C E$ IMPACT equation where the coefficient is negative but insignificant), but which is significant only in the level regressions. For an increase in G-Index from its first to its third quartile, a ceteris paribus predicted increase in effective spread is $0.41 \%$ and in price impact of trade is $1.39 \%$. These predicted effects are per single transaction and are economically significant when extrapolated over several trading days. Around the settlement announcements, the signs of the coefficients of these variables are reversed (with only two exceptions), as predicted by our hypothesis H2. This suggests that, overall, the reduction in information asymmetry is smaller for better governed firms.

With respect to risk management, we are unable to see that information asymmetry is lower around first announcements of operational risk events in firms with more established risk management systems. This is consistent with our discussion leading to hypothesis $H 3$ and suggests that risk management initiatives in financial firms are undertaken largely to meet regulatory requirements without carrying significant power, and their impact on the information disclosure quality is limited. The result is also consistent with Ellul and Yerramilli's (2013) "business model channel" for the development of risk management systems in financial firms. According to this channel, financial firms may optimally choose to undertake high risks while strengthening risk controls at the same time, a conjecture supported by past literature. As high business risks are associated with greater uncertainty in the equity markets, this should also widen information asymmetry between the informed and noninformed traders. For the settlement announcements, the coefficient of RISK MANAGEMENT SCORE is positive and significant (as we expected) for Model (8) ( $\Delta$ price impact of trade equation) and is negative and mildly significant in the other three model specifications, suggesting that transparency is higher for firms with more established risk management practices around the settlements. 
We find some evidence that, around first announcements, events due to internal fraud of flawed business practices are associated with greater levels and increases in information asymmetry. This results holds primarily in Models (3) and (4) (i.e., level and $\Delta$-price impact of trade equations), supporting our hypothesis $\mathrm{H}_{4} \mathrm{a}$. Our findings also indicate that around the settlement announcements information asymmetry drops for these events by a lesser extent than for other types of events, as we predicted in hypothesis $H_{4} b$. This is especially pronounced for events related to business practices.

The variable DISCLOSED BY FIRM has the predicted negative, although insignificant, sign for the first announcements only in Models (3) and (4). Evidently, both firms and investors benefit from such announcements being informative. Around settlement announcements, the coefficient is predicted positive and significant in three out of four models. We do not find strong evidence that when the loss amount is contained in the initial announcement it reduces information asymmetry. However, as is evident from Models (5)-(7), in anticipation of a settlement announcement, there is a smaller reduction in information asymmetry around settlement announcements if the loss amount is disclosed than when it is not disclosed, as expected. In sum, our results lend support to our hypothesis H5.

As for our control variables, the findings are mixed. FIRM SIZE, VOLATILITY, LEVERAGE, BETA, and $(\triangle) P R I C E$ enter most of our models with expected signs and statistically significant coefficients. We also find some evidence that around first announcements, information asymmetry is greater in insurance firms than in banks or other financial firms. We also find that decimalization has a surprisingly positive effect on information asymmetry. One possible explanation to this result is that post-decimalization period (2001-2009) in our sample overlaps with two periods of economic downturns - early 2000s and the credit crisis of 2008-2009. Since markets tend to exhibit greater volatility during economic recessions, it is likely that firms are more inclined to withhold private (negative) information from the public, thus widening the information gap between informed and non-informed traders. In a later section, we will perform a robustness check in which we exclude the problematic period post-August 2008. Interestingly, NUMBER OF ANALYSTS enters our regressions in Models (1)-(4) with an unexpected positive sign, which is statistically significant in three of the four models. Eleswarapu, Thompson, and Venkataraman (2004) note that companies may provide material information to analysts as a reward for obtaining favorable ratings and recommendations, who in return pass this information to large clients. Such selective disclosure leads to trading advantages of informed traders and can therefore contribute to the asymmetric information costs faced by non-informed traders.

We briefly comment on the goodness of fit. $R^{2}$ ranges from $14 \%$ to $30 \%$ in level regressions and from $4 \%$ to $8 \%$ in $\Delta$-regressions. In market microstructure papers, it is not uncommon to see low $R^{2}$ values. For example, in Bhattacharya, Desai, and Venkataraman (2012) $R^{2}$ is only around one to two percent. Similarly, in Kanagaretnam, Lobo, and Whalen (2007), $R^{2}$ is under $5 \%$. We also compare our models using AIC and BIC criteria. ${ }^{21}$ The preferred model is the one with lower AIC and BIC values. The

\footnotetext{
${ }^{21}$ Akaike Information Criterion (AIC) is computed as $A I C=2 k-2 \ln (L)$ where $k$ is the number of parameters estimated and $L$ is the likelihood value. AIC rewards goodness of fit and applies penalty for overfitting. Bayesian Information Criterion
} 
values of $\mathrm{AIC}$ and BIC coefficients generally drop when the dependent variables are taken in their change form, suggesting a better model. Also, although $R^{2}$ values are higher for level regressions, AIC and BIC values for the same models tend to be lower than for their counterparts in the $\Delta$-regressions.

In Table 6, we estimate our econometric models from Table 5 separately for two sub-periods of the event window: the pre-announcement period $[-3,-1]$ and the post-announcement period $[0,+3]$. As predicted in our hypotheses, the governance effects on information asymmetry have higher absolute values of the coefficients and are also more statistically significant in the post-announcement period, with the exception of G-Index. A similar pattern is evident with regard to announcement characteristics. All in all, our earlier results from Table 5 appear magnified for the post-announcement period for the first announcements, suggesting that not only does information asymmetry increase immediately following the announcement, but that this increase is also more strongly determined by the strength of governance and other variables. Likewise, for the settlement announcements, we observe from Panel B of Table 6 that the reduction in information asymmetry is moderated by stronger governance and higher information content of the press releases during the post-announcement period.

We note that our results in Tables 5 and 6 frequently varied depending on whether the dependent variable is taken in the level or difference form. When information asymmetry is taken in the level form, the coefficient may capture contemporaneous effects of the governance and other variables on the overall level of information asymmetry in the markets, and may not necessarily reflect their impact on information asymmetry around operational risk announcements. In this sense, when the dependent variable is in difference form (i.e., all even-numbered models in Table 5 and Models (3), (4), (7), and (8) in Table 6), we are better able to delineate the effects of our explanatory variables on the changes in information asymmetry around first and settlement announcements of operational risk events. In subsequent discussions we will focus on information asymmetry in its change form.

\subsection{Risk Management and Information Asymmetry}

In our previous models we used an aggregate risk management score variable for the effectiveness of the overall risk management system in a financial firm. In this section, we take a closer look at the individual components of operational risk management programs and enterprise-wide risk management system. To do so, we include in our models all of the nine risk management variables to examine the individual impact of each of them on the change in information asymmetry around operational risk announcements. We begin with describing in greater detail our risk management data.

Figure 4 illustrates the time series behavior of our firms' adoptions of various risk management

initiatives. It was not until 1999 that the first firm in our sample established an Operational Risk Committee and not until 2003 that the first firm appointed an Operational Risk Officer. As is summarized in Table 7, less than $8 \%$ of our firms have an Operational Risk Officer position established at the time of an operational risk first announcement, and this proportion increased by only around $3 \%$ by the time (BIC) is computed as $B I C=k \ln (n)-2 \ln (L)$ and accounts also for the sample size $n$. 
of settlement. Less than a quarter of firms have an Operational Risk Committee in place around the first announcement, and this proportion increased by $10 \%$ by the time of settlement. With regards to firm-wide risk committees and CROs, such initiatives began sooner. On the one hand, nearly half of our firms have the CRO position or a risk committee. On the other hand, other firms were slow with implementing similar risk management practices, as the proportions of firms with the CRO position or a risk committee remained practically unchanged by the time of settlement. These descriptive statistics echo Ellul and Yerramilli (2013) that document that even though there was an across-the-board increase in risk management initiatives after 1999, bank holding companies with high tail risk prior to 1999 did not experience greater increases in such initiatives than the bank holding companies with low tail risk.

Table 8 presents our multivariate results. Models (1) and (5) are replica of Models (4) and (8) from Table 5, respectively. We add three new model specifications. In Models (2) and (6) we include variables related to operational risk management: OPRISK OFFICER, the interaction term OPRISK OFFICER*OPRISK OFFICER YEARS, OPRISK COMMITTEE, and OPRISK COMMITTEE*OPRISK COMMITTEE YEARS. In Models (3) and (7) we include variables related to enterprise-wide risk management: CHIEF RISK OFFICER, the interaction term CHIEF RISK OFFICER*CHIEF RISK OFFICER YEARS, RISK COMMITTEE, RISK COMMITTEE*RISK COMMITTEE YEARS, and RISK COMMITTEE*CHAIR ON RISK COMMITTEE. ${ }^{22}$ Finally, in Models (4) and (8) we combine all risk management variables in one model.

Two results stand out. First, even after decomposing risk management score, we are unable to find strong evidence that better risk management helps reduce information asymmetry around operational risk first announcements. The results are more in line with our hypothesis around settlement announcements. Second, only the coefficients of senior risk officers (OPRISK OFFICER and CHIEF RISK OFFICER) enter our models consistently with expected signs - negative in the first announcement regressions and positive in the settlement regressions. There appears to be no consistent pattern for the interaction variables and risk committees-related variables. One possible explanation is that when firms hire a senior risk officer, they bring an expert with a great amount of technical expertise (Liebenberg and Hoyt, 2003; Thiessen, Hoyt, and Merkley, 2001) and a person who is frequently an outsider, ${ }^{23}$ that results in a shift in the risk culture within the firm. Senior risk officers are held accountable for ERM of the firm, report directly to the $\mathrm{CEO}$ or $\mathrm{CFO}$, and are responsible for communicating the firm's risk profile to external stakeholders. In contrast, risk-related committees typically constitute appointees from already existing board members, and so the risk management (and governance) leadership within the firm is effectively unchanged. Therefore, while senior risk officers oversee the risk identification and assessment process more effectively, establishments of risk committees seem little more than regulatory compliance.

\footnotetext{
${ }^{22}$ We did not include an interaction term between operational risk committee and Chairman serving on the committee, because in none of the firms in our sample was the Chairman serving on the committee.

${ }^{23}$ Thiessen, Hoyt, and Merkley (2001) report, based on a 2001 survey, that one third of all CROs were hired from outside of the organization. According to the survey, CROs identify operational risk management as one of their key responsibilities.
} 


\subsection{Robustness Checks}

In this section, we will test the robustness of our models using a series of robustness checks. Table 9 presents the results. Panel A summarizes the results for the first announcements and Panel B for the settlement announcements. In both panels the dependent variable is the abnormal change in price impact of trade. We use price impact of trade rather than effective spread because it is a less noisy measure of the adverse selection component of information asymmetry.

First, we previously used cross-section time-series panel models. Because many of our explanatory variables remain constant over the event window, there may be insufficient time-series variation in our explanatory variables overall. To address this concern, in our first robustness check (RC1) we use crosssectional average values of information asymmetry over the event window as our dependent variable. In particular, for each event announcement, we use only one observation. The dependent variable is the average measure of information asymmetry per transaction over the event window $[-3,+3]$, and the two explanatory control variables that varied on a daily basis in our earlier specification (PRICE and VOLUME) are similarly defined. Such research design was adopted in Eleswarapu, Thompson, and Venkataraman (2004), Bhattacharya, Desai, and Venkataraman (2012), Krinsky and Lee (1996), AffleckGraves, Callahan, and Chipalkatti (2002), and Chae (2005). For the first announcements (Panel A), the number of observations drops to 188 from 1,316 and for the settlements (Panel B) it drops to 288 from 2,014. The magnitudes of the coefficients are qualitatively unchanged, but the significance dropped for some variables. $R^{2}$ increased by about $11 \%$ in Panel A and $2 \%$ in Panel B.

Second, Bessembinder (2003) showed that firms on NYSE and NASDAQ exchanges experienced significant declines in tick size due to decimalization in 2001. In our original models we included a dummy variable $D E C I M A L$ to account for changes in information asymmetry due to decimalization but found an unexpected positive association. One plausible explanation is that the dummy variable overlaps with two economic recession periods in the U.S. since 2001: April 2001-November 2001 and January 2008-June 2009. ${ }^{24}$ While the former one was short, the latter one was more prolonged and more severe. Prior research has shown that stock returns become more volatile during recessions reflecting greater uncertainty in the markets. As a result, information asymmetry may experience an overall increase in the post-2001 era, which may explain our earlier results. In this robustness check we exclude the problematic post-credit crisis period starting August 2008, following earlier studies. Model (RC2) in Table 9 reports the results for this robustness check. The results resemble closely our original findings but are strengthened as is seen from the increased magnitudes of most coefficients. $R$-squared also improved slightly.

Third, we examine separately fraud events (RC3), events of type Clients, Products, \& Business Practices (RC4), and all other events (RC5). As is seen from Panel A in Table 9, institutional stockholders provide an incentive to financial firms to disclose higher quality information regarding Clients, Products, \& Business Practices type events that are closely linked to firms' business practices, but not fraud or

\footnotetext{
${ }^{24}$ Source: the National Bureau of Economic Research (NBER), http://research.stlouisfed.org/fred2/series/USREC.
} 
other events. However, price impact of trade is most likely to decline when firms disclose fraud events. Then, around settlement announcements, firms with more independent boards and with boards with high insider ownership are the ones experiencing the lowest drops in adverse selection for internal fraud and business practices-related events, because such governance structures equip firms with better incentives to disclose high quality information to all market participants.

In the fourth robustness check (RC6), we include year fixed effects to account for any omitted macroeconomic variables that may change over the sample period. Most of the year dummy variables came out insignificant (coefficients are omitted for brevity). Other results remain robust for the most part and are economically unchanged.

Fifth, some of our results may be tainted by operational risk announcements that were made as part of scheduled earnings announcement, restatements, or reported in SEC filings. To address this concern, we carry out robustness check (RC7), in which we drop 21 such first announcements and 13 such settlement announcements and re-estimate our main model. The results are qualitatively the same.

In the sixth, final robustness check, we redefined our RISK MANAGEMENT SCORE variable. Instead of performing a principal component decomposition of the correlation matrix of the risk factors, we created an additive version of the risk management score by giving a score of one for the presence of each of the following operational risk and broader firm-wide risk management initiatives: existence of the Operational Risk Officer position (OPRISK OFFICER), existence of the Operational Risk Committee (OPRISK COMMITTEE), existence of Chief Risk Officer position (CHIEF RISK OFFICER), existence of a risk committee (RISK COMMITTEE), and the Chairman of the board serving on the risk committee (RISK COMMITTEE*CHAIR ON RISK COMMITTEE). The results are depicted in Model (RC8) in Table 9 . The coefficients and their significance levels remain robust to this model specification.

\section{$7 \quad$ Market Liquidity and Bid-Ask Spread}

Information asymmetry around operational risk announcements may affect liquidity. Past studies have used two measures of stock market liquidity: quoted depth and trading volume. Gillet, Hübner, and Plunus (2010) documented that abnormal trading volume increases by $68 \%$ following operational risk announcements in U.S. financial firms. Chae (2005) compared liquidity for scheduled and unscheduled news announcements. He showed that informed traders begin trading the stock more actively prior to an announcement, while uninformed discretionary liquidity traders are unwilling to trade prior to the announcement because price sensitivity to order flow is high. In his empirical results, trading volume decreases by over $15 \%$ prior to scheduled earnings announcements but increases for unscheduled announcements. In our sample, abnormal change in trading volume is positive around first announcements (unscheduled) and is negative around settlement announcements (anticipated); see Table 3. To the contrary, Kim and Verrecchia (1994) argue that the increase in trading volume generated by informed traders more than offsets the decrease in trading volume by discretionary liquidity traders, and so the overall 
increase in trading volume prior to an earnings announcement is solely driven by informed trading. In either case, we expect that the increase in trading volume prior to operational risk first and settlement announcements should be overwhelmingly attributed to informed traders.

In this section, we take a closer look at market liquidity surrounding operational risk announcements. Quoted depth is the quantity limit set by the market maker and is measured as the sum of number of shares available at bid and at ask. Past empirical studies have looked at how market makers use quoted depth as a strategic tool to hedge against information asymmetry and how the bid-ask spread and quoted depth interact. Dupont (2000) and Kavajecz (1998) showed that market makers may use spreads and depths as substitutes when faced with information asymmetry. ${ }^{25}$ Earlier studies have maintained that bid-ask spread and depth are simultaneously determined (Kavajecz, 1998, 1999; Dupont, 2000; Libby, Mathieu, and Robb, 2002; Kanagaretnam, Lobo, and Whalen, 2005, 2007; Lee, Mucklow, and Ready, 1993). Specifically, around earnings announcements abnormal quoted depth decreases in information asymmetry; Lee, Mucklow, and Ready (1993) showed that wider spreads are accompanied by lower depths, but depths return to normal levels shortly (within half an hour) following the news release.

Following earlier studies (e.g., Lee, Mucklow, and Ready, 1993; Kavajecz, 1999; Dupont, 2000; Libby, Mathieu, and Robb, 2002; Hedge and Miller, 1989; and Kanagaretnam, Lobo, and Whalen, 2005, 2007), we model quoted depth simultaneously with our two measures of information asymmetry — effective spread and price impact of trade - in their change forms, using a system of equations. As such, we augment these earlier studies that use quoted bid-ask spread as a measure of information asymmetry. Simultaneous modeling allows to correct for correlations between the error terms. In each system of two equations, the first equation estimates $\triangle$ QUOTED DEPTH and the second equation estimates either $\triangle E F F E C T I V E$ SPREAD or $\triangle$ PRICE IMPACT. Following prior empirical research, in the depth equation we include an appropriate measure of information asymmetry along with additional control variables - NUMBER OF SHARES and $\triangle$ VOLUME. In the information asymmetry equation, we include $\triangle$ QUOTED DEPTH along with other variables included in our models described in the previous sections, but omit $\triangle V O L$ $U M E$. The simultaneous equations model is specified as follows: ${ }^{26}$

$$
\begin{array}{r}
\Delta \text { QUOTED DEPTH }_{i t}=\alpha+\xi \Delta \text { Information Asymmetry }_{i t}+\sum_{j=1}^{J} \gamma_{j} \text { Governance }_{i t, j} \\
+\sum_{r=1}^{R} \psi_{r} \text { Risk Management }_{i t, r}+\sum_{k=1}^{K} \beta_{k} \text { Announcement Charactistics }_{i t, k}+\sum_{m=1}^{M} \theta_{m} \text { controls }_{i t, m}+\varepsilon_{i t}
\end{array}
$$

\footnotetext{
${ }^{25}$ Easley and O'Hara (1992) developed a theoretical model explaining the negative association between abnormal trading volume prior to an announcement and market depth immediately following an announcement. In their model, market makers exploit trading volume to uncover the existence of informed traders: if market makers note abnormal trading volume, they suspect higher informed trading and react by widening the bid-ask spread and reducing the quoted depth. In this study we do not find empirical support to this view: the association between abnormal levels of quoted depth and trading volume is positive and significant at the $1 \%$ level, when all other factors are accounted for.

${ }^{26}$ Studies that considered trading volume as an alternative measure of liquidity have also used a system of a equations to simultaneously model spread and volume. See for example, Affleck-Graves, Callahan, and Chipalkatti (2002), Glosten and Harris (1988), and Hedge and Miller (1989).
} 
and

$$
\begin{array}{r}
\Delta \text { Information Asymmetry }_{i t}=\alpha^{\prime}+\xi^{\prime} \Delta \text { QUOTED DEPTH }_{i t}+\sum_{j=1}^{J} \gamma_{j}^{\prime} \text { Governance }_{i t, j} \\
+\sum_{r=1}^{R} \psi_{r}^{\prime} \text { Risk Management }_{i t, r}+\sum_{k=1}^{K} \beta_{k}^{\prime} \text { Announcement Charactistics }_{i t, k}+\sum_{m=1}^{M^{\prime}} \theta_{m}^{\prime} \text { controls }_{i t, m}+\varepsilon_{i t} .
\end{array}
$$

The results are presented in Table 10. In the information asymmetry equations, the coefficients' signs are for the most part consistent with our earlier models that used price impact of trade. Consistent with earlier studies, we find that market makers use quoted depth and spread as substitutes to deal with information risk of facing informed traders. This is evident from the coefficients of appropriate measures of information asymmetry in the depth equations (all odd-numbered models) and the coefficients of quoted depth in the spread equations (all even-numbered models) being negative and statistically significant at levels 1-5\% (with only one exception in Models (3) and (4)).

As expected, quoted depth increases in trading volume. The coefficient of $\triangle$ VOLUME is positive and significant at $1 \%$ level in all four depth equations. For banks and insurers, quoted depth is higher than for other financial firms, which may be explained by elevated trading volume during the event period. Interestingly, NUMBER OF ANALYSTS enters the depth models with an expected positive sign, although the coefficient is statistically insignificant. Analyst forecasts are more accurate for firms that have a great number of analysts following, resulting in narrower spreads (supported in our Models (6) and (8) in this table) and more generous depths set by the market makers.

\section{Conclusion}

Recent regulatory initiatives call for greater market transparency in the public disclosure of financial information. An example is the Basel Capital Accord that lays out a set of standards for financial institutions regarding the quantification, management, and disclosure of operational risk. Other initiatives that address disclosure include the Gramm-Leach-Bliley Act (GLBA) of 1999, the Health Insurance Portability and Accountability Act (HIPAA) of 1996, the Sarbanes-Oxley Act (SOX) of 2002, and the Dodd-Frank Act of 2010. Recent empirical research has shown that public announcements of operational risk events are value-relevant, as market values of firms experience statistically significant drops. This paper takes that stream of research one step further and explores the ways in which market makers react to changes in information asymmetry caused by unscheduled operational risk announcements, and then by their settlement announcements. In our analysis, effective bid-ask spread and price impact of trade

serve as proxies for information asymmetry. Using 15 years of data from public U.S. financial firms, we find evidence of a substantial increase in information asymmetry around first press-cutting dates of operational risk events and a decrease in information asymmetry around their settlement announcements. Our empirical results are robust to various model specifications. 
We examined the role of internal and external governance and risk management on information asymmetry. We found that stronger governance structure reduces information asymmetry around operational risk event announcements. Specifically, around the first announcements effective spread and price impact of trade are significantly negatively associated with board independence ratio, equity incentives, and institutional ownership, and are significantly positively associated with G-Index. Similarly, around the settlement announcements strong governance leads to smaller drops in information asymmetry. This result offers compelling evidence that stronger governance structure reduces information asymmetry between the informed and non-informed traders. We also examined the effects of the strength of the risk management function, proxied for by the existence of Chief Risk Officer, Chief Operational Risk Officer, operational risk committee, enterprise-wide risk committee, and the number of years each of these had been in place, and found that only the presence (or appointments) of senior risk officers have an impact on information asymmetry, while risk-related committees do not. We interpret this as evidence that the risk management function is largely driven by the regulatory compliance needs and has only a limited impact on the level of information asymmetry between firms and investors. Alternatively, this can be explained by the "business model channel," in which financial firms with an aggressive risk culture may optimally choose to undertake high risks while tightening their risk controls.

The increase in information asymmetry around first announcements is higher for internal fraudrelated events or those linked to weak business practices. This result agrees with similar findings for earnings announcements in prior studies. This finding is particularly intriguing given that, unlike earnings announcements that are scheduled, first announcements of operational risk are unscheduled. Therefore, much of the abnormal trading should be attributed to informed traders while the noise trading by liquidity traders is minimal. For the same internal events, we found that the drop in information asymmetry around the settlement announcements is smaller than for other types of operational risk events. We believe this is because firms choose to provide the public with more accurate and value-relevant information regarding the remediation actions and new policies to resolve the issues, in order to avoid bad publicity and adverse reputational consequences, which in turn reduces adverse selection.

This is the first empirical study to examine information asymmetry around operational risk announcements. Our empirical findings also revealed that trading volume experiences a substantial increase around operational risk first announcements and that quoted depth is negatively associated with information asymmetry, showing an overall improvement in liquidity. This information might be useful for regulators in establishing more effective operational risk disclosure requirements for financial firms. Further theoretical and empirical research is necessary to investigate the determinants of liquidity and explain market makers' decisions to increase quoted depth and the underlying drivers of elevated abnormal trading volume around such announcements. Answering these questions would contribute to our understanding of the liquidity consequences of public disclosures of fraud and other operational risk events. Another avenue worth exploring is comparison of information asymmetry around operational risk announcements between non-financial corporations, banks, insurers, and other financial firms. A preliminary analysis 
suggests that there are differences in the levels and determinants of information asymmetry even within the financial sub-industries. For example, information asymmetry around the first announcements of operational risk events is better explained by the strength of internal and external governance for insurers and non-banks, than for depository institutions, a result that may be attributable to greater disclosure requirements for banks and differences in the governance structures. We leave this important research question to future investigation.

\section{References}

Abarbanell, J., Lanen, W., Verrecchia, R., 1995. Analysts' forecasts as proxies for investor beliefs in empirical research. Journal of Accounting and Economics 20(1), 31-60.

Admati, A., Pfleiderer, P., Zechner, J., 1994. Large shareholder activism, risk sharing, and financial market equilibrium. Journal of Political Economy 102(6), 1097-1130.

Affleck-Graves, J., Callahan, C., Chipalkatti, N., 2002. Earnings predictability, information asymmetry, and market liquidity. Journal of Accounting Research 40(3), 561-583.

Ajinkya, B.B., Bhojraj, S., Sengupta, P., 2005. The association between outside directors, institutional investors and the properties of management earnings forecasts. Journal of Accounting Research 43(3), 343-376.

Anderson, K., Yohn, T., 2002. The effect of 10-K restatements on firm value, informatin asymmetries and investors' reliance on earnings. Working paper, Georgetown University.

Ashbaugh-Skaife, H., Collins. D.W., Kinney Jr., W.R., 2007. The discovery and reporting of internal control deficiencies prior to SOX-mandated audits. Journal of Accounting and Economics 44(1/2), 166-192.

Atiase, R.K., Bamber, L., 1994. Trading volume reactions to annual accounting earnings announcements: The incremental role of predisclosure information asymmetry. Journal of Accounting and Economics 17(3), 309-329.

Baber, W., Kang, S., Liang, L., Zhu, Z., 2009. Shareholder rights, corporate governance and accounting restatement. Working paper, George Washington University.

Barron, O., Kim, O., Lim, S., Stevens, D., 1998. Using analysts' forecasts to measure properties of analysts' information environment. Accounting Review 73(4), 421-434.

Basel Committee on Banking Supervision, 2006a. Enhancing corporate governance for banking organisations. Bank for International Settlements, Basel, Switzerland.

Basel Committee on Banking Supervision, 2006b. International convergence of capital measurement and capital standards. Bank for International Settlements, Basel, Switzerland.

Baxter, R., Bedard, J.C., Hoitash, R., Yezegel, A., 2013. Enterprise risk management program quality: Determinants, value relevance, and the financial crisis. Contemporary Accounting Research 30(4), 1264-1295.

Beasley, M.S., 1996. An empirical analysis of the relation between the board of director composition and financial statement fraud. Accounting Review 71(4), 443-465.

Beasley, M.S., Branson, B., Hancock, B., 2012. Report on the Current State of Enterprise Risk Oversight. ERM Initiative at North Carolina State University, Raleigh, NC. 
Beasley, M.S., Carcello, J.V., Hermanson, D.R., Lapides, P.D., 2000. Fraudulent financial reporting: Consideration of industry traits and corporate governance mechanisms. Accounting Horizons 14(4), 441-454.

Beasley, M.S., Pagach, D., Warr, R., 2008. Information conveyed in hiring announcements of senior executives overseeing enterprise-wide risk management processes. Journal of Accounting, Auditing and Finance 23(3), 311-332.

Bessembinder, H., 1999. Trade execution costs on NASDAQ and the NYSE: A post reform comparison. Journal of Financial and Quantitative Analysis 34, 387-407.

Bessembinder, H., 2003. Issues in assessing trade execution costs. Journal of Financial Markets 6(3), 233-257.

Bessembinder, H., Kaufman, H., 1997. A comparison of trade execution costs for NYSE and NASDAQ listed stocks. Journal of Financial and Quantitative Analysis 32(3), 287-310.

Bhattacharya, N., Desai, H., Venkataraman, K., 2012. Does earnings quality affect information asymmetry? Evidence from trading costs. Contemporary Accounting Research, forthcoming.

Bhattacharya, N., Ecker, F., Olsson, P.M., Schipper, K., 2012. Direct and mediated associations among earnings quality, information asymmetry, and the cost of equity. Accounting Review 87(2), 449-482.

Brooks, R.M., Patel, A., Su, T., 2003. How the equity market responds to unanticipated events. Journal of Business 76(1), 109-133.

Brown, S., Hillegeist, S.A., Lo, K., 2009. The effect of earnings surprises on information asymmetry. Journal of Accounting and Economics 47, 208-225.

Burns, N., Kedia, S., 2006. The impact of performance-based compensation on misreporting. Journal of Financial Economics 79, 35-67..

Chae, J., 2005. Trading volume, information asymmetry, and timing information. Journal of Finance $60(1), 413-442$.

Chernobai, A., Jorion, P., Yu, F., 2011. The determinants of operational risk in U.S. financial institutions. Journal of Financial and Quantitative Analysis 46(6), 1683-1725.

Chung, K.H., Elder, J., Kim, J., 2010. Corporate governance and liquidity. Journal of Financial and Quantitative Analysis 45(2), 265-291.

Copeland, T., Galai, D., 1983. Information effects on the bid-ask spread. Journal of Finance 38(5), 1457-1469.

Cummins, J., Lewis, C., Wei, R., 2006. The market value impact of operational loss events for US banks and insurers. Journal of Banking and Finance 30(10), 2605-2634.

Diamond, D., 1985. Optimal release of information by firms. Journal of Finance 40(4), 1071-1094.

Dupont, D.Y., 2000. Market making, prices and quantity limits. Review of Financial Studies 13(4), 11291151.

Easley, D., O'Hara, M., 1992. Time and the process of security price adjustment. Journal of Finance $47(2), 577-605$.

Efendi, J., Srivastava, A., Swanson, E.P., 2007. Why do corporate managers misstate financial statements? The role of option compensaion and other factors. Journal of Financial Economics 85, 667-708.

Elbannan, M., 2009. Quality of internal control over financial reporting, corporate governance, and credit ratings. International Journal of Disclosure and Governance 6(2), 127-149.

Eleswarapu, V.R., Thompson, R., and Venkataraman, K., 2009. The impact of regulation fair disclosure: Trading costs and information asymmetry. Journal of Financial and Quantitative Analysis 39(2), 209-225. 
Ellis, K., Michaely, R., O'Hara, M., 2000. The accuracy of trade classification rules: Evidence from NASDAQ. Journal of Financial and Quantitative Analysis 35, 529-551.

Ellul, A., Yerramilli, V., 2013. Stronger risk controls, lower risk: Evidence from U.S. bank holding companies. Journal of Finance 68(5), 1757-1803.

Eng, L., Mak, Y., 2003. Corporate governance and voluntary disclosure. Journal of Accounting and Public Policy 22(4), 325-345.

Evans, L., Quigley, N., 1995. Shareholder liability regimes, principal-agent relationships, and banking industry performance. Journal of Law and Economics 38(2), 497-520.

Fahlenbrach, R., Prilmeier, R., Stulz, R.M., 2012. This time is the same: Using bank performance in 1998 to explain bank performance during the recent financial crisis. Journal of Finance 67, 2139-2185.

Fama, E., 1980. Agency problems and the theory of the firm. Journal of Political Economy 88(2), 288-307.

Fama, E., Jensen, M., 1983. Separation of ownership and control. Journal of Law and Economics 26(2), 301-325.

Farber, D., 2005. Restoring trust after fraud: Does corporate governance matter? Accounting Review 80(2), 539-561.

Fu, R., Kraft, A., Zhang, H., 2012. Financial reporting frequency, information asymmetry, and the cost of equity. Journal of Accounting and Economics, forthcoming.

Gelb, D.S., 2000. Managerial ownership and accounting disclosure: An empirical study. Review of Quantitative Finance and Accounting 15(2), 169-185.

Gillet, R., Hübner, G., Plunus, S., 2010. Operational risk and reputation in the financial industry. Journal of Banking and Finance 34(1), 224-235.

Glosten, L.R., 1987. Components of the bid-ask spread and the statistical properties of transaction prices. Journal of Finance 42(5), 1293-1307.

Glosten, L.R., Harris, L.E., 1988. Estimating the components of the bid-ask spread. Journal of Financial Economics 21(1), 123-142.

Glosten, L.R., Milgrom, P., 1985. Bid, ask, and transaction prices in a specialist market with heterogeneously informed traders. Journal of Financial Economics 14(1), 71-100.

Gompers, P., Ishii, J., Metrick, A., 2003. Corporate governance and equity prices. Quarterly Journal of Economics 118(1), 107-155.

Gordon, L.A., Loeb, M.P., Tseng, C.-Y., 2009. Enterprise risk management and firm performance: A contingency perspective. Journal of Accounting and Public Policy 28, 301-327.

Grace, M.F., Leverty, J.T., Phillips, R.D., Shimpi, P., 2014. The value of investing in enterprise risk management. Journal of Risk and Insurance, forthcoming.

Grossman, S.J., Miller, M.H., 1988. Liquidity and market structure. Journal of Finance 43(3), 617-633.

Harris, M., Raviv, A., 1993. Differences of opinion make a horse race. Review of Financial Studies 6(3), 473-506.

Hasbrouck, J., 1988. Trades, quotes, inventories and information. Journal of Financial Economics 22(2), 229-252.

Hedge, S., Miller, R., 1989. Market-making in initial public offerings of common stocks: An empirical analysis. Journal of Financial and Quantitative Analysis 24, 75-90.

Hirschey, M., Palmrose, Z.V., Scholz, S., 2005. Long-term market underreaction to accounting restatements. Working paper, University of Kansas.

Ho, T., Stoll, H.R., 1981. Optimal dealer pricing under transactions and return uncertainty. Journal of Financial Economics 9(1), 47-73. 
Ho, T., Stoll, H.R., 1983. The dynamics of dealer markets under competition. Journal of Finance 38(4), 1053-1074.

Hong, H., Lim, T., Stein, J.C., 2000. Bad news travels slowly: Size, analyst coverage and the profitability of momentum strategies. Journal of Finance 55(1), 265-295.

Hoyt, R.E., Liebenberg, A.P., 2011. The value of enterprise risk management. Journal of Risk and Insurance $78,795-822$.

Huang, R.D., Stoll, H.R., 1996. Dealer versus auction markets. Journal of Financial Economics 41, $313-$ 357.

Huddart, S., 1993. The effect of a large shareholder on corporate value. Management Science 39(4), 1407-1421.

Jensen, M.C., Meckling, W.H., 1976. Theory of the firm: Management behaviour, agency costs, and ownership structure. Journal of Financial Economics 3(3), 305-360.

John, K., Litov, L., Yeung, B., 2008. Corporate governance and managerial risk taking: Theory and evidence. Journal of Finance 63(4), 1679-1728.

Kanagaretnam, K., Lobo, G., Whalen, D., 2005. Relationship between analyst forecast properties and equity bid-ask spreads and depths around quarterly earnings announcements. Journal of Business Finance and Accounting 32(9/10), 1773-1799.

Kanagaretnam, K., Lobo, G., Whalen, D., 2007. Does corporate governance reduce information asymmetry around quarterly earnings announcements? Journal of Accounting and Public Policy 26(4), 497-522.

Karamanou, I., Vafeas, N., 2005. The association between corporate boards, audit committees, and management earnings forecasts: An empirical analysis. Journal of Accounting Research 43(3), 453486.

Kashyap, A.K., Rajan, R.G., Stein, J.C., 2008. Rethinking capital regulation. Working paper, Federal Reserve Bank of Kansas City.

Kavajecz, K.A., 1998. A specialist's quoted depth as a strategic choice variable. Working paper, University of Pennsylvania.

Kavajecz, K.A., 1999. A specialist's quoted depth and the limit order book. Journal of Finance 54(2), 747-771.

Kim, O., Verrecchia, R., 1994. Market liquidity and volume around earnings announcements. Journal of Accounting and Economics 17(1/2), 41-67.

Klein, A., 2002. Audit committee, board of director characteristics, and earnings management. Journal of Accounting and Economics 33(3), 375-400.

Krinsky, I., Lee, J., 1996. Earnings announcements and components of the bid-ask spread. Journal of Finance 51(4), 1523-1535.

Laeven, L., Levine, R., 2009. Bank governance, regulation and risk taking. Journal of Financial Economics 93(2), 259-275.

Lang, M.H., Lundholm, R.J., 1996. Corporate disclosure policy and analyst behavior. Accounting Review 71(4), 467-492.

Lee, C.M.C., 1993. Market integration and price execution for NYSE-listed securities. Journal of Finance 48(3), 1009-1038.

Lee, C.M.C., Mucklow, B., Ready, M., 1993. Spreads, depths, and the impact of earnings information: An intraday analysis. Review of Financial Studies 6(2), 345-374.

Lee, C.M.C., Ready, M., 1991. Inferring trade direction from intraday data. Journal of Finance 46, 733-746. 
Libby, T., Mathieu, R., Robb, S., 2002. Earnings announcements and information asymmetry: An intraday analysis. Contemporary Accounting Research 19(3), 449-472.

Liebenberg, A.P., Hoyt, R.E., 2003. The determinants of enterprise risk management: Evidence from the appointment of Chief Risk Officers. Risk Management and Insurance Review 6(1), 37-52.

Martinek, P., 2005. SOX 'Catch 22:' Certifying controls later found weak. Compliance Week, February 22 .

Maug, E., 1998. Large shareholders as monitors: Is there a trade-off between liquidity and control? Journal of Finance 53(1), 65-98.

Minton, B.A., Taillard, J.P., Williamson, R., 2014. Financial expertise of the board, risk taking and performance: Evidence from bank holding companies. Journal of Financial and Quantitative Analysis, forthcoming.

Nagar, V., Nanda, D., Wysocki, P., 2003. Discretionary disclosure and stock-based incentives. Journal of Accounting and Economics 34(1-3), 283-309.

Noe, T., 2002. Institutional activism and financial market structure. Review of Financial Studies 15(1), 289-319.

Obizhaeva, A., 2008. The study of price impace and effective spread. Working paper, University of Maryland.

Pagach, D., Warr, R., 2011. The characteristics of firms that hire Chief Executive Officers. Journal of Risk and Insurance 78, 185-211.

Palmrose, Z., Richardson, V., Scholz, S., 2004. Determinants of market reactions to earnings restatements. Journal of Accounting and Economics 37, 59-90.

Perry, J., de Fontnouvelle, P., 2005. Measuring reputational risk: The market reaction to operational loss announcements. Working paper, Federal Reserve Bank of Boston.

Rosenberg, J.V., Schuermann, T., 2006. A general approach to integrated risk management with skewed, fat-tailed risks. Journal of Financial Economics 79(3), 569-614.

Ruland, W., Tung, S., George, N., 1990. Factors associated with the disclosure of managers' forecasts. Accounting Review 65(3), 710-721.

Shleifer, A., Vishny, R.W., 1986. Large shareholders and corporate control. Journal of Political Economy 94(3), 461-488.

Stoll, H.R., 1978. The pricing of security dealer services: An empirical study of NASDAQ stocks. Journal of Finance 33(4), 1153-1172.

Stoll, H.R., 1989. Inferring the components of the bid-ask spread: Theory and empirical tests. Journal of Finance 44(1), 115-134.

Stoll, H.R., 2000. Friction. Journal of Finance 55(4), 1479-1514.

Stulz, R.M., 2008. Risk management failures: What are they and when do they happen? Journal of Applied Corporate Finance 20, 58-67.

Thiessen, K., Hoyt, R.E., Merkley, B.M., 2001. A composite sketch of a Chief Risk Officer. The Conference Board of Canada, September 2001.

Venkataraman, K., 2001. Automated versus floor trading: An analysis of execution costs on the Paris and New York exchanges. Journal of Finance 56(4), 1445-1485.

Walsh J., Seward, J., 1990. On the efficiency of internal and external corporate control mechanisms. Academy of Management Review 15(3), 421-458.

Wang, T., Hsu, C., 2013. Board composition and operational risk events of financial institutions. Journal of Banking and Finance 37, 2042-2051.

Yohn, T.L., 1998. Information asymmetry around earnings announcements. Review of Quantitative Finance and Accounting 11, 165-182. 


\section{Appendix: Description of Variables}

The following table summarizes the variables used in this study and their definitions. All dollar denominated variables are measured in 2009 UDFA. All continuous variables except GINDEX and FIRM SIZE are winsorized at $1 \%$ and $99 \%$. The event window spans 7 trading days beginning 3 trading days prior to the announcement date and ending 3 trading days after. The non-event period spans 10 trading days (two weeks) commencing two calendar weeks prior to the announcement date.

\begin{tabular}{ll}
\hline Variable & Definition \\
\hline Information Asymmetry and Market Liquidity: & Source \\
\hline EFFECTIVE SPREAD & $\begin{array}{l}\text { Daily average effective spread per transaction. Effective spread (ES) for time } t \text { is TAQ } \\
\text { computed as (Lee, 1993; Huang and Stoll, 1996): }\end{array}$
\end{tabular}

$$
E S_{t}=2 \times D_{t} \times \frac{\text { Price }_{t}-\text { Midpoint }_{t}}{\text { Midpoint }_{t}} \times 100 \text {, where Price } \text { is the transaction price }
$$

at time $t$ and Midpoint $t_{t}$ is the midpoint of the quoted ask and bid prices immediately prior to the transaction. The factor $D_{t}$ equals 1 for market buy orders and -1 for market sell orders, and factor 2 accounts for the round trip cost of transaction. Measurement units: Percent.

$\triangle$ EFFECTIVE SPREAD Average effective spread on event day minus average effective spread in non-event TAQ period. Measurement units: Percent.

PRICE IMPACT Daily average price impact of trade per transaction. Price impact of trade (PIT) for TAQ time $t$ is computed as (Huang and Stoll, 1996):

$$
\text { PIT }_{t}=2 \times D_{t} \times \frac{\text { Price }_{t+\tau}-\text { Midpoint }_{t}}{\text { Midpoint }_{t}} \times 100 \text {, where Price } t+\tau \text { is the first }
$$

transaction price at least $\tau$ minutes after the transaction at time $t$, with $\tau$ taking values 5,15 , or 30 minutes, and Midpoint $t_{t}$ is the midpoint of the quoted ask and bid prices immediately prior to the transaction. The factor $D_{t}$ equals 1 for market buy orders and -1 for market sell orders, and factor 2 accounts for the round trip cost of transaction. Measurement units: Percent.
$\triangle$ PRICE IMPACT
Average price impact of trade on event day minus average price impact of trade in TAQ non-event period. Measurement units: Percent.
QUOTED DEPTH Natural logarithm of average quoted depth per transaction on the trading day. TAQ Measurement units: In (number of shares).
$\triangle$ QUOTED DEPTH Natural logarithm of average quoted depth per transaction on the trading day during TAQ event window minus natural logarithm of average quoted depth per transaction in non-event period. Measurement units: $\ln$ (number of shares).

Corporate Governance:

BOARD INDEPENDENCE

Ratio of independent board directors on the board at the end of previous year. RiskMetrics, Measurement units: Percent.

INSIDER OWNERSHIP Proportion of shares held by all executive and non-executive directors at the end of Proxy filings previous year. Measurement units: Percent.

BLOCK OWNERSHIP Proportion of shares held by outside blockholders at the end of previous year. Proxy filings Measurement units: Percent.

GINDEX

Gompers, Ishii, and Metrick's (2003) governance index (G-index) at the end of RiskMetrics previous year. It is an additive index constructed by giving one point to each of the 22 firm-level antitakeover provisions and 6 state antitakeover laws, with a total of 24 unique provisions. Higher index values indicate weaker investor protection. Measurement units: Whole number between 0 and 24.

Announcement Characteristics:
INTERNAL FRAUD
EXTERNAL FRAUD
CLIENTS, PRODUCTS, \& BUSINESS PRACTICES
DISCLOSED BY FIRM

\section{LOSS ANNOUNCED}

\section{1 if the event is of internal fraud type; 0 otherwise.}

1 if the event is of external fraud type; 0 otherwise.

1 if the event is of type Clients, Products, \& Business Practices; 0 otherwise.

1 if the event is self-disclosed by the firm; 0 if the announcement is made by a third Algo FIRST, party, such as a client, court order, or the SEC. We considered an event self-disclosed LexisNexis, Factiva if an announcement by a third party is accompanied by a statement by the firm on the same trading day. This variable is determined separately for first announcements and settlement announcements.

1 if the announcement discloses loss amount; 0 otherwise. This variable is Algo FIRST, determined separately for first announcements and settlement announcements.
Algo FIRST, LexisNexis, Factiva Algo FIRST, LexisNexis, Factiva Algo FIRST,
LexisNexis, Factiva LexisNexis, Factiva 
Proxy, 10-K

filings

OPRISK OFFICER YEARS

Number of years since establishment of the Operational Risk Officer position.

OPRISK COMMITTEE

1 if the firm has an operational risk committee; 0 otherwise.

Proxy, $10-\mathrm{K}$

filings

Proxy, 10-K

filings

Number of years since establishment of the operational risk committee.

Proxy, 10-K

filings

1 if the firm has a Chief/Senior Risk Officer position; 0 otherwise.

Proxy, 10-K

filings

Proxy, 10-K

filings

Proxy, 10-K

filings

Proxy, 10-K

filings

Proxy, 10-K

filings

CHAIR ON RC

1 if the Board Chairman is sitting on the risk committee; 0 otherwise.

The first principal component of the nine risk management variables, obtained via a Constructed by singular value decomposition of the correlation matrix of risk management authors categories. The single factor is the eigenvector with the highest eigenvalue.

Control Variables:

NUMBER OF ANALYSTS

FIRM SIZE

VOLATILITY

LEVERAGE

BETA

PRICE

$\triangle$ PRICE

NUMBER OF SHARES

VOLUME

$\triangle$ VOLUME

DECIMAL

BANKS

INSURERS
Number of analyst forecasts included in the I/B/E/S consensus earnings per share I/B/E/S forecast immediately prior to announcement.

Natural logarithm of total assets reported at the end of the last quarter before the Compustat announcement. Measurement units: In (USD million).

Standard deviation of the daily stock returns including dividends during the calendar CRSP year ending one month prior to announcement. Measurement units: Percent.

Leverage ratio computed by dividing total debt by total assets at the end of the last Compustat quarter before the announcement. Measurement units: Decimal.

A measure of firm's systematic risk. Estimated as the beta factor from single-factor CRSP CAPM model. We use 255 days of daily equity returns and the value-weighted market index.

Average trading price on previous trading day. Measurement units: USD.

TAQ

(Average trading price on previous trading day divided by average trading price in TAQ non-event period) minus one. Measurement units: Percent.

Natural logarithm of the number of common shares outstanding on the previous CRSP trading day prior to the announcement date. Measurement units: In (thousand of shares).

Natural logarithm of trading volume amount on the previous trading day. TAQ Measurement units: In (number of shares).

Natural logarithm of trading volume on previous trading day minus natural logarithm TAQ of average daily trading volume in non-event period. Measurement units: $\ln$ (number of shares).

1 if the announcement is made after decimalization of tick size (January 29, 2001); 0 Algo FIRST, otherwise. LexisNexis, Factiva

1 if the two-digit U.S. Standard Industry Classification (SIC) code is 60 (depository Proxy filings institutions); 0 otherwise.

1 if the two-digit U.S. Standard Industry Classification (SIC) code is 63 or 64 Proxy filings (insurance); 0 otherwise. 
Table 1: Sample Selection

This table describes our data screening procedure.

Data Screening Description

Number of Events

1. Announcements in U.S. public financial firms with loss $>\$ 10 \mathrm{mln}$ during $1980-2009 *$

- announcements during 1980-1994

2. Announcements in U.S. public financial firms with loss $>\$ 10 \mathrm{mln}$ during $1995-2009$

- announcements with unclear first press cutting date or company name

- announcements of events of type Damage to Physical Assets

$-85$

- announcements with missing trades and quotes data, stock price $<\$ 1,<5$ trades per day

$-94$

3. Final sample:

Events with both the first announcement and settlement announcement

Events with only the first announcement

Events with only the settlement announcement

121

*The data were extracted from the FIRST database at the end of 2009. Settlement dates for two events (as seen in Figure 1) were later updated and are shown to be in 2010 and 2013.

\section{Figure 1: Time Series Plot of Operational Risk Announcements}

This figure illustrates the time series of the number of operational risk announcements in our sample.

First Announcements and Settlement Announcements by Year

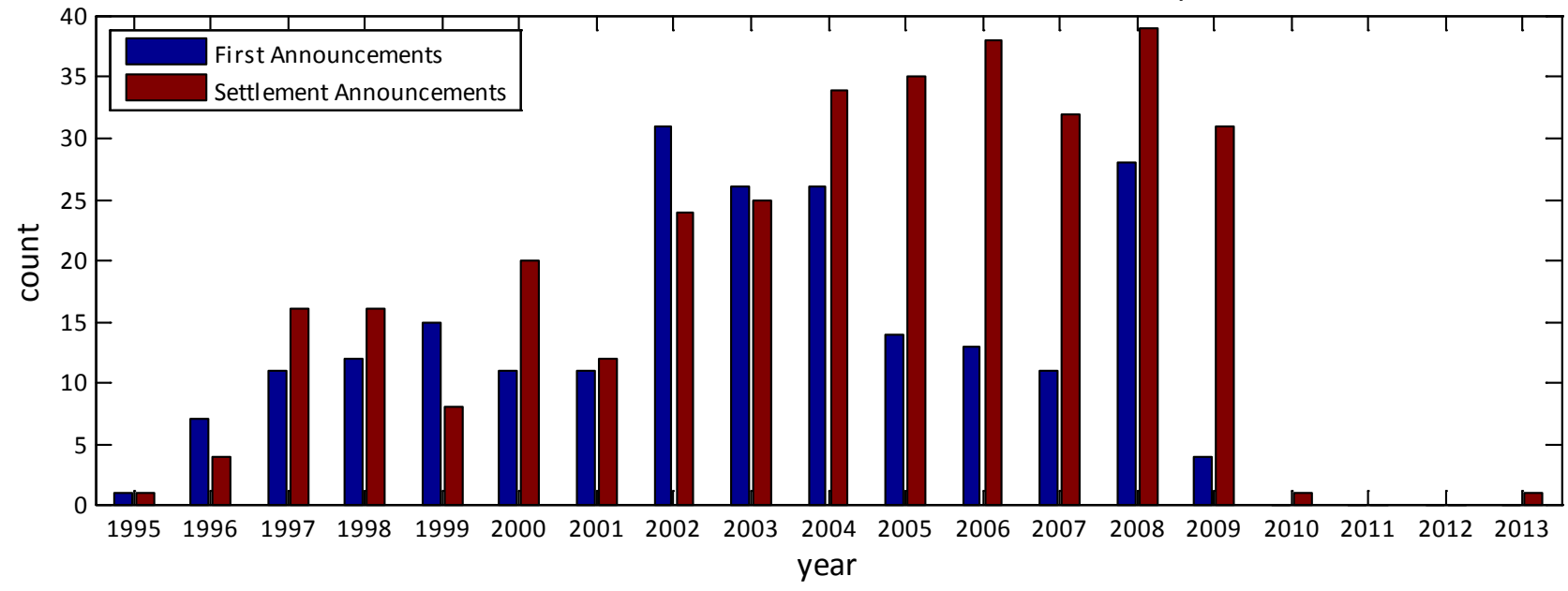


Figure 2: Abnormal Equity Returns around Operational Risk Announcements

This figure illustrates average cumulative abnormal returns for our sample data. A market model with equalweighted market index was first used to estimate equity returns over 255 trading days ending 60 days prior to the announcement. Then, abnormal returns were computed as the difference between daily equity returns during the event period surrounding an announcement and the predicted returns based on the market model, and averaged across all events.

Panel A: First announcements

Cumulative abnormal returns (\%) around first announcements

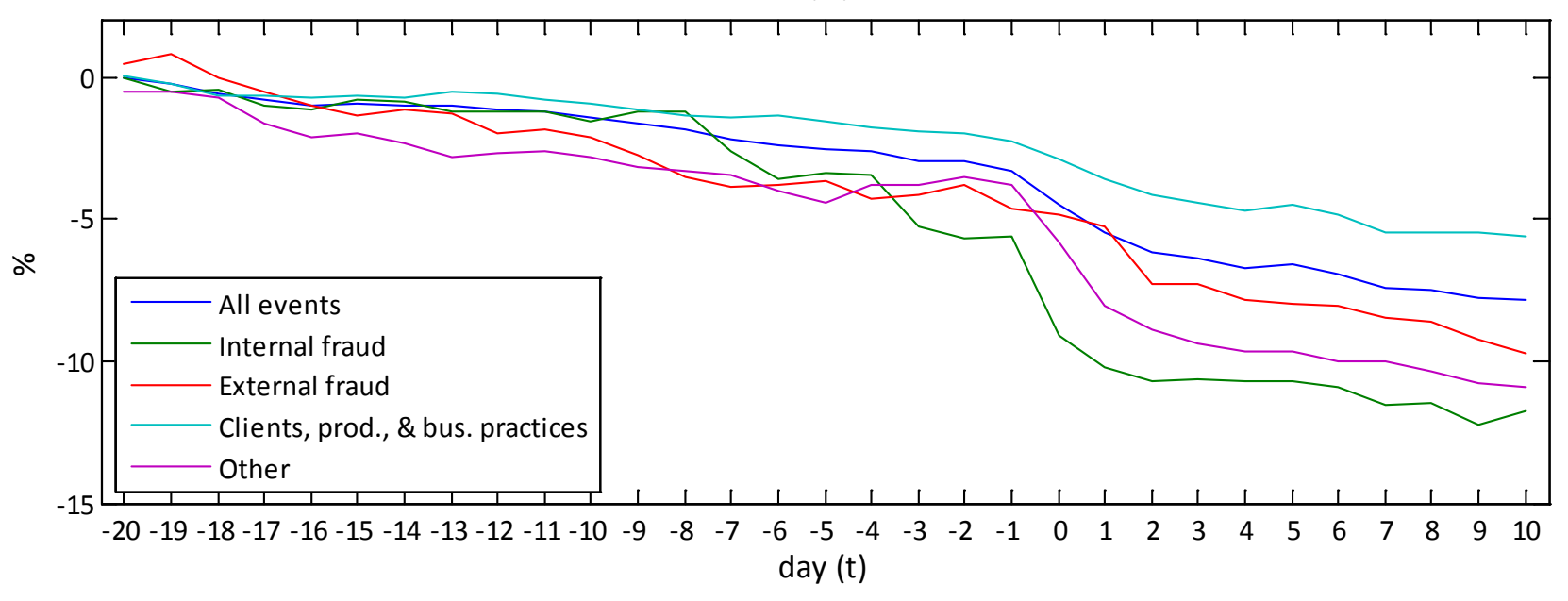

Panel B: Settlement announcements

Cumulative abnormal returns (\%) around settlement announcements

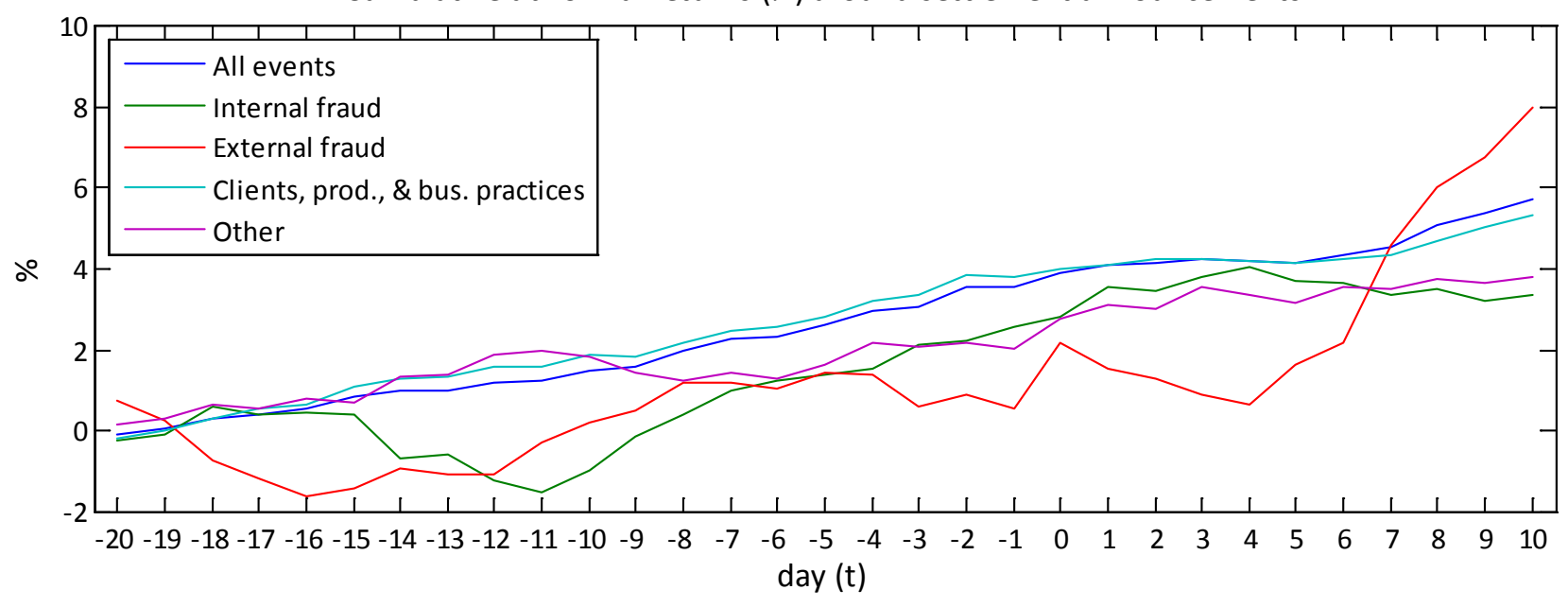


Table 2: Announcements Characteristics

This table summarizes the characteristics of operational risk event announcements.

Panel A: Distribution of announcements by disclosure source and loss amount

\begin{tabular}{|c|c|c|c|c|c|c|}
\hline \multirow{2}{*}{ Event Type } & \multicolumn{2}{|c|}{ Disclosure Source } & \multicolumn{2}{|c|}{ Loss Amount } & \multirow[t]{2}{*}{ Total } & \\
\hline & Self-Disclosed & Third Party & Disclosed & Not Disclosed & & \\
\hline \multicolumn{7}{|l|}{ First Announcements: } \\
\hline Internal Fraud & 16 & 15 & 25 & 6 & 31 & $(15.8 \%)$ \\
\hline External Fraud & 12 & 14 & 21 & 5 & 26 & $(13.3 \%)$ \\
\hline Employment Practices and Workplace Safety & 0 & 11 & 4 & 7 & 11 & $(5.6 \%)$ \\
\hline Clients, Products, and Business Practices & 25 & 88 & 50 & 63 & 113 & $(57.7 \%)$ \\
\hline Business Disruption and System Failures & 2 & 2 & 2 & 2 & 4 & $(2.0 \%)$ \\
\hline Execution, Delivery, \& Process Management & 4 & 7 & 7 & 4 & 11 & $(5.6 \%)$ \\
\hline All First Announcements & $\begin{array}{c}59 \\
(30.1 \%)\end{array}$ & $\begin{array}{c}137 \\
(69.9 \%)\end{array}$ & $\begin{array}{c}109 \\
(55.6 \%)\end{array}$ & $\begin{array}{c}87 \\
(44.4 \%)\end{array}$ & $\begin{array}{c}196 \\
(100 \%)\end{array}$ & $(100 \%)$ \\
\hline \multicolumn{7}{|l|}{ Settlement Announcements: } \\
\hline Internal Fraud & 19 & 19 & 36 & 2 & 38 & $(12.8 \%)$ \\
\hline External Fraud & 8 & 13 & 20 & 1 & 21 & $(7.0 \%)$ \\
\hline Employment Practices and Workplace Safety & 10 & 3 & 13 & 0 & 13 & $(4.4 \%)$ \\
\hline Clients, Products, and Business Practices & 106 & 99 & 202 & 3 & 205 & $(68.8 \%)$ \\
\hline Business Disruption and System Failures & 2 & 1 & 3 & 0 & 3 & $(1.0 \%)$ \\
\hline Execution, Delivery, \& Process Management & 12 & 6 & 18 & 0 & 18 & $(6.0 \%)$ \\
\hline All Settlement Announcements & $\begin{array}{c}157 \\
(52.7 \%) \\
\end{array}$ & $\begin{array}{c}141 \\
(47.3 \%)\end{array}$ & $\begin{array}{c}292 \\
(98.0 \%)\end{array}$ & $\begin{array}{c}6 \\
(2.0 \%)\end{array}$ & $\begin{array}{c}298 \\
(100 \%)\end{array}$ & $(100 \%)$ \\
\hline
\end{tabular}

Panel B: Distribution of announcements by SIC industry code

\begin{tabular}{|c|c|c|c|c|c|c|c|}
\hline Event Type & $\begin{array}{c}\text { 60xx } \\
\text { Depository } \\
\text { Institutions }\end{array}$ & $\begin{array}{c}\text { 61xx } \\
\text { Non- } \\
\text { Depository } \\
\text { Institutions }\end{array}$ & $\begin{array}{c}62 x x \\
\text { Security \& } \\
\text { Commodity } \\
\text { Brokers } \\
\end{array}$ & $\begin{array}{c}63 x x, 64 x x \\
\text { Insurance }\end{array}$ & $\begin{array}{c}\text { 65xx } \\
\text { Real Estate }\end{array}$ & Total & \\
\hline Internal Fraud & 17 & 3 & 20 & 7 & 0 & 47 & $(14.2 \%)$ \\
\hline External Fraud & 21 & 4 & 5 & 2 & 0 & 32 & $(9.7 \%)$ \\
\hline Employment Practices and Workplace Safety & 1 & 4 & 9 & 1 & 0 & 15 & $(4.5 \%)$ \\
\hline Clients, Products, and Business Practices & 58 & 24 & 68 & 61 & 0 & 211 & $(63.7 \%)$ \\
\hline Business Disruption and System Failures & 2 & 0 & 1 & 1 & 0 & 4 & $(1.2 \%)$ \\
\hline Execution, Delivery, and Process Management & 10 & 1 & 7 & 3 & 1 & 22 & $(6.7 \%)$ \\
\hline All Announcements & $\begin{array}{c}109 \\
(32.9 \%)\end{array}$ & $\begin{array}{c}36 \\
(10.9 \%)\end{array}$ & $\begin{array}{c}110 \\
(33.2 \%)\end{array}$ & $\begin{array}{c}75 \\
(22.7 \%)\end{array}$ & $\begin{array}{c}1 \\
(0.3 \%)\end{array}$ & $\begin{array}{c}331 \\
(100 \%)\end{array}$ & $(100 \%)$ \\
\hline
\end{tabular}


Figure 3: Illustration of Information Asymmetry

This figure illustrates the time series of daily average measures of information asymmetry around the event window $t=[-3,+3]$ for our sample data, in their level form (left) and in abnormal change form (right).

a) Effective spread (\%)

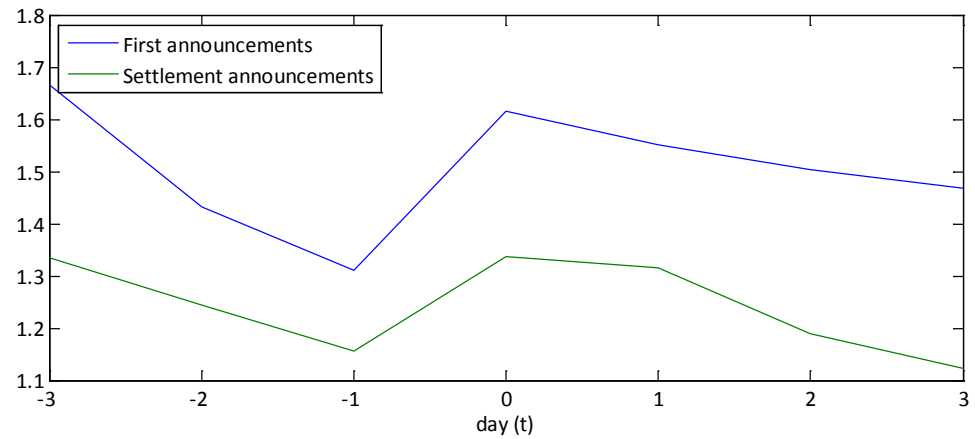

c) Price impact of trade (\%), $30 \mathrm{~min}$

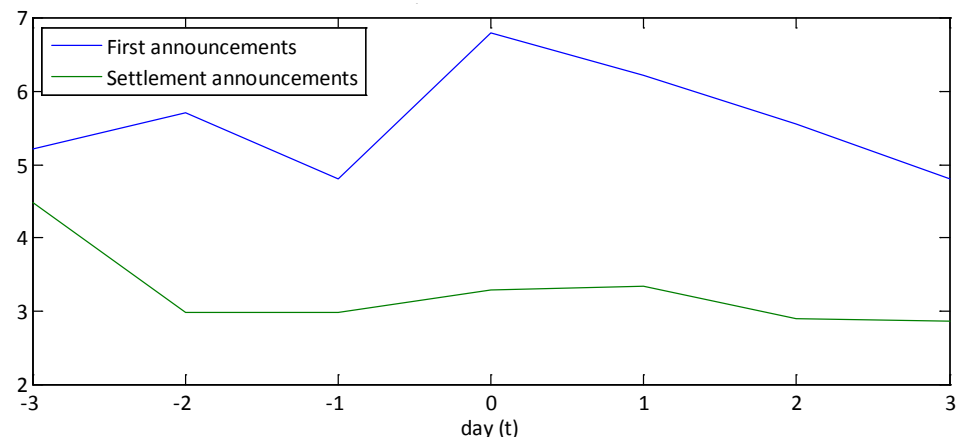

e) Price impact of trade (\%), 30, 15, $5 \mathrm{~min}$

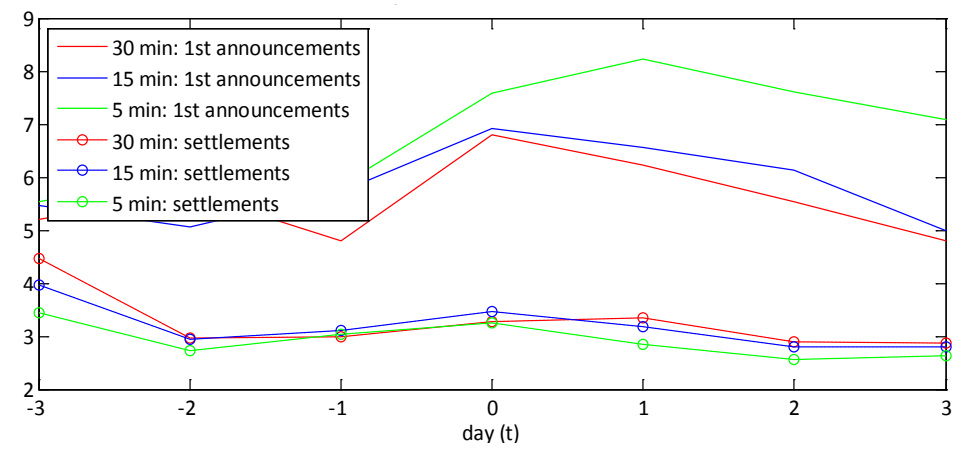

b) Change in effective spread (\%)

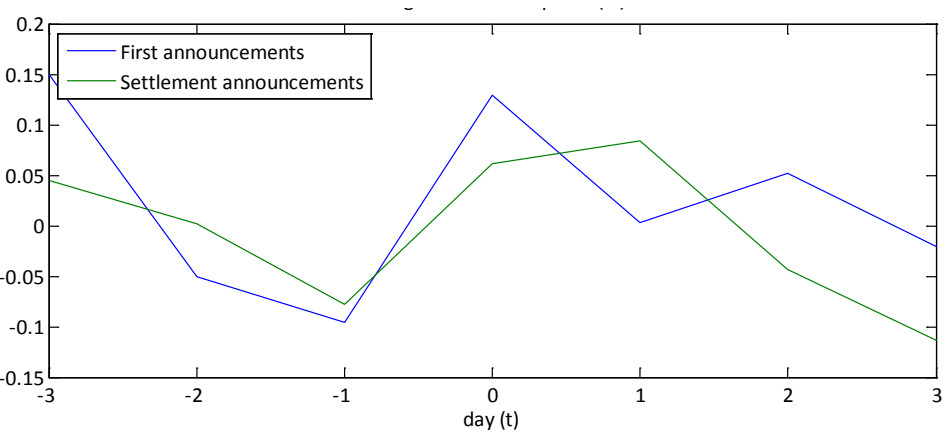

d) Change in price impact of trade (\%), $30 \mathrm{~min}$

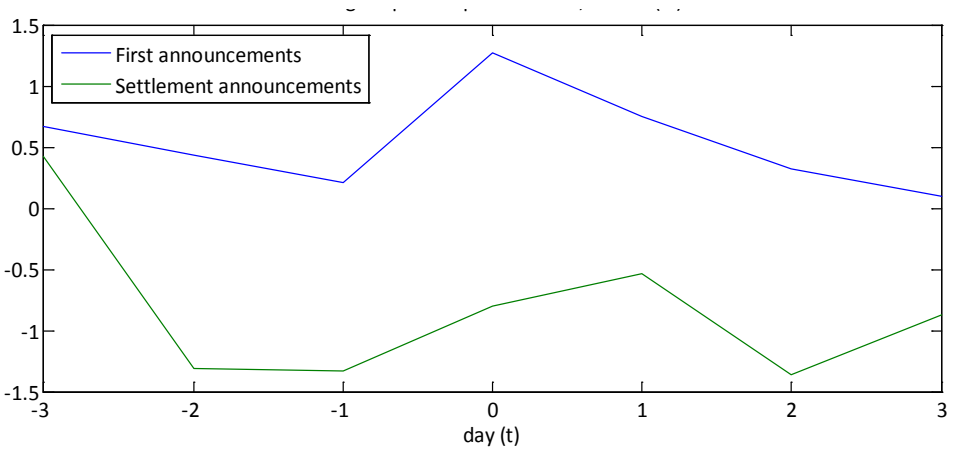

f) Change in price impact of trade (\%), 30, 15, $5 \mathrm{~min}$

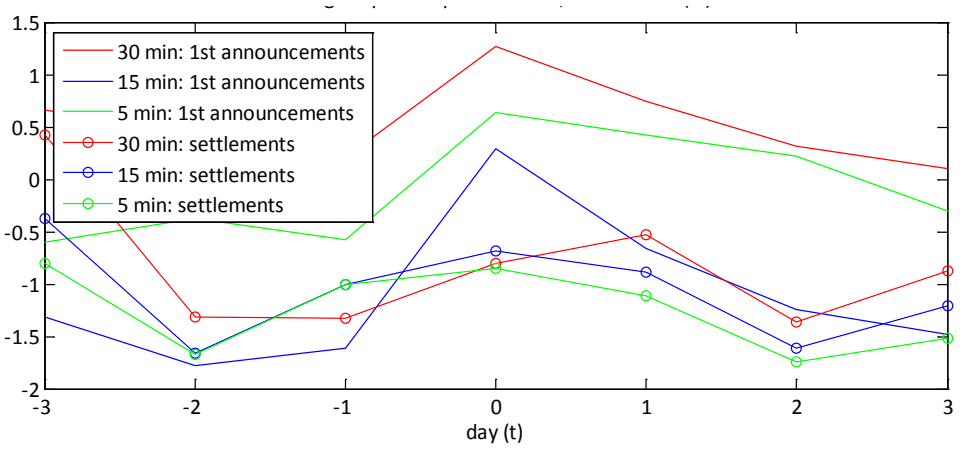


Table 3: Sample Descriptive Statistics

This table provides descriptive statistics for the characteristics of the firms in our data sample around the announcements for the event window $t=[-3,+3]$.

\begin{tabular}{|c|c|c|c|c|c|c|c|c|c|}
\hline Variable & $\begin{array}{l}\text { Announce- } \\
\text { ment }\end{array}$ & $\begin{array}{l}\text { Num. } \\
\text { Obs. }\end{array}$ & Mean & $\begin{array}{l}\text { St. } \\
\text { Dev. }\end{array}$ & $\begin{array}{l}5^{\text {th }} \\
\text { perc. }\end{array}$ & $\begin{array}{l}25^{\text {th }} \\
\text { Perc. }\end{array}$ & $\begin{array}{l}50^{\text {th }} \\
\text { Perc. }\end{array}$ & $\begin{array}{l}75^{\text {th }} \\
\text { Perc. }\end{array}$ & $\begin{array}{l}95^{\text {th }} \\
\text { Perc. }\end{array}$ \\
\hline \multicolumn{10}{|c|}{ Governance \& Risk Management: } \\
\hline \multirow[t]{2}{*}{ BOARD INDEPENDENCE } & First ann. & 1,477 & 72.341 & 13.538 & 50.000 & 63.636 & 75.000 & 82.353 & 90.910 \\
\hline & Settlement & 2,114 & 74.433 & 13.642 & 50.000 & 65.385 & 77.778 & 83.333 & 90.909 \\
\hline \multirow[t]{2}{*}{ INSIDER OWNERSHIP } & First ann. & 1,477 & 4.420 & 8.225 & 0.541 & 1.077 & 1.659 & 3.574 & 18.701 \\
\hline & Settlement & 2,114 & 4.525 & 9.556 & 0.623 & 0.989 & 1.524 & 3.091 & 18.845 \\
\hline \multirow[t]{2}{*}{ BLOCK OWNERSHIP } & First ann. & 1,477 & 7.097 & 10.039 & 0.000 & 0.000 & 5.348 & 10.562 & 27.918 \\
\hline & Settlement & 2,114 & 7.678 & 9.998 & 0.000 & 0.000 & 5.569 & 11.472 & 26.962 \\
\hline \multirow[t]{2}{*}{ GINDEX } & First ann. & 1,435 & 9.180 & 2.584 & 5.000 & 8.000 & 9.000 & 11.000 & 13.000 \\
\hline & Settlement & 2,058 & 8.983 & 2.485 & 5.000 & 7.000 & 8.000 & 11.000 & 13.000 \\
\hline \multirow[t]{2}{*}{ RISK MANAGEMENT SCORE } & First ann. & 1,526 & 0.006 & 2.059 & -1.558 & -1.558 & -0.737 & 1.149 & 4.345 \\
\hline & Settlement & 2,184 & 0.003 & 2.093 & -1.902 & -1.902 & -0.847 & 1.646 & 3.550 \\
\hline \multicolumn{10}{|l|}{ Control Variables: } \\
\hline \multirow{2}{*}{ NUMBER OF ANALYSTS } & First ann. & 1,463 & 17.746 & 6.869 & 6.000 & 14.000 & 17.000 & 22.000 & 31.000 \\
\hline & Settlement & 2,142 & 16.533 & 6.634 & 3.000 & 13.000 & 17.000 & 20.000 & 27.000 \\
\hline \multirow[t]{2}{*}{ FIRM SIZE } & First ann. & 1,484 & 12.336 & 1.743 & 8.641 & 11.474 & 12.852 & 13.635 & 14.306 \\
\hline & Settlement & 2,156 & 12.351 & 1.968 & 7.697 & 11.516 & 13.054 & 13.728 & 14.417 \\
\hline \multirow[t]{2}{*}{ VOLATILITY } & First ann. & 1,484 & 2.226 & 1.048 & 0.981 & 1.514 & 2.080 & 2.673 & 3.748 \\
\hline & Settlement & 2,135 & 2.557 & 1.833 & 0.914 & 1.333 & 2.013 & 2.952 & 6.757 \\
\hline \multirow[t]{2}{*}{ LEVERAGE } & First ann. & 1,484 & 0.361 & 0.249 & 0.025 & 0.183 & 0.284 & 0.575 & 0.822 \\
\hline & Settlement & 2,156 & 0.326 & 0.240 & 0.020 & 0.138 & 0.266 & 0.558 & 0.783 \\
\hline \multirow[t]{2}{*}{ BETA } & First ann. & 1,484 & 1.306 & 0.427 & 0.715 & 0.971 & 1.322 & 1.604 & 2.090 \\
\hline & Settlement & 2,135 & 1.288 & 0.455 & 0.670 & 0.954 & 1.237 & 1.612 & 2.054 \\
\hline \multirow[t]{2}{*}{ PRICE } & First ann. & 1,372 & 59.185 & 39.348 & 3.674 & 38.231 & 54.143 & 75.586 & 128.382 \\
\hline & Settlement & 2,084 & 55.013 & 33.065 & 4.220 & 31.203 & 51.558 & 74.436 & 114.579 \\
\hline \multirow[t]{2}{*}{$\triangle \mathrm{PRICE}$} & First ann. & 1,372 & -0.148 & 10.668 & -16.313 & -4.170 & -0.105 & 4.050 & 16.015 \\
\hline & Settlement & 2,084 & 0.217 & 10.579 & -15.896 & -3.737 & 0.456 & 4.818 & 15.759 \\
\hline \multirow[t]{2}{*}{ VOLUME } & First ann. & 1,372 & 14.430 & 1.873 & 10.982 & 13.550 & 14.607 & 15.608 & 17.044 \\
\hline & Settlement & 2,084 & 14.558 & 1.822 & 11.093 & 13.586 & 14.789 & 15.666 & 17.417 \\
\hline \multirow[t]{2}{*}{$\triangle$ VOLUME } & First ann. & 1,372 & 0.041 & 0.654 & -0.901 & -0.320 & -0.014 & 0.346 & 1.195 \\
\hline & Settlement & 2,084 & -0.041 & 0.515 & -0.870 & -0.357 & -0.052 & 0.273 & 0.829 \\
\hline \multirow[t]{2}{*}{ QUOTED DEPTH } & First ann. & 1,372 & 3.513 & 0.961 & 2.124 & 2.895 & 3.393 & 3.982 & 5.209 \\
\hline & Settlement & 2,084 & 3.465 & 1.133 & 1.951 & 2.764 & 3.331 & 3.961 & 5.313 \\
\hline \multirow[t]{2}{*}{$\triangle$ QUOTED DEPTH } & First ann. & 1,372 & -0.008 & 0.389 & -0.590 & -0.253 & -0.037 & 0.203 & 0.679 \\
\hline & Settlement & 2,084 & -0.049 & 0.351 & -0.656 & -0.264 & -0.053 & 0.158 & 0.555 \\
\hline
\end{tabular}


Table 4: Descriptive Statistics: Information Asymmetry around Operational Risk Announcements

This table reports daily average abnormal effective spread and price impact of trade, along with abnormal changes in these variables, around operational risk announcements. Superscripts $* * *, * *$, and $*$ denote statistically significant difference of the average values from zero at the $1 \%, 5 \%$, and $10 \%$ levels, respectively.

Panel A: Information asymmetry by event period and event type

\begin{tabular}{|c|c|c|c|c|c|c|c|c|c|c|}
\hline \multirow{3}{*}{ Event Type } & \multirow{3}{*}{$\begin{array}{l}\text { Exp. } \\
\text { Sign }\end{array}$} & \multicolumn{4}{|c|}{ Effective Spread } & \multirow{3}{*}{$\begin{array}{l}\text { Exp. } \\
\text { Sign }\end{array}$} & \multicolumn{4}{|c|}{ Price Impact of Trade (30 min) } \\
\hline & & \multicolumn{2}{|c|}{$t=[-3,-1]$} & \multicolumn{2}{|c|}{$t=[0,+3]$} & & \multicolumn{2}{|c|}{$t=[-3,-1]$} & \multicolumn{2}{|c|}{$t=[0,+3]$} \\
\hline & & Mean & (t-stat) & Mean & (t-stat) & & Mean & (t-stat) & Mean & (t-stat) \\
\hline \multicolumn{11}{|l|}{ First announcements: } \\
\hline Internal Fraud & + & 0.8283 & $(4.98)^{* * *}$ & 1.4833 & $(5.72) * * *$ & + & 2.5403 & $(5.51)^{* * *}$ & 4.1108 & $(5.90)^{* * *}$ \\
\hline External Fraud & + & 0.5924 & $(4.92)^{* * *}$ & 0.6679 & $(6.03)^{* * *}$ & + & 2.0524 & $(6.99) * * *$ & 2.1521 & $(7.78)^{* * *}$ \\
\hline Clients, Products, \& Business Practices & + & 1.8380 & $(9.52)^{* * *}$ & 1.7841 & $(11.24)^{* * *}$ & + & 7.1696 & $(7.65)^{* * *}$ & 7.8625 & $(7.76)^{* * *}$ \\
\hline Other Events & + & 1.5185 & $(3.49)^{* * *}$ & 1.3952 & $(4.03)^{* * *}$ & + & 3.2754 & $(3.20) * * *$ & 2.8593 & $(4.95)^{* * *}$ \\
\hline All Events & + & 1.4707 & $(11.27)^{* * *}$ & 1.5369 & $(13.74)^{* * *}$ & + & 5.2420 & $(9.19)^{* * *}$ & 5.8479 & $(9.65)^{* * *}$ \\
\hline \multicolumn{11}{|l|}{ Settlement announcements: } \\
\hline Internal Fraud & + & 1.3673 & $(5.04)^{* * *}$ & 1.3464 & $(6.15)^{* * *}$ & + & 4.3405 & $(6.03)^{* * *}$ & 3.5141 & $(9.84)^{* * *}$ \\
\hline External Fraud & + & 0.6698 & $(2.45)^{* * *}$ & 0.4577 & $(4.87)^{* * *}$ & + & 1.7980 & $(4.45)^{* * *}$ & 1.7049 & $(9.64)^{* * *}$ \\
\hline Clients, Products, \& Business Practices & + & 1.3110 & $(11.00)^{* * *}$ & 1.3308 & $(12.46)^{* * *}$ & + & 3.5844 & $(12.89)^{* * *}$ & 3.3122 & $(15.00)^{* * *}$ \\
\hline Other Events & + & 1.0685 & $(5.00)^{* * *}$ & 1.0754 & $(5.12)^{* * *}$ & + & 2.9500 & $(6.35)^{* * *}$ & 2.2294 & $(7.52)^{* * *}$ \\
\hline All Events & + & 1.2453 & $(13.20)^{* * *}$ & 1.2420 & $(15.03)^{* * *}$ & + & 3.4825 & $(15.75)^{* * *}$ & 3.1007 & $(19.01)^{* * *}$ \\
\hline
\end{tabular}

Panel B: Change in information asymmetry by event period and event type

\begin{tabular}{|c|c|c|c|c|c|c|c|c|c|c|}
\hline \multirow{3}{*}{ Event Type } & \multirow{3}{*}{$\begin{array}{l}\text { Exp. } \\
\text { Sign }\end{array}$} & \multicolumn{4}{|c|}{ Change in Effective Spread } & \multicolumn{5}{|c|}{ Change in Price Impact of Trade (30 $\mathrm{min})$} \\
\hline & & \multicolumn{2}{|c|}{$t=[-3,-1]$} & \multicolumn{2}{|c|}{$t=[0,+3]$} & \multirow{2}{*}{$\begin{array}{l}\text { Exp. } \\
\text { Sign }\end{array}$} & \multicolumn{2}{|c|}{$t=[-3,-1]$} & \multicolumn{2}{|c|}{$t=[0,+3]$} \\
\hline & & Mean & (t-stat) & Mean & (t-stat) & & Mean & (t-stat) & Mean & (t-stat) \\
\hline \multicolumn{11}{|l|}{ First announcements: } \\
\hline Internal Fraud & + & -0.1163 & $(-1.13)$ & 0.5281 & $(2.12)^{* * *}$ & + & 0.1260 & $(0.41)$ & 1.6970 & $(2.73)^{* * *}$ \\
\hline External Fraud & + & 0.0843 & $(0.95)$ & 0.1598 & $(1.99)^{* * *}$ & + & 0.4366 & $(2.07)^{* * *}$ & 0.5363 & $(2.65)^{* * *}$ \\
\hline Clients, Products, \& Business Practices & + & 0.1148 & $(0.80)$ & 0.0047 & $(0.04)$ & + & 0.9081 & $(1.55)^{*}$ & 0.8502 & $(1.53)^{*}$ \\
\hline Other Events & + & -0.4303 & $(-1.57)$ & -0.4999 & $(-1.99)^{* *}$ & + & -1.1993 & $(-1.61)$ & -1.6155 & $(-2.75)^{* * *}$ \\
\hline All Events & + & 0.0019 & $(0.02)$ & 0.0412 & $(0.48)$ & + & 0.4423 & $(1.24)$ & 0.6154 & $(1.78)^{* *}$ \\
\hline \multicolumn{11}{|l|}{ Settlement announcements: } \\
\hline Internal Fraud & - & 0.0877 & $(0.43)$ & 0.0439 & $(0.28)$ & - & -2.7021 & $(-2.18)^{* * *}$ & -3.9323 & $(-3.27)^{* * *}$ \\
\hline External Fraud & - & -0.0004 & $(-0.00)$ & -0.1489 & $(-1.57)^{*}$ & - & -0.0589 & $(-0.16)$ & -0.1520 & $(-0.69)$ \\
\hline Clients, Products, \& Business Practices & - & -0.0014 & $(-0.02)$ & 0.0329 & $(0.46)$ & - & -0.1682 & $(-0.48)$ & -0.0562 & $(-0.24)$ \\
\hline Other Events & - & -0.1789 & $(-0.94)$ & -0.1744 & $(-1.00)$ & - & -2.3886 & $(-1.71)^{* *}$ & -2.9722 & $(-2.50)^{* * *}$ \\
\hline All Events & - & -0.0102 & $(-0.15)$ & -0.0023 & $(-0.04)$ & - & -0.7369 & $(-2.22)^{* * *}$ & -0.8913 & $(-3.38)^{* * *}$ \\
\hline
\end{tabular}


Panel C: Mean comparison of information asymmetry by sub-samples of explanatory variables

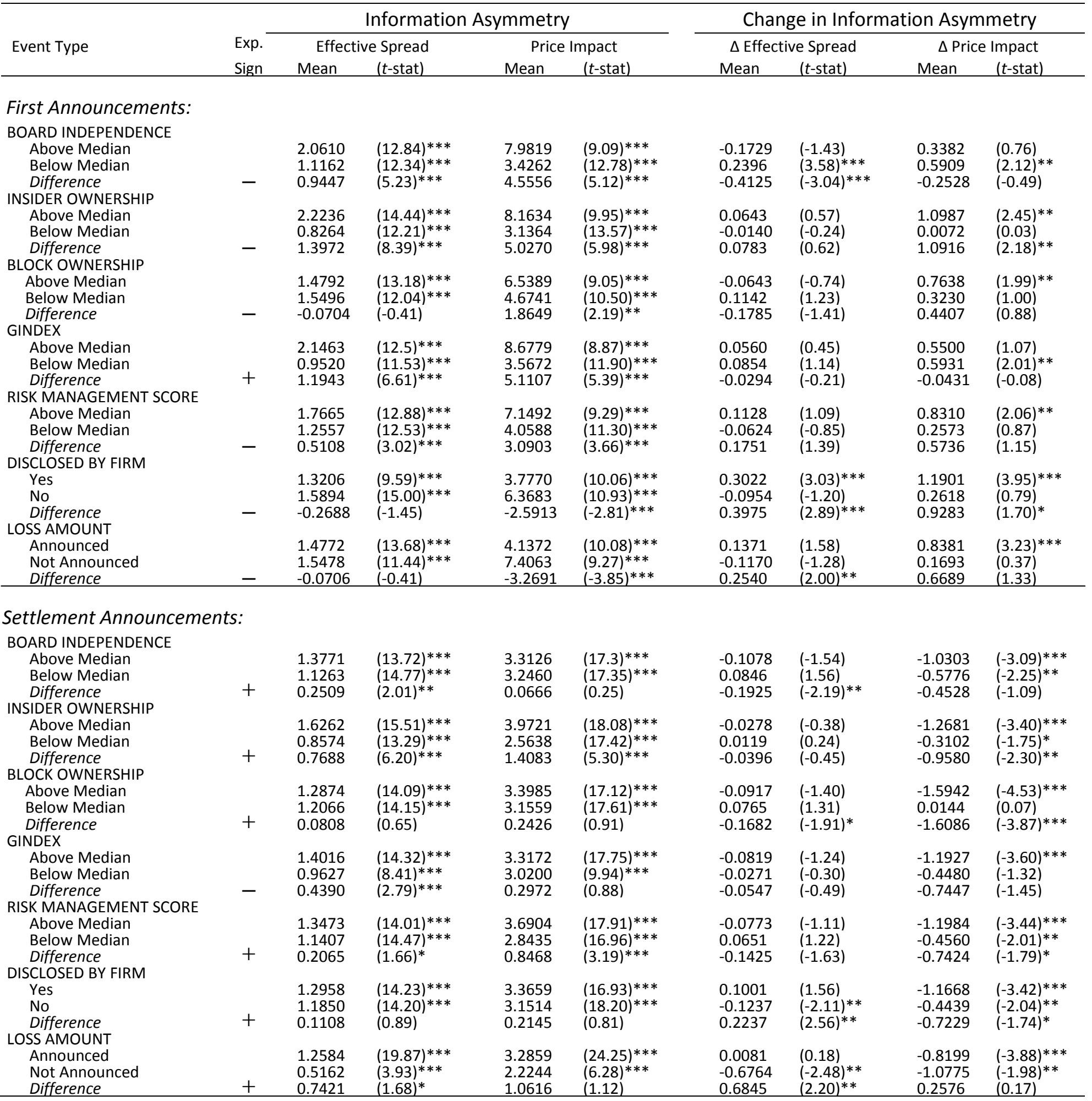


Table 5: Multivariate Results: Determinants of Information Asymmetry

This table presents the results of our OLS model. The dependent variable is a daily measure of information asymmetry during $t=[-3,+3] . t$-statistics based on heteroscedasticity-robust standard errors are reported in parentheses. Superscripts $* * *, * *$, and ${ }^{*}$ denote statistical significance at the $1 \%, 5 \%$, and $10 \%$ levels, respectively.

\begin{tabular}{|c|c|c|c|c|c|c|c|c|c|c|}
\hline \multirow{3}{*}{ Variable } & \multirow[b]{3}{*}{$\begin{array}{l}\text { Exp. } \\
\text { Sign }\end{array}$} & \multicolumn{4}{|c|}{ First Announcements } & \multicolumn{5}{|c|}{ Settlement Announcements } \\
\hline & & \multicolumn{2}{|c|}{ Effective Spread } & \multicolumn{2}{|c|}{ Price Impact (30 min) } & \multirow[b]{2}{*}{$\begin{array}{l}\text { Exp. } \\
\text { Sign }\end{array}$} & \multicolumn{2}{|c|}{ Effective Spread } & \multicolumn{2}{|c|}{ Price Impact (30 min) } \\
\hline & & $\begin{array}{c}\text { (1) } \\
\text { level }\end{array}$ & $\begin{array}{c}(2) \\
\text { Change }(\Lambda)\end{array}$ & $\begin{array}{c}\text { (3) } \\
\text { level }\end{array}$ & $\frac{(4)}{\text { Change }(\Lambda)}$ & & $\begin{array}{c}\text { (5) } \\
\text { level }\end{array}$ & (6) & (7) & $\begin{array}{c}\text { (8) } \\
\text { (8) }\end{array}$ \\
\hline \multicolumn{11}{|l|}{ Governance and Risk Management: } \\
\hline BOARD INDEPENDENCE & - & $\begin{array}{c}-0.0212 \\
(-2.96)^{* * *}\end{array}$ & $\begin{array}{c}-0.0229 \\
(-3.57)^{* * *}\end{array}$ & $\begin{array}{c}-0.0092 \\
(-0.27)\end{array}$ & $\begin{array}{c}-0.0294 \\
(-1.15)\end{array}$ & + & $\begin{array}{c}0.0026 \\
(0.47)\end{array}$ & $\begin{array}{c}0.0048 \\
(1.04)\end{array}$ & $\begin{array}{l}-0.0237 \\
(-1.83)^{*}\end{array}$ & $\begin{array}{c}0.0079 \\
(0.51)\end{array}$ \\
\hline INSIDER OWNERSHIP & - & $\begin{array}{c}-0.0480 \\
(-4.14)^{* * *}\end{array}$ & $\begin{array}{c}-0.0232 \\
(-2.66)^{* * *}\end{array}$ & $\begin{array}{c}-0.1652 \\
(-3.61)^{* * *}\end{array}$ & $\begin{array}{l}-0.0661 \\
(-1.88)^{*}\end{array}$ & + & $\begin{array}{c}0.0482 \\
(2.71)^{* * *}\end{array}$ & $\begin{array}{c}0.0327 \\
(2.67)^{* * *}\end{array}$ & $\begin{array}{c}0.0975 \\
(2.47)^{* *}\end{array}$ & $\begin{array}{c}0.0752 \\
(2.00)^{* *}\end{array}$ \\
\hline BLOCK OWNERSHIP & - & $\begin{array}{c}-0.0105 \\
(-1.13)\end{array}$ & $\begin{array}{c}-0.0237 \\
(-3.01)^{* * *}\end{array}$ & $\begin{array}{c}-0.0938 \\
(-2.49)^{* *}\end{array}$ & $\begin{array}{c}-0.0363 \\
(-1.58)\end{array}$ & + & $\begin{array}{c}0.0085 \\
(1.17)\end{array}$ & $\begin{array}{c}0.0151 \\
(2.93)^{* * *}\end{array}$ & $\begin{array}{c}0.0213 \\
(1.43)\end{array}$ & $\begin{array}{c}0.0838 \\
(2.88)^{* * *}\end{array}$ \\
\hline GINDEX & + & $\begin{array}{c}0.1362 \\
(3.85)^{* * *}\end{array}$ & $\begin{array}{c}0.0410 \\
(1.60)\end{array}$ & $\begin{array}{c}0.4625 \\
(3.14)^{* * *}\end{array}$ & $\begin{array}{c}-0.0792 \\
(-0.69)\end{array}$ & - & $\begin{array}{l}-0.0490 \\
(-1.86)^{*}\end{array}$ & $\begin{array}{c}-0.0053 \\
(-0.24)\end{array}$ & $\begin{array}{c}-0.0707 \\
(-1.24)\end{array}$ & $\begin{array}{c}0.2528 \\
(2.79)^{* * *}\end{array}$ \\
\hline RISK MANAGEMENT SCORE & - & $\begin{array}{c}0.0359 \\
(0.93)\end{array}$ & $\begin{array}{l}0.0577 \\
(1.44)\end{array}$ & $\begin{array}{c}0.4109 \\
(1.45)\end{array}$ & $\begin{array}{l}0.3000 \\
(1.72)^{*}\end{array}$ & + & $\begin{array}{l}-0.0923 \\
(-2.30)^{* *}\end{array}$ & $\begin{array}{c}-0.0373 \\
(-1.08)\end{array}$ & $\begin{array}{l}-0.1445 \\
(-1.65)^{*}\end{array}$ & $\begin{array}{c}0.3956 \\
(3.19)^{* * *}\end{array}$ \\
\hline Announcement Characteristics: & & & & & & & & & & \\
\hline INTERNAL FRAUD & + & $\begin{array}{l}-0.5053 \\
(-1.70)^{*}\end{array}$ & $\begin{array}{c}0.3351 \\
(1.43)\end{array}$ & $\begin{array}{c}0.9637 \\
(1.07)\end{array}$ & $\begin{array}{c}1.8281 \\
(2.57)^{* * *}\end{array}$ & + & $\begin{array}{c}0.3111 \\
(1.44)\end{array}$ & $\begin{array}{l}0.3687 \\
(1.82)^{*}\end{array}$ & $\begin{array}{l}0.8146 \\
(1.72)^{*}\end{array}$ & $\begin{array}{c}-0.5769 \\
(-0.46)\end{array}$ \\
\hline EXTERNAL FRAUD & + & $\begin{array}{c}-0.7477 \\
(-2.70)^{* * *}\end{array}$ & $\begin{array}{l}0.2911 \\
(1.42)\end{array}$ & $\begin{array}{l}-2.5348 \\
(-2.21)^{* *}\end{array}$ & $\begin{array}{c}-0.0502 \\
(-0.08)\end{array}$ & - & $\begin{array}{c}-0.2993 \\
(-1.28)\end{array}$ & $\begin{array}{l}0.1327 \\
(0.72)\end{array}$ & $\begin{array}{c}-0.9377 \\
(-2.23)^{* *}\end{array}$ & $\begin{array}{c}1.6934 \\
(1.96)^{* *}\end{array}$ \\
\hline CLIENTS, PRODUCTS, \& BUS. PRACTICES & + & $\begin{array}{c}-0.1719 \\
(-0.61)\end{array}$ & $\begin{array}{c}0.2027 \\
(0.89)\end{array}$ & $\begin{array}{c}2.5910 \\
(2.74)^{* * *}\end{array}$ & $\begin{array}{l}1.3605 \\
(1.82)^{*}\end{array}$ & + & $\begin{array}{c}0.2564 \\
(1.46)\end{array}$ & $\begin{array}{l}0.2766 \\
(1.83)^{*}\end{array}$ & $\begin{array}{c}0.5279 \\
(1.54)\end{array}$ & $\begin{array}{c}2.7015 \\
(2.95)^{* * *}\end{array}$ \\
\hline DISCLOSED BY FIRM & - & $\begin{array}{c}0.2913 \\
(1.44)\end{array}$ & $\begin{array}{l}0.0757 \\
(0.48)\end{array}$ & $\begin{array}{c}-0.6579 \\
(-1.02)\end{array}$ & $\begin{array}{c}-0.4756 \\
(-1.03)\end{array}$ & + & $\begin{array}{c}0.2665 \\
(2.18)^{* *}\end{array}$ & $\begin{array}{c}0.2225 \\
(2.38)^{* *}\end{array}$ & $\begin{array}{c}0.6760 \\
(2.46)^{* *}\end{array}$ & $\begin{array}{c}-0.8801 \\
(-2.02)^{* *}\end{array}$ \\
\hline LOSS ANNOUNCED & - & $\begin{array}{c}0.1578 \\
(0.91)\end{array}$ & $\begin{array}{c}0.3295 \\
(2.20)^{* *}\end{array}$ & $\begin{array}{c}-3.0073 \\
(-2.99)^{* * *}\end{array}$ & $\begin{array}{c}1.2339 \\
(2.06)^{* *}\end{array}$ & + & $\begin{array}{c}0.9102 \\
(5.47)^{* * *}\end{array}$ & $\begin{array}{c}0.7858 \\
(2.66)^{* * *}\end{array}$ & $\begin{array}{c}2.0749 \\
(4.06)^{* * *}\end{array}$ & $\begin{array}{c}-0.4558 \\
(-0.61)\end{array}$ \\
\hline NUMBER OF ANALYSTS & & $\begin{array}{c}0.0714 \\
(5.08)^{* * *}\end{array}$ & $\begin{array}{c}0.0106 \\
(0.92)\end{array}$ & $\begin{array}{c}0.6051 \\
(4.41)^{* * *}\end{array}$ & $\begin{array}{l}0.1393 \\
(1.94)^{*}\end{array}$ & & $\begin{array}{c}0.1070 \\
(8.59)^{* * *}\end{array}$ & $\begin{array}{c}-0.0035 \\
(-0.38)\end{array}$ & $\begin{array}{c}0.1921 \\
(6.36)^{* * *}\end{array}$ & $\begin{array}{c}-0.0895 \\
(-2.02)^{* *}\end{array}$ \\
\hline FIRM SIZE & & $\begin{array}{c}0.4091 \\
(4.35)^{* * *}\end{array}$ & $\begin{array}{c}-0.1540 \\
(-3.18)^{* * *}\end{array}$ & $\begin{array}{l}-1.3330 \\
(-1.86)^{*}\end{array}$ & $\begin{array}{c}-1.5782 \\
(-4.32)^{* * *}\end{array}$ & & $\begin{array}{c}0.4537 \\
(7.35)^{* * *}\end{array}$ & $\begin{array}{c}0.0921 \\
(2.40)^{* *}\end{array}$ & $\begin{array}{c}0.5034 \\
(3.19)^{* * *}\end{array}$ & $\begin{array}{c}0.5356 \\
(2.24)^{* *}\end{array}$ \\
\hline VOLATILITY & & $\begin{array}{c}0.3797 \\
(3.57)^{* * *}\end{array}$ & $\begin{array}{c}-0.0729 \\
(-0.97)\end{array}$ & $\begin{array}{c}1.0666 \\
(2.54)^{* *}\end{array}$ & $\begin{array}{c}-0.3659 \\
(-1.37)\end{array}$ & & $\begin{array}{c}-0.0336 \\
(-0.75)\end{array}$ & $\begin{array}{c}-0.0492 \\
(-1.61)\end{array}$ & $\begin{array}{c}-0.2813 \\
(-2.61)^{* * *}\end{array}$ & $\begin{array}{c}-0.2236 \\
(-1.60)\end{array}$ \\
\hline LEVERAGE & & $\begin{array}{l}0.8562 \\
(1.67)^{*}\end{array}$ & $\begin{array}{c}0.0398 \\
(0.10)\end{array}$ & $\begin{array}{c}0.8577 \\
(0.35)\end{array}$ & $\begin{array}{c}-0.7955 \\
(-0.40)\end{array}$ & & $\begin{array}{c}0.5099 \\
(1.11)\end{array}$ & $\begin{array}{c}-0.9622 \\
(-2.78)^{* * *}\end{array}$ & $\begin{array}{l}1.6110 \\
(1.59)\end{array}$ & $\begin{array}{c}-5.0631 \\
(-3.71)^{* * *}\end{array}$ \\
\hline BETA & & $\begin{array}{c}-0.3571 \\
(-1.18)\end{array}$ & $\begin{array}{c}0.1463 \\
(0.58)\end{array}$ & $\begin{array}{c}6.4675 \\
(3.56)^{* * *}\end{array}$ & $\begin{array}{c}3.3125 \\
(3.14)^{* * *}\end{array}$ & & $\begin{array}{c}-0.0765 \\
(-0.40)\end{array}$ & $\begin{array}{c}0.1129 \\
(0.82)\end{array}$ & $\begin{array}{c}1.4999 \\
(2.85)^{* * *}\end{array}$ & $\begin{array}{c}0.0318 \\
(0.05)\end{array}$ \\
\hline$(\Delta)$ PRICE & & $\begin{array}{c}-0.0184 \\
(-6.74)^{* * *}\end{array}$ & $\begin{array}{c}-0.0226 \\
(-2.37)^{* *}\end{array}$ & $\begin{array}{c}-0.0427 \\
(-3.68)^{* * *}\end{array}$ & $\begin{array}{c}-0.0078 \\
(-0.16)\end{array}$ & & $\begin{array}{c}-0.0188 \\
(-7.45)^{* * *}\end{array}$ & $\begin{array}{c}-0.0108 \\
(-2.19)^{* *}\end{array}$ & $\begin{array}{c}-0.0294 \\
(-5.42)^{* * *}\end{array}$ & $\begin{array}{c}-0.0363 \\
(-1.29)\end{array}$ \\
\hline$(\Delta)$ VOLUME & & $\begin{array}{c}-0.8837 \\
(-9.13)^{* * *}\end{array}$ & $\begin{array}{r}0.0507 \\
(0.28)\end{array}$ & $\begin{array}{c}-2.0200 \\
(-3.66)^{* * *}\end{array}$ & $\begin{array}{c}1.8413 \\
(2.59)^{* * *}\end{array}$ & & $\begin{array}{c}-0.7789 \\
(-11.22)^{* * *}\end{array}$ & $\begin{array}{c}0.3301 \\
(3.44)^{* * *}\end{array}$ & $\begin{array}{c}-0.8284 \\
(-5.62)^{* * *}\end{array}$ & $\begin{array}{c}0.3573 \\
(0.62)\end{array}$ \\
\hline DECIMAL & & $\begin{array}{c}1.6659 \\
(5.92)^{* * *}\end{array}$ & $\begin{array}{c}0.4650 \\
(2.18)^{* *}\end{array}$ & $\begin{array}{c}8.5909 \\
(6.10)^{* * *}\end{array}$ & $\begin{array}{c}2.5379 \\
(3.23)^{* * *}\end{array}$ & & $\begin{array}{c}1.6818 \\
(9.51)^{* * *}\end{array}$ & $\begin{array}{c}-0.0783 \\
(-0.77)\end{array}$ & $\begin{array}{c}3.7375 \\
(10.16)^{* * *}\end{array}$ & $\begin{array}{c}-2.8351 \\
(-4.41)^{* * *}\end{array}$ \\
\hline BANKS & & $\begin{array}{c}-0.2017 \\
(-1.35)\end{array}$ & $\begin{array}{c}0.5011 \\
(3.54)^{* * *}\end{array}$ & $\begin{array}{c}-1.3663 \\
(-1.54)\end{array}$ & $\begin{array}{c}0.5328 \\
(0.76)\end{array}$ & & $\begin{array}{c}-0.6695 \\
(-3.93)^{* * *}\end{array}$ & $\begin{array}{c}0.1414 \\
(1.04)\end{array}$ & $\begin{array}{c}-0.1574 \\
(-0.36)\end{array}$ & $\begin{array}{c}1.9993 \\
(3.21)^{* * *}\end{array}$ \\
\hline INSURERS & & $\begin{array}{l}0.5915 \\
(1.51)\end{array}$ & $\begin{array}{c}1.1629 \\
(4.06)^{* * *}\end{array}$ & $\begin{array}{c}-0.9986 \\
(-0.72)\end{array}$ & $\begin{array}{l}1.5359 \\
(1.38)\end{array}$ & & $\begin{array}{c}-0.9211 \\
(-4.05)^{* * *}\end{array}$ & $\begin{array}{c}-0.2146 \\
(-1.24)\end{array}$ & $\begin{array}{c}-0.0890 \\
(-0.15)\end{array}$ & $\begin{array}{c}1.1482 \\
(2.03)^{* *}\end{array}$ \\
\hline Constant & & $\begin{array}{c}7.7821 \\
(7.67)^{* * *}\end{array}$ & $\begin{array}{c}2.0790 \\
(2.81)^{* * *}\end{array}$ & $\begin{array}{c}24.6393 \\
(4.07)^{* * *}\end{array}$ & $\begin{array}{c}13.7076 \\
(3.83)^{* * *}\end{array}$ & & $\begin{array}{c}4.1159 \\
(5.00)^{* * *}\end{array}$ & $\begin{array}{c}-2.4087 \\
(-4.14)^{* * *}\end{array}$ & $\begin{array}{l}1.9414 \\
(1.03) \\
\end{array}$ & $\begin{array}{c}-7.2450 \\
(-2.35)^{* *}\end{array}$ \\
\hline Number of & & 1,316 & 1,316 & 1,316 & 1,316 & & 2,014 & 2,014 & 2,014 & 2,014 \\
\hline F-stat. all variables & & 12.04 & 3.43 & 5.48 & 3.34 & & 16.89 & 3.29 & 12.59 & 2.99 \\
\hline$[$ Prob $>F]$ & & {$[0.000]^{* * *}$} & {$[0.000]^{* * *}$} & {$[0.000]^{* * *}$} & {$[0.000]^{* * *}$} & & {$[0.000]^{* * *}$} & {$[0.000]^{* * *}$} & {$[0.000]^{* * *}$} & {$[0.000]^{* * *}$} \\
\hline $\begin{array}{l}\text { F-stat. governance \& risk management } \\
{[\text { Prob }>F]}\end{array}$ & & $\begin{array}{c}5.91 \\
{[0.000]^{* * *}}\end{array}$ & $\begin{array}{c}3.98 \\
{[0.001]^{* * *}}\end{array}$ & $\begin{array}{c}4.50 \\
{[0.001]^{* * *}}\end{array}$ & $\begin{array}{c}3.65 \\
{[0.003]^{* * *}}\end{array}$ & & $\begin{array}{c}4.41 \\
{[0.001]^{* * *}}\end{array}$ & $\begin{array}{c}4.36 \\
{[0.001]^{* * *}}\end{array}$ & $\begin{array}{c}7.11 \\
{[0.000]^{* * *}}\end{array}$ & $\begin{array}{c}4.05 \\
{[0.001]^{* * *}}\end{array}$ \\
\hline $\begin{array}{l}\text { F-stat. announcement characteristics } \\
{[\text { Prob }>F]}\end{array}$ & & $\begin{array}{c}2.39 \\
{[0.036]^{* *}}\end{array}$ & $\begin{array}{c}2.09 \\
{[0.064]^{*}}\end{array}$ & $\begin{array}{c}5.01 \\
{[0.000]^{* * *}}\end{array}$ & $\begin{array}{c}3.13 \\
{[0.008]^{* * *}}\end{array}$ & & $\begin{array}{c}9.29 \\
{[0.000]^{* * *}}\end{array}$ & $\begin{array}{c}3.55 \\
{[0.003]^{* * *}}\end{array}$ & $\begin{array}{c}8.46 \\
{[0.000]^{* * *}}\end{array}$ & $\begin{array}{c}3.55 \\
{[0.003]^{* * *}}\end{array}$ \\
\hline$R^{2}$ & & 0.3045 & 0.0779 & 0.1536 & 0.0821 & & 0.2841 & 0.0393 & 0.1429 & 0.0505 \\
\hline$A I C$ & & $6,360.21$ & $5,959.40$ & $10,854.48$ & $9,573.49$ & & $9,343.60$ & $8,527.50$ & $12,769.94$ & $14,766.67$ \\
\hline$B I C$ & & $6,469.04$ & $6,068.23$ & $10,963.31$ & $9,682.32$ & & $9,461.36$ & $8,645.27$ & $12,887.70$ & $14,884.44$ \\
\hline
\end{tabular}


Table 6: Multivariate Results: Information Asymmetry During Pre- and Post-Announcement Periods

The dependent variable is a daily measure of information asymmetry during pre-announcement period $t=[-3,-1]$ and during post-announcement period $t=[0,+3]$. $t$-statistics based on heteroscedasticity-robust standard errors are reported in parentheses. Superscripts $* * *, * *$, and $*$ denote statistical significance at the $1 \%, 5 \%$, and $10 \%$ levels, respectively.

Panel A: First announcements

\begin{tabular}{|c|c|c|c|c|c|c|c|c|c|c|}
\hline \multirow{3}{*}{ Variable } & \multirow[b]{3}{*}{$\begin{array}{l}\text { Exp. } \\
\text { Sign }\end{array}$} & \multicolumn{4}{|c|}{ Effective Spread } & \multicolumn{5}{|c|}{ Price Impact of Trade (30 $\mathrm{min})$} \\
\hline & & \multicolumn{2}{|c|}{ Level } & \multicolumn{2}{|c|}{ Change $(\Delta)$} & \multirow[b]{2}{*}{$\begin{array}{l}\text { Exp. } \\
\text { Sign }\end{array}$} & \multicolumn{2}{|c|}{ Level } & \multicolumn{2}{|c|}{ Change $(\Delta)$} \\
\hline & & $\begin{array}{c}(1) \\
t=[-3,-1]\end{array}$ & $\begin{array}{c}(2) \\
t=[0,+3]\end{array}$ & $\begin{array}{c}(3) \\
t=[-3,-1]\end{array}$ & $\begin{array}{c}(4) \\
t=[0,+3]\end{array}$ & & $\begin{array}{c}5) \\
t=[-3,-1]\end{array}$ & $\begin{array}{c}(6) \\
t=[0,+3]\end{array}$ & $\begin{array}{c}(7) \\
t=[-3,-1]\end{array}$ & $\begin{array}{c}(8) \\
t=[0,+3]\end{array}$ \\
\hline Governance and Risk Management: & & & & & & & & & & \\
\hline BOARD INDEPENDENCE & - & $\begin{array}{c}-0.0123 \\
(-1.24)\end{array}$ & $\begin{array}{c}-0.0282 \\
(-3.03)^{* * *}\end{array}$ & $\begin{array}{c}-0.0110 \\
(-1.20)\end{array}$ & $\begin{array}{c}-0.0316 \\
(-3.83)^{* * *}\end{array}$ & - & $\begin{array}{c}0.0178 \\
(0.44)\end{array}$ & $\begin{array}{c}-0.0316 \\
(-0.63)\end{array}$ & $\begin{array}{c}0.0059 \\
(0.16)\end{array}$ & $\begin{array}{c}-0.0532 \\
(-1.58)\end{array}$ \\
\hline INSIDER OWNERSHIP & - & $\begin{array}{c}-0.0180 \\
(-1.29)\end{array}$ & $\begin{array}{c}-0.0698 \\
(-4.47)^{* * *}\end{array}$ & $\begin{array}{c}-0.0018 \\
(-0.17)\end{array}$ & $\begin{array}{c}-0.0397 \\
(-3.28)^{* * *}\end{array}$ & - & $\begin{array}{c}-0.0534 \\
(-0.89)\end{array}$ & $\begin{array}{c}-0.2520 \\
(-3.81)^{* * *}\end{array}$ & $\begin{array}{c}0.0066 \\
(0.12)\end{array}$ & $\begin{array}{c}-0.1197 \\
(-2.66)^{* * *}\end{array}$ \\
\hline BLOCK OWNERSHIP & - & $\begin{array}{c}-0.0006 \\
(-0.05)\end{array}$ & $\begin{array}{c}-0.0180 \\
(-1.43)\end{array}$ & $\begin{array}{c}-0.0134 \\
(-1.21)\end{array}$ & $\begin{array}{c}-0.0305 \\
(-2.91)^{* * *}\end{array}$ & - & $\begin{array}{c}-0.0202 \\
(-0.49)\end{array}$ & $\begin{array}{c}-0.1496 \\
(-2.56)^{* *}\end{array}$ & $\begin{array}{c}0.0134 \\
(0.46)\end{array}$ & $\begin{array}{c}-0.0705 \\
(-2.07)^{* *}\end{array}$ \\
\hline GINDEX & + & $\begin{array}{c}0.1533 \\
(2.83)^{* * *}\end{array}$ & $\begin{array}{c}0.1256 \\
(2.72)^{* * *}\end{array}$ & $\begin{array}{c}0.0512 \\
(1.46)\end{array}$ & $\begin{array}{c}0.0323 \\
(0.91)\end{array}$ & + & $\begin{array}{c}0.1733 \\
(0.77)\end{array}$ & $\begin{array}{c}0.6832 \\
(3.57)^{* * *}\end{array}$ & $\begin{array}{l}-0.3479 \\
(-1.92)^{*}\end{array}$ & $\begin{array}{c}0.1103 \\
(0.78)\end{array}$ \\
\hline RISK MANAGEMENT SCORE & - & $\begin{array}{c}0.0686 \\
(1.12)\end{array}$ & $\begin{array}{c}0.0199 \\
(0.39)\end{array}$ & $\begin{array}{c}0.0362 \\
(0.62)\end{array}$ & $\begin{array}{c}0.0674 \\
(1.21)\end{array}$ & - & $\begin{array}{c}0.1664 \\
(0.47)\end{array}$ & $\begin{array}{r}0.6147 \\
(1.44)\end{array}$ & $\begin{array}{c}0.0507 \\
(0.21)\end{array}$ & $\begin{array}{l}0.4640 \\
(1.86)^{*}\end{array}$ \\
\hline Announcement Characteristics: & & & & & & & & & & \\
\hline INTERNAL FRAUD & + & $\begin{array}{c}-0.6098 \\
(-1.43)\end{array}$ & $\begin{array}{c}-0.3851 \\
(-0.94)\end{array}$ & $\begin{array}{c}0.1721 \\
(0.57)\end{array}$ & $\begin{array}{c}0.4793 \\
(1.43)\end{array}$ & + & $\begin{array}{c}0.6565 \\
(0.50)\end{array}$ & $\begin{array}{c}1.2487 \\
(1.00)\end{array}$ & $\begin{array}{l}1.7713 \\
(1.72)^{*}\end{array}$ & $\begin{array}{c}1.9019 \\
(1.98)^{* *}\end{array}$ \\
\hline EXTERNAL FRAUD & + & $\begin{array}{c}-0.4761 \\
(-1.14)\end{array}$ & $\begin{array}{c}-0.8917 \\
(-2.38)^{* *}\end{array}$ & $\begin{array}{c}0.3146 \\
(1.08)\end{array}$ & $\begin{array}{c}0.3076 \\
(1.05)\end{array}$ & + & $\begin{array}{c}-1.6511 \\
(-1.07)\end{array}$ & $\begin{array}{l}-3.1618 \\
(-1.92)^{*}\end{array}$ & $\begin{array}{c}0.3483 \\
(0.37)\end{array}$ & $\begin{array}{c}-0.2519 \\
(-0.26)\end{array}$ \\
\hline CLIENTS, PRODUCTS, \& BUS. PRACTICES & + & $\begin{array}{c}0.1227 \\
(0.28)\end{array}$ & $\begin{array}{c}-0.3468 \\
(-0.93)\end{array}$ & $\begin{array}{c}0.4224 \\
(1.21)\end{array}$ & $\begin{array}{c}0.0683 \\
(0.22)\end{array}$ & + & $\begin{array}{l}2.3727 \\
(1.77)^{*}\end{array}$ & $\begin{array}{c}2.7727 \\
(2.18)^{* *}\end{array}$ & $\begin{array}{l}1.5041 \\
(1.33)\end{array}$ & $\begin{array}{c}1.3209 \\
(1.34)\end{array}$ \\
\hline DISCLOSED BY FIRM & - & $\begin{array}{c}0.3896 \\
(1.45)\end{array}$ & $\begin{array}{c}0.2046 \\
(0.73)\end{array}$ & $\begin{array}{l}0.3654 \\
(1.95)^{*}\end{array}$ & $\begin{array}{c}-0.1354 \\
(-0.60)\end{array}$ & - & $\begin{array}{c}0.3989 \\
(0.45)\end{array}$ & $\begin{array}{c}-1.4522 \\
(-1.63)\end{array}$ & $\begin{array}{c}0.5659 \\
(0.91)\end{array}$ & $\begin{array}{c}-1.2739 \\
(-2.00)^{* *}\end{array}$ \\
\hline LOSS ANNOUNCED & - & $\begin{array}{c}-0.1896 \\
(-0.74)\end{array}$ & $\begin{array}{l}0.4244 \\
(1.81)^{*}\end{array}$ & $\begin{array}{c}-0.0533 \\
(-0.24)\end{array}$ & $\begin{array}{c}0.6463 \\
(3.27)^{* * *}\end{array}$ & 一 & $\begin{array}{c}-4.6756 \\
(-3.55)^{* * *}\end{array}$ & $\begin{array}{c}-1.7677 \\
(-1.22)\end{array}$ & $\begin{array}{c}-0.4184 \\
(-0.53)\end{array}$ & $\begin{array}{c}2.5406 \\
(2.94)^{* * *}\end{array}$ \\
\hline Control Variables: & & & & & & & & & & \\
\hline NUMBER OF ANALYSTS & & $\begin{array}{c}0.0566 \\
(2.63)^{* * *}\end{array}$ & $\begin{array}{c}0.0818 \\
(4.36)^{* * *}\end{array}$ & $\begin{array}{c}-0.0032 \\
(-0.18)\end{array}$ & $\begin{array}{c}0.0194 \\
(1.27)\end{array}$ & & $\begin{array}{c}0.4066 \\
(2.15)^{* *}\end{array}$ & $\begin{array}{c}0.7557 \\
(3.88)^{* * *}\end{array}$ & $\begin{array}{c}0.0536 \\
(0.49)\end{array}$ & $\begin{array}{c}0.2012 \\
(2.16)^{* *}\end{array}$ \\
\hline FIRM SIZE & & $\begin{array}{c}0.5902 \\
(4.61)^{* * *}\end{array}$ & $\begin{array}{c}0.2896 \\
(2.31)^{* *}\end{array}$ & $\begin{array}{c}-0.0219 \\
(-0.35)\end{array}$ & $\begin{array}{c}-0.2380 \\
(-3.51)^{* * *}\end{array}$ & & $\begin{array}{c}-0.5066 \\
(-0.56)\end{array}$ & $\begin{array}{l}-1.9357 \\
(-1.86)^{*}\end{array}$ & $\begin{array}{c}-1.1491 \\
(-2.38)^{* *}\end{array}$ & $\begin{array}{c}-1.8599 \\
(-3.56)^{* * *}\end{array}$ \\
\hline VOLATILITY & & $\begin{array}{c}0.5613 \\
(3.57)^{* * *}\end{array}$ & $\begin{array}{l}0.2610 \\
(1.87)^{*}\end{array}$ & $\begin{array}{c}0.0617 \\
(0.52)\end{array}$ & $\begin{array}{l}-0.1755 \\
(-1.84)^{*}\end{array}$ & & $\begin{array}{c}1.2803 \\
(2.59)^{* * *}\end{array}$ & $\begin{array}{c}0.9340 \\
(1.51)\end{array}$ & $\begin{array}{c}-0.2925 \\
(-0.70)\end{array}$ & $\begin{array}{c}-0.4197 \\
(-1.18)\end{array}$ \\
\hline LEVERAGE & & $\begin{array}{c}-0.5239 \\
(-0.74)\end{array}$ & $\begin{array}{c}1.8058 \\
(2.62)^{* * *}\end{array}$ & $\begin{array}{c}-1.1535 \\
(-2.16)^{* *}\end{array}$ & $\begin{array}{c}0.8122 \\
(1.44)\end{array}$ & & $\begin{array}{c}-5.5222 \\
(-1.23)\end{array}$ & $\begin{array}{c}5.5646 \\
(2.32)^{* *}\end{array}$ & $\begin{array}{c}-5.0087 \\
(-1.36)\end{array}$ & $\begin{array}{c}2.1931 \\
(1.16)\end{array}$ \\
\hline BETA & & $\begin{array}{l}-0.9088 \\
(-1.80)^{*}\end{array}$ & $\begin{array}{c}0.0526 \\
(0.14)\end{array}$ & $\begin{array}{c}-0.2291 \\
(-0.57)\end{array}$ & $\begin{array}{c}0.4613 \\
(1.43)\end{array}$ & & $\begin{array}{l}4.5868 \\
(1.76)^{*}\end{array}$ & $\begin{array}{c}7.9190 \\
(3.13)^{* * *}\end{array}$ & $\begin{array}{l}2.6322 \\
(1.66)^{*}\end{array}$ & $\begin{array}{c}3.8500 \\
(2.71)^{* * *}\end{array}$ \\
\hline$(\Delta)$ PRICE & & $\begin{array}{c}-0.0135 \\
(-3.64)^{* * *}\end{array}$ & $\begin{array}{c}-0.0212 \\
(-5.52)^{* * *}\end{array}$ & $\begin{array}{c}-0.0097 \\
(-0.62)\end{array}$ & $\begin{array}{c}-0.0265 \\
(-2.24)^{* *}\end{array}$ & & $\begin{array}{c}-0.0416 \\
(-2.39)^{* *}\end{array}$ & $\begin{array}{c}-0.0427 \\
(-2.70)^{* * *}\end{array}$ & $\begin{array}{c}0.0740 \\
(0.74)\end{array}$ & $\begin{array}{c}-0.0414 \\
(-0.80)\end{array}$ \\
\hline$(\Delta)$ VOLUME & & $\begin{array}{c}-0.9946 \\
(-6.88)^{* * *}\end{array}$ & $\begin{array}{c}-0.8320 \\
(-6.68)^{* * *}\end{array}$ & $\begin{array}{c}-0.1577 \\
(-0.57)\end{array}$ & $\begin{array}{c}0.1154 \\
(0.51)\end{array}$ & & $\begin{array}{c}-1.9289 \\
(-4.05)^{* * *}\end{array}$ & $\begin{array}{c}-2.1631 \\
(-2.42)^{* *}\end{array}$ & $\begin{array}{l}1.7521 \\
(1.41)\end{array}$ & $\begin{array}{c}1.8847 \\
(2.21)^{* *}\end{array}$ \\
\hline DECIMAL & & $\begin{array}{c}1.5173 \\
(3.78)^{* * *}\end{array}$ & $\begin{array}{c}1.8292 \\
(4.69)^{* * *}\end{array}$ & $\begin{array}{c}-0.0285 \\
(-0.09)\end{array}$ & $\begin{array}{c}0.8343 \\
(3.12)^{* * *}\end{array}$ & & $\begin{array}{c}5.9819 \\
(3.84)^{* * *}\end{array}$ & $\begin{array}{c}10.6789 \\
(4.89)^{* * *}\end{array}$ & $\begin{array}{l}1.3011 \\
(1.14)\end{array}$ & $\begin{array}{c}3.4480 \\
(3.21)^{* * *}\end{array}$ \\
\hline BANKS & & $\begin{array}{c}-0.5169 \\
(-2.21)^{* *}\end{array}$ & $\begin{array}{c}0.0365 \\
(0.19)\end{array}$ & $\begin{array}{c}0.1922 \\
(0.91)\end{array}$ & $\begin{array}{c}0.7344 \\
(3.83)^{* * *}\end{array}$ & & $\begin{array}{l}-2.3320 \\
(-1.71)^{*}\end{array}$ & $\begin{array}{c}-0.6171 \\
(-0.54)\end{array}$ & $\begin{array}{c}-0.5874 \\
(-0.52)\end{array}$ & $\begin{array}{c}1.3603 \\
(1.59)\end{array}$ \\
\hline INSURERS & & $\begin{array}{l}-0.8700 \\
(-1.90)^{*}\end{array}$ & $\begin{array}{c}1.6553 \\
(2.98)^{* * *}\end{array}$ & $\begin{array}{c}-0.0054 \\
(-0.02)\end{array}$ & $\begin{array}{c}2.0238 \\
(4.99)^{* * *}\end{array}$ & & $\begin{array}{l}-5.1150 \\
(-2.28)^{* *}\end{array}$ & $\begin{array}{c}2.1360 \\
(1.30)\end{array}$ & $\begin{array}{c}-1.6980 \\
(-0.89)\end{array}$ & $\begin{array}{c}3.8652 \\
(3.24)^{* * *}\end{array}$ \\
\hline Constant & & $\begin{array}{c}7.2799 \\
(4.76)^{* * *}\end{array}$ & $\begin{array}{c}8.2854 \\
(6.37)^{* * *}\end{array}$ & $\begin{array}{c}0.8740 \\
(0.85)\end{array}$ & $\begin{array}{c}2.7581 \\
(2.86)^{* * *}\end{array}$ & & $\begin{array}{c}23.8169 \\
(3.21)^{* * *}\end{array}$ & $\begin{array}{c}25.9675 \\
(2.80)^{* * *}\end{array}$ & $\begin{array}{l}13.8492 \\
(2.50)^{* *}\end{array}$ & $\begin{array}{c}12.9904 \\
(2.95)^{* * *}\end{array}$ \\
\hline Number of observations & & 564 & 752 & 564 & 752 & & 564 & 752 & 564 & 752 \\
\hline $\begin{array}{l}\text { F-stat. all variables } \\
\quad[\text { Prob }>F]\end{array}$ & & $\begin{array}{c}5.49 \\
{[0.000]^{* * *}}\end{array}$ & $\begin{array}{c}6.80 \\
{[0.000]^{* * *}}\end{array}$ & $\begin{array}{c}1.54 \\
{[0.066]^{*}}\end{array}$ & $\begin{array}{c}3.16 \\
{[0.000]^{* * *}}\end{array}$ & & $\begin{array}{c}3.32 \\
{[0.000]^{* * *}}\end{array}$ & $\begin{array}{c}2.95 \\
{[0.000]^{* * *}}\end{array}$ & $\begin{array}{c}1.47 \\
{[0.086]^{*}}\end{array}$ & $\begin{array}{c}3.41 \\
{[0.000]^{* * *}}\end{array}$ \\
\hline $\begin{array}{l}\text { F-stat. governance \& risk management } \\
{[\text { Prob }>F]}\end{array}$ & & $\begin{array}{c}2.02 \\
{[0.074]^{*}}\end{array}$ & $\begin{array}{c}5.04 \\
{[0.000]^{* * *}}\end{array}$ & $\begin{array}{c}1.03 \\
{[0.400]}\end{array}$ & $\begin{array}{c}4.71 \\
{[0.000]^{* * *}}\end{array}$ & & $\begin{array}{c}0.43 \\
{[0.829]}\end{array}$ & $\begin{array}{c}4.88 \\
{[0.000]^{* * *}}\end{array}$ & $\begin{array}{c}1.18 \\
{[0.319]}\end{array}$ & $\begin{array}{c}3.67 \\
{[0.003]^{* * *}}\end{array}$ \\
\hline $\begin{array}{l}\text { F-stat. announcement characteristics } \\
{[\text { Prob }>F]}\end{array}$ & & $\begin{array}{c}2.38 \\
{[0.037]^{* *}}\end{array}$ & $\begin{array}{c}1.85 \\
{[0.101]}\end{array}$ & $\begin{array}{c}1.44 \\
{[0.210]}\end{array}$ & $\begin{array}{c}3.36 \\
{[0.005]^{* * *}}\end{array}$ & & $\begin{array}{c}3.16 \\
{[0.008]^{* * *}}\end{array}$ & $\begin{array}{c}2.88 \\
{[0.014]^{* *}}\end{array}$ & $\begin{array}{c}0.89 \\
{[0.488]}\end{array}$ & $\begin{array}{c}3.49 \\
{[0.004]^{* * *}}\end{array}$ \\
\hline$R^{2}$ & & 0.3423 & 0.3048 & 0.0415 & 0.1450 & & 0.1765 & 0.1590 & 0.0872 & 0.1141 \\
\hline$A I C$ & & $2,724.63$ & $3,645.45$ & $2,558.99$ & $3,404.97$ & & $4,516.69$ & $6,332.57$ & $4,049.67$ & $5,528.27$ \\
\hline$B I C$ & & $2,815.66$ & $3,742.52$ & $2,650.03$ & $3,502.05$ & & $4,607.73$ & $6,429.65$ & $4,140.71$ & $5,625.35$ \\
\hline
\end{tabular}


Panel B: Settlement announcements

\begin{tabular}{|c|c|c|c|c|c|c|c|c|c|c|}
\hline \multirow{3}{*}{ Variable } & \multirow[b]{3}{*}{$\begin{array}{l}\text { Exp. } \\
\text { Sign }\end{array}$} & \multicolumn{4}{|c|}{ Effective Spread } & \multirow[b]{3}{*}{$\begin{array}{l}\text { Exp. } \\
\text { Sign }\end{array}$} & \multicolumn{4}{|c|}{ Price Impact of Trade (30 min) } \\
\hline & & \multicolumn{2}{|c|}{ Level } & \multicolumn{2}{|c|}{ Change $(\Delta)$} & & \multicolumn{2}{|c|}{ Level } & \multicolumn{2}{|c|}{ Change $(\Delta)$} \\
\hline & & $\begin{array}{c}(1) \\
t=[-3,-1]\end{array}$ & $\begin{array}{c}(2) \\
t=[0,+3]\end{array}$ & $\begin{array}{c}(3) \\
t=[-3,-1]\end{array}$ & $\begin{array}{c}(4) \\
t=[0,+3]\end{array}$ & & $\begin{array}{c}(5) \\
t=[-3,-1]\end{array}$ & $\begin{array}{c}(6) \\
t=[0,+3]\end{array}$ & $\begin{array}{c}(7) \\
t=[-3,-1]\end{array}$ & $\begin{array}{c}(8) \\
t=[0,+3]\end{array}$ \\
\hline Governance and Risk Management: & & & & & & & & & & \\
\hline BOARD INDEPENDENCE & + & $\begin{array}{c}0.0013 \\
(0.15)\end{array}$ & $\begin{array}{c}0.0037 \\
(0.49)\end{array}$ & $\begin{array}{c}0.0039 \\
(0.55)\end{array}$ & $\begin{array}{c}0.0053 \\
(0.89)\end{array}$ & + & $\begin{array}{c}-0.0118 \\
(-0.58)\end{array}$ & $\begin{array}{l}-0.0326 \\
(-1.95)^{*}\end{array}$ & $\begin{array}{c}0.0119 \\
(0.48)\end{array}$ & $\begin{array}{c}0.0032 \\
(0.16)\end{array}$ \\
\hline INSIDER OWNERSHIP & + & $\begin{array}{c}0.0370 \\
(1.44)\end{array}$ & $\begin{array}{c}0.0567 \\
(2.32)^{* *}\end{array}$ & $\begin{array}{c}0.0224 \\
(1.28)\end{array}$ & $\begin{array}{c}0.0403 \\
(2.40)^{* *}\end{array}$ & + & $\begin{array}{l}0.1108 \\
(1.78)^{*}\end{array}$ & $\begin{array}{l}0.0876 \\
(1.71)^{*}\end{array}$ & $\begin{array}{c}0.0728 \\
(1.26)\end{array}$ & $\begin{array}{c}0.0755 \\
(1.50)\end{array}$ \\
\hline BLOCK OWNERSHIP & + & $\begin{array}{c}0.0056 \\
(0.51)\end{array}$ & $\begin{array}{c}0.0109 \\
(1.10)\end{array}$ & $\begin{array}{c}0.0168 \\
(2.22)^{* *}\end{array}$ & $\begin{array}{l}0.0136 \\
(1.92)^{*}\end{array}$ & + & $\begin{array}{c}0.0269 \\
(1.03)\end{array}$ & $\begin{array}{c}0.0175 \\
(1.03)\end{array}$ & $\begin{array}{c}0.0898 \\
(2.05)^{* *}\end{array}$ & $\begin{array}{c}0.0764 \\
(1.98)^{* *}\end{array}$ \\
\hline GINDEX & - & $\begin{array}{c}-0.0660 \\
(-1.56)\end{array}$ & $\begin{array}{c}-0.0364 \\
(-1.08)\end{array}$ & $\begin{array}{c}-0.0175 \\
(-0.49)\end{array}$ & $\begin{array}{c}0.0039 \\
(0.14)\end{array}$ & - & $\begin{array}{l}-0.1605 \\
(-1.66)^{*}\end{array}$ & $\begin{array}{c}-0.0029 \\
(-0.04)\end{array}$ & $\begin{array}{c}0.1569 \\
(1.18)\end{array}$ & $\begin{array}{c}0.3228 \\
(2.62)^{* * *}\end{array}$ \\
\hline RISK MANAGEMENT SCORE & + & $\begin{array}{c}-0.0988 \\
(-1.46)\end{array}$ & $\begin{array}{l}-0.0884 \\
(-1.80)^{*}\end{array}$ & $\begin{array}{c}-0.0241 \\
(-0.41)\end{array}$ & $\begin{array}{c}-0.0470 \\
(-1.13)\end{array}$ & + & $\begin{array}{c}-0.0581 \\
(-0.36)\end{array}$ & $\begin{array}{c}-0.2092 \\
(-2.26)^{* *}\end{array}$ & $\begin{array}{c}0.5169 \\
(2.52)^{* *}\end{array}$ & $\begin{array}{c}0.3043 \\
(1.97)^{* *}\end{array}$ \\
\hline Announcement Characteristics: & & & & & & & & & & \\
\hline INTERNAL FRAUD & + & $\begin{array}{c}0.3634 \\
(1.11)\end{array}$ & $\begin{array}{c}0.2718 \\
(0.93)\end{array}$ & $\begin{array}{c}0.4073 \\
(1.27)\end{array}$ & $\begin{array}{c}0.3402 \\
(1.29)\end{array}$ & + & $\begin{array}{c}0.9155 \\
(1.04)\end{array}$ & $\begin{array}{c}0.7402 \\
(1.45)\end{array}$ & $\begin{array}{c}-0.2811 \\
(-0.15)\end{array}$ & $\begin{array}{c}-0.8123 \\
(-0.48)\end{array}$ \\
\hline EXTERNAL FRAUD & - & $\begin{array}{c}-0.1800 \\
(-0.44)\end{array}$ & $\begin{array}{c}-0.3799 \\
(-1.38)\end{array}$ & $\begin{array}{c}0.2969 \\
(0.94)\end{array}$ & $\begin{array}{c}0.0020 \\
(0.01)\end{array}$ & - & $\begin{array}{l}-1.3798 \\
(-1.81)^{*}\end{array}$ & $\begin{array}{c}-0.5904 \\
(-1.25)\end{array}$ & $\begin{array}{l}1.2133 \\
(0.90)\end{array}$ & $\begin{array}{l}1.9464 \\
(1.72)^{*}\end{array}$ \\
\hline CLIENTS, PRODUCTS, \& BUS. PRACTICES & + & $\begin{array}{c}0.2821 \\
(1.09)\end{array}$ & $\begin{array}{c}0.2375 \\
(0.99)\end{array}$ & $\begin{array}{c}0.2749 \\
(1.22)\end{array}$ & $\begin{array}{c}0.2786 \\
(1.36)\end{array}$ & + & $\begin{array}{c}0.3434 \\
(0.57)\end{array}$ & $\begin{array}{l}0.6678 \\
(1.68)^{*}\end{array}$ & $\begin{array}{c}2.0959 \\
(1.46)\end{array}$ & $\begin{array}{c}3.1311 \\
(2.62)^{* * *}\end{array}$ \\
\hline DISCLOSED BY FIRM & + & $\begin{array}{c}0.2626 \\
(1.34)\end{array}$ & $\begin{array}{l}0.2726 \\
(1.74)^{*}\end{array}$ & $\begin{array}{l}0.2507 \\
(1.68)^{*}\end{array}$ & $\begin{array}{l}0.1980 \\
(1.65)^{*}\end{array}$ & + & $\begin{array}{c}0.5631 \\
(1.20)\end{array}$ & $\begin{array}{c}0.7685 \\
(2.33)^{* *}\end{array}$ & $\begin{array}{c}-1.1007 \\
(-1.54)\end{array}$ & $\begin{array}{c}-0.7576 \\
(-1.38)\end{array}$ \\
\hline LOSS ANNOUNCED & + & $\begin{array}{c}0.8007 \\
(2.95)^{* * *}\end{array}$ & $\begin{array}{c}0.9941 \\
(4.73)^{* * *}\end{array}$ & $\begin{array}{c}0.6335 \\
(1.55)\end{array}$ & $\begin{array}{c}0.9011 \\
(2.14)^{* *}\end{array}$ & + & $\begin{array}{c}1.9373 \\
(1.98)^{* *}\end{array}$ & $\begin{array}{c}2.1798 \\
(4.08)^{* * *}\end{array}$ & $\begin{array}{c}-0.8045 \\
(-0.74)\end{array}$ & $\begin{array}{c}-0.1702 \\
(-0.16)\end{array}$ \\
\hline Control Variables: & & & & & & & & & & \\
\hline NUMBER OF ANALYSTS & & $\begin{array}{c}0.1063 \\
(5.56)^{* * *}\end{array}$ & $\begin{array}{c}0.1074 \\
(6.51)^{* * *}\end{array}$ & $\begin{array}{c}-0.0042 \\
(-0.30)\end{array}$ & $\begin{array}{c}-0.0029 \\
(-0.24)\end{array}$ & & $\begin{array}{c}0.2254 \\
(4.47)^{* * *}\end{array}$ & $\begin{array}{c}0.1672 \\
(4.53)^{* * *}\end{array}$ & $\begin{array}{c}-0.0868 \\
(-1.21)\end{array}$ & $\begin{array}{c}-0.0909 \\
(-1.62)\end{array}$ \\
\hline FIRM SIZE & & $\begin{array}{c}0.4195 \\
(4.33)^{* * *}\end{array}$ & $\begin{array}{c}0.4783 \\
(5.94)^{* * *}\end{array}$ & $\begin{array}{c}0.0919 \\
(1.57)\end{array}$ & $\begin{array}{l}0.0917 \\
(1.80)^{*}\end{array}$ & & $\begin{array}{c}0.3067 \\
(1.10)\end{array}$ & $\begin{array}{c}0.6502 \\
(3.65)^{* * *}\end{array}$ & $\begin{array}{c}0.3806 \\
(1.07)\end{array}$ & $\begin{array}{c}0.6451 \\
(2.01)^{* *}\end{array}$ \\
\hline VOLATILITY & & $\begin{array}{c}-0.0223 \\
(-0.32)\end{array}$ & $\begin{array}{c}-0.0439 \\
(-0.75)\end{array}$ & $\begin{array}{c}-0.0445 \\
(-0.93)\end{array}$ & $\begin{array}{c}-0.0519 \\
(-1.30)\end{array}$ & & $\begin{array}{c}-0.4062 \\
(-2.35)^{* *}\end{array}$ & $\begin{array}{c}-0.1895 \\
(-1.38)\end{array}$ & $\begin{array}{c}-0.3196 \\
(-1.47)\end{array}$ & $\begin{array}{c}-0.1487 \\
(-0.81)\end{array}$ \\
\hline LEVERAGE & & $\begin{array}{c}0.4542 \\
(0.59)\end{array}$ & $\begin{array}{c}0.5498 \\
(0.96)\end{array}$ & $\begin{array}{c}-1.1371 \\
(-2.00)^{* *}\end{array}$ & $\begin{array}{l}-0.8260 \\
(-1.91)^{*}\end{array}$ & & $\begin{array}{c}1.5670 \\
(0.84)\end{array}$ & $\begin{array}{l}1.6275 \\
(1.51)\end{array}$ & $\begin{array}{c}-5.4502 \\
(-2.43)^{* *}\end{array}$ & $\begin{array}{c}-4.6825 \\
(-2.78)^{* * *}\end{array}$ \\
\hline BETA & & $\begin{array}{c}-0.2198 \\
(-0.78)\end{array}$ & $\begin{array}{c}0.0277 \\
(0.11)\end{array}$ & $\begin{array}{c}-0.0923 \\
(-0.45)\end{array}$ & $\begin{array}{c}0.2698 \\
(1.44)\end{array}$ & & $\begin{array}{c}1.7631 \\
(2.11)^{* *}\end{array}$ & $\begin{array}{l}1.2997 \\
(1.91)^{*}\end{array}$ & $\begin{array}{c}-0.1185 \\
(-0.12)\end{array}$ & $\begin{array}{c}0.2127 \\
(0.27)\end{array}$ \\
\hline$(\Delta)$ PRICE & & $\begin{array}{c}-0.0175 \\
(-4.45)^{* * *}\end{array}$ & $\begin{array}{c}-0.0198 \\
(-5.97)^{* * *}\end{array}$ & $\begin{array}{c}-0.0107 \\
(-1.34)\end{array}$ & $\begin{array}{l}-0.0108 \\
(-1.72)^{*}\end{array}$ & & $\begin{array}{l}-0.0237 \\
(-2.55)^{* *}\end{array}$ & $\begin{array}{c}-0.0336 \\
(-5.21)^{* * *}\end{array}$ & $\begin{array}{c}-0.0040 \\
(-0.09)\end{array}$ & $\begin{array}{c}-0.0529 \\
(-1.50)\end{array}$ \\
\hline$(\Delta)$ VOLUME & & $\begin{array}{c}-0.7165 \\
(-6.20)^{* * *}\end{array}$ & $\begin{array}{c}-0.8214 \\
(-9.52)^{* * *}\end{array}$ & $\begin{array}{c}0.2912 \\
(1.58)\end{array}$ & $\begin{array}{c}0.3716 \\
(3.44)^{* * *}\end{array}$ & & $\begin{array}{c}-0.7208 \\
(-3.19)^{* * *}\end{array}$ & $\begin{array}{c}-0.9068 \\
(-4.72)^{* * *}\end{array}$ & $\begin{array}{c}-0.2616 \\
(-0.25)\end{array}$ & $\begin{array}{c}0.7091 \\
(1.08)\end{array}$ \\
\hline DECIMAL & & $\begin{array}{c}1.6638 \\
(6.08)^{* * *}\end{array}$ & $\begin{array}{c}1.6915 \\
(7.23)^{* * *}\end{array}$ & $\begin{array}{c}-0.1091 \\
(-0.71)\end{array}$ & $\begin{array}{c}-0.0564 \\
(-0.41)\end{array}$ & & $\begin{array}{c}3.8586 \\
(6.51)^{* * *}\end{array}$ & $\begin{array}{c}3.6454 \\
(7.81)^{* * *}\end{array}$ & $\begin{array}{c}-2.9426 \\
(-2.95)^{* * *}\end{array}$ & $\begin{array}{c}-2.7555 \\
(-3.27)^{* * *}\end{array}$ \\
\hline BANKS & & $\begin{array}{c}-0.8064 \\
(-3.01)^{* * *}\end{array}$ & $\begin{array}{c}-0.5656 \\
(-2.54)^{* *}\end{array}$ & $\begin{array}{c}0.0790 \\
(0.38)\end{array}$ & $\begin{array}{c}0.1860 \\
(1.03)\end{array}$ & & $\begin{array}{c}-0.3703 \\
(-0.53)\end{array}$ & $\begin{array}{c}0.0039 \\
(0.01)\end{array}$ & $\begin{array}{c}2.0614 \\
(2.11)^{* *}\end{array}$ & $\begin{array}{c}1.9717 \\
(2.43)^{* *}\end{array}$ \\
\hline INSURERS & & $\begin{array}{c}-1.1227 \\
(-2.88)^{* * *}\end{array}$ & $\begin{array}{c}-0.7653 \\
(-2.80)^{* * *}\end{array}$ & $\begin{array}{c}-0.3643 \\
(-1.18)\end{array}$ & $\begin{array}{c}-0.1046 \\
(-0.53)\end{array}$ & & $\begin{array}{c}-0.5359 \\
(-0.50)\end{array}$ & $\begin{array}{c}0.2518 \\
(0.41)\end{array}$ & $\begin{array}{c}0.7057 \\
(0.71)\end{array}$ & $\begin{array}{c}1.4888 \\
(2.26)^{* *}\end{array}$ \\
\hline Constant & & $\begin{array}{c}4.2492 \\
(3.34)^{* * *}\end{array}$ & $\begin{array}{c}3.9648 \\
(3.64) * * *\end{array}$ & $\begin{array}{c}-1.7017 \\
(-1.99)^{* *}\end{array}$ & $\begin{array}{c}-2.9286 \\
(-3.67)^{* * *}\end{array}$ & & $\begin{array}{c}2.3731 \\
(0.78) \\
\end{array}$ & $\begin{array}{c}1.5794 \\
(0.66) \\
\end{array}$ & $\begin{array}{c}-3.1891 \\
(-0.68) \\
\end{array}$ & $\begin{array}{l}-10.1394 \\
(-2.47)^{* *}\end{array}$ \\
\hline Number of observations & & 864 & 1,150 & 864 & 1,150 & & 864 & 1,150 & 864 & 1,150 \\
\hline $\begin{array}{l}\text { F-stat. all variables } \\
{[\text { Prob }>F]}\end{array}$ & & $\begin{array}{c}7.00 \\
{[0.000]^{* * *}}\end{array}$ & $\begin{array}{c}10.36 \\
{[0.000]^{* * *}}\end{array}$ & $\begin{array}{c}1.41 \\
{[0.111]}\end{array}$ & $\begin{array}{c}2.30 \\
{[0.001]^{* * *}}\end{array}$ & & $\begin{array}{c}5.66 \\
{[0.000]^{* * *}}\end{array}$ & $\begin{array}{c}7.29 \\
{[0.000]^{* * *}}\end{array}$ & $\begin{array}{c}1.25 \\
{[0.203]}\end{array}$ & $\begin{array}{c}2.20 \\
{[0.002]^{* * *}}\end{array}$ \\
\hline $\begin{array}{l}\text { F-stat. governance \& risk management } \\
{[\text { Prob }>F]}\end{array}$ & & $\begin{array}{c}1.71 \\
{[0.129]}\end{array}$ & $\begin{array}{c}2.90 \\
{[0.013]^{* *}}\end{array}$ & $\begin{array}{c}1.95 \\
{[0.083]^{*}}\end{array}$ & $\begin{array}{c}2.99 \\
{[0.011]^{* *}}\end{array}$ & & $\begin{array}{c}2.74 \\
{[0.018]^{* *}}\end{array}$ & $\begin{array}{c}6.38 \\
{[0.000]^{* * *}}\end{array}$ & $\begin{array}{c}2.11 \\
{[0.062]^{*}}\end{array}$ & $\begin{array}{c}2.37 \\
{[0.038]^{* *}}\end{array}$ \\
\hline $\begin{array}{l}\text { F-stat. announcement characteristics } \\
{[\text { Prob }>F]}\end{array}$ & & $\begin{array}{c}2.98 \\
{[0.011]^{* *}}\end{array}$ & $\begin{array}{c}6.74 \\
{[0.000]^{* * *}}\end{array}$ & $\begin{array}{c}1.44 \\
{[0.206]}\end{array}$ & $\begin{array}{c}2.50 \\
{[0.029]^{* *}}\end{array}$ & & $\begin{array}{c}3.09 \\
{[0.009]^{* * *}}\end{array}$ & $\begin{array}{c}5.99 \\
{[0.000]^{* * *}}\end{array}$ & $\begin{array}{c}0.96 \\
{[0.440]}\end{array}$ & $\begin{array}{c}3.10 \\
{[0.009]^{* * *}}\end{array}$ \\
\hline$R^{2}$ & & 0.2489 & 0.3137 & 0.0323 & 0.0505 & & 0.1241 & 0.1723 & 0.0435 & 0.0640 \\
\hline$A I C$ & & $4,063.22$ & $5,315.28$ & $3,727.96$ & $4,832.68$ & & $5,667.84$ & $7,094.78$ & $6,450.64$ & $8,339.80$ \\
\hline$B I C$ & & $4,163.21$ & $5,421.28$ & $3,827.95$ & $4,938.68$ & & $5,767.84$ & $7,200.78$ & $6,550.63$ & $8,445.79$ \\
\hline
\end{tabular}


Figure 4: Risk Management in Firms with Operational Risk Announcements during 1995-2013

This figure illustrates the time series behavior of risk management traits of the firms in our sample.

Panel A: First announcements

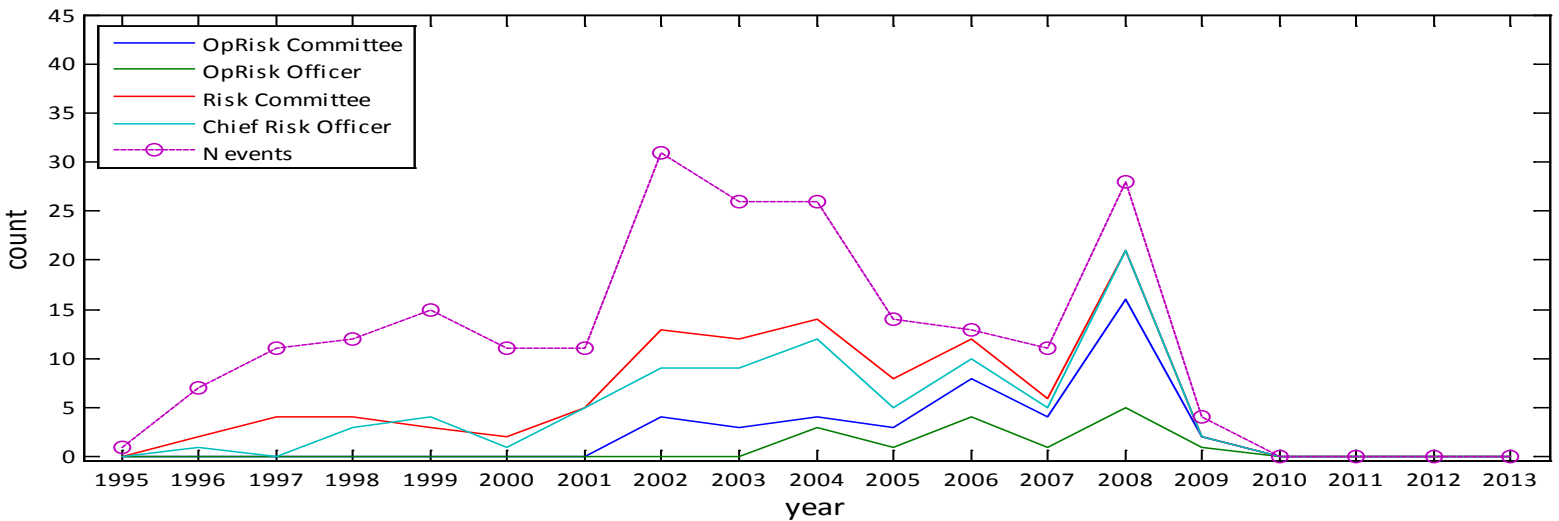

Panel B: Settlement announcements

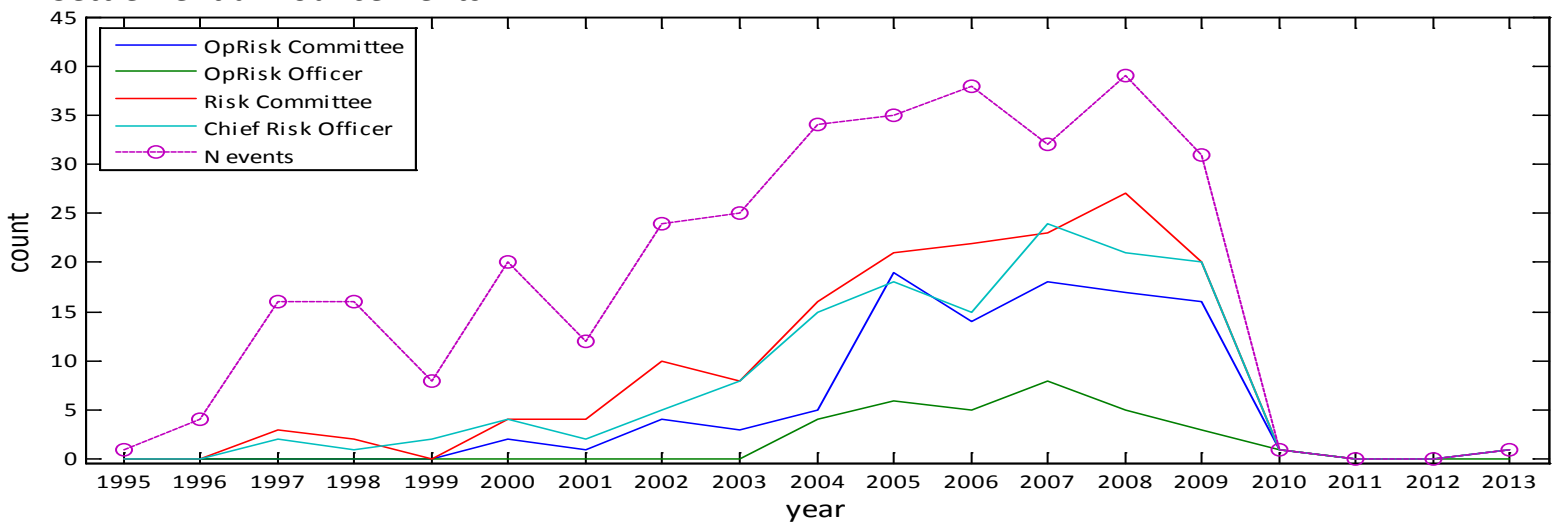

\section{Table 7: Descriptive Statistics of Risk Management Variables}

This table describes sample statistics of the risk management variables in our sample data, for events in firms with non-zero values of these variables.

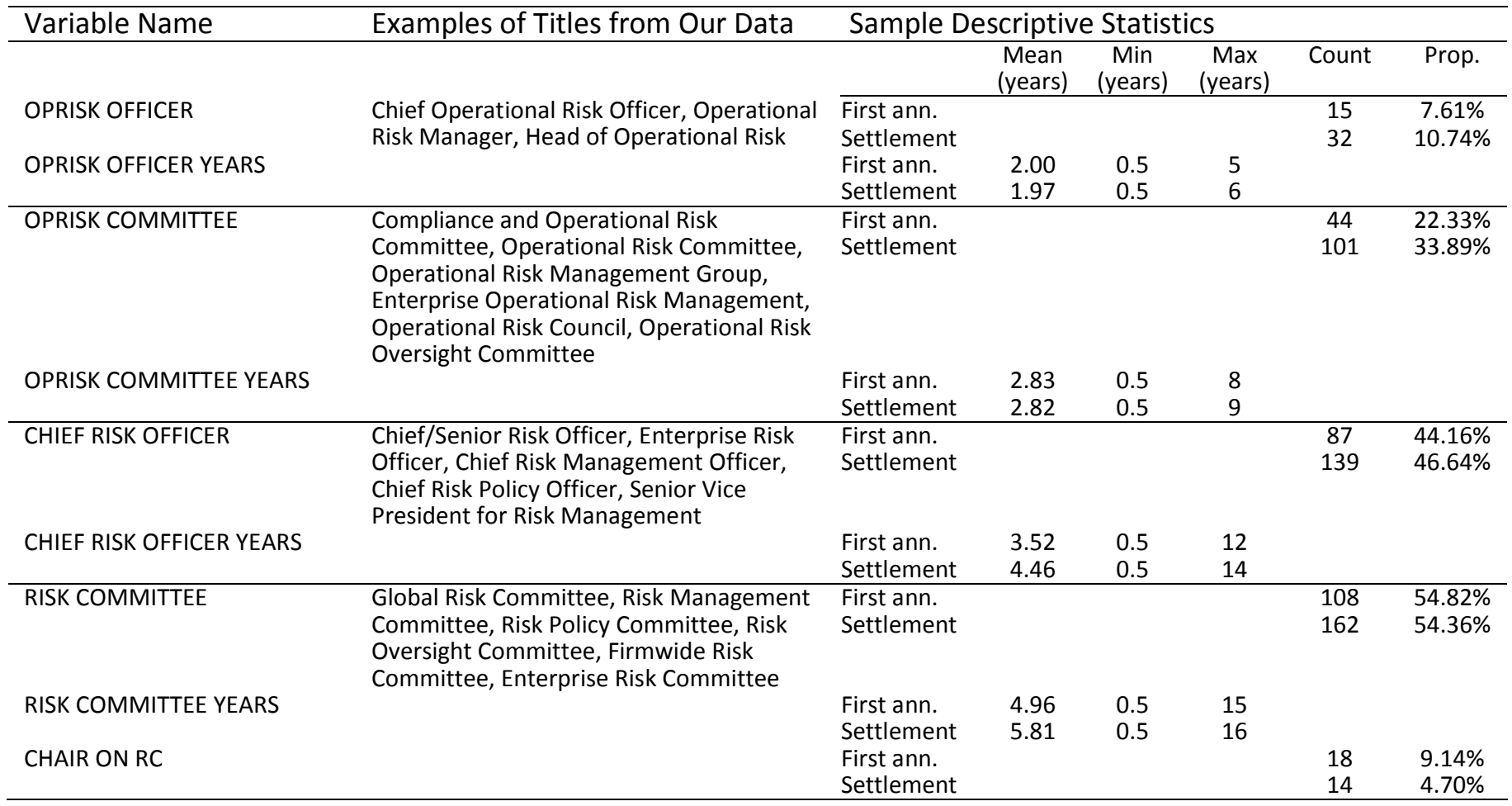


Table 8: Multivariate Results: Information Asymmetry and Risk Management

This table focuses on the impact of individual risk management variables on information asymmetry around operational risk announcements. The dependent variable is the change in price impact of trade from non-event period during the event window $t=[-3,+3]$. Models (1) and (5) in this table are Models (4) and (8) from Table 5, respectively. $t$-statistics based on heteroscedasticity-robust standard errors are reported in parentheses. Superscripts $* * *, * *$, and $*$ denote statistical significance at the $1 \%, 5 \%$, and $10 \%$ levels, respectively.

\begin{tabular}{|c|c|c|c|c|c|c|c|c|c|c|}
\hline \multirow{3}{*}{ Variable } & \multirow{3}{*}{$\begin{array}{l}\text { Exp. } \\
\text { Sign }\end{array}$} & \multicolumn{4}{|c|}{ First Announcements } & \multirow{3}{*}{$\begin{array}{l}\text { Exp. } \\
\text { Sign }\end{array}$} & \multicolumn{4}{|c|}{ Settlement Announcements } \\
\hline & & Change $(\Delta)$ & in Price $\mathrm{Im}$ & act of Trad & $\mathrm{e}(30 \mathrm{~min})$ & & Change $(\Delta)$ & in Price $I \mathrm{mr}$ & pact of Tra & de $(30 \mathrm{~min})$ \\
\hline & & (1) & (2) & (3) & $(4)$ & & $(5)$ & $(6)$ & (7) & $(8)$ \\
\hline Governance: & & & & & & & & & & \\
\hline BOARD INDEPENDENCE & - & $\begin{array}{c}-0.0294 \\
(-1.15)\end{array}$ & $\begin{array}{c}-0.0341 \\
(-1.28)\end{array}$ & $\begin{array}{l}-0.0216 \\
(-0.84)\end{array}$ & $\begin{array}{c}-0.0284 \\
(-1.03)\end{array}$ & + & $\begin{array}{c}0.0349 \\
(2.40)^{* *}\end{array}$ & $\begin{array}{l}0.0188 \\
(1.12)\end{array}$ & $\begin{array}{c}0.0130 \\
(0.84)\end{array}$ & $\begin{array}{l}0.0230 \\
(1.34)\end{array}$ \\
\hline INSIDER OWNERSHIP & - & $\begin{array}{l}-0.0661 \\
(-1.88)^{*}\end{array}$ & $\begin{array}{c}-0.0698 \\
(-1.99)^{* *}\end{array}$ & $\begin{array}{c}-0.0592 \\
(-1.60)\end{array}$ & $\begin{array}{c}-0.0540 \\
(-1.47)\end{array}$ & + & $\begin{array}{c}0.0995 \\
(2.77)^{* * *}\end{array}$ & $\begin{array}{c}0.0803 \\
(2.17)^{* *}\end{array}$ & $\begin{array}{c}0.0841 \\
(2.41)^{* *}\end{array}$ & $\begin{array}{c}0.0939 \\
(2.74)^{* * *}\end{array}$ \\
\hline BLOCK OWNERSHIP & - & $\begin{array}{l}-0.0363 \\
(-1.58)\end{array}$ & $\begin{array}{l}-0.0456 \\
(-1.94)^{*}\end{array}$ & $\begin{array}{l}-0.0265 \\
(-0.91)\end{array}$ & $\begin{array}{c}-0.0364 \\
(-1.19)\end{array}$ & + & $\begin{array}{c}0.0686 \\
(2.33)^{* *}\end{array}$ & $\begin{array}{c}0.0854 \\
(2.92)^{* * *}\end{array}$ & $\begin{array}{c}0.1044 \\
(3.53)^{* * *}\end{array}$ & $\begin{array}{c}0.1095 \\
(3.63)^{* * *}\end{array}$ \\
\hline GINDEX & + & $\begin{array}{c}-0.0792 \\
(-0.69)\end{array}$ & $\begin{array}{l}-0.1050 \\
(-0.96)\end{array}$ & $\begin{array}{l}-0.0595 \\
(-0.45)\end{array}$ & $\begin{array}{c}-0.0370 \\
(-0.28)\end{array}$ & - & $\begin{array}{l}0.1118 \\
(1.26)\end{array}$ & $\begin{array}{c}0.2002 \\
(2.38)^{* *}\end{array}$ & $\begin{array}{c}0.1360 \\
(1.43)\end{array}$ & $\begin{array}{c}0.1573 \\
(1.63)\end{array}$ \\
\hline Risk Management: & & & & & & & & & & \\
\hline RISK MANAGEMENT SCORE & - & $\begin{array}{l}0.3000 \\
(1.72)^{*}\end{array}$ & & & & + & $\begin{array}{l}0.2021 \\
(1.77)^{*}\end{array}$ & & & \\
\hline OPRISK OFFICER & - & & $\begin{array}{c}-1.5903 \\
(-0.80)\end{array}$ & & $\begin{array}{c}-1.5542 \\
(-0.80)\end{array}$ & + & & $\begin{array}{c}2.2611 \\
(1.98)^{* *}\end{array}$ & & $\begin{array}{c}2.5937 \\
(2.30)^{* *}\end{array}$ \\
\hline OPRISK OFFICER*OPRISK OFFICER YEARS & - & & $\begin{array}{l}0.3011 \\
(0.52)\end{array}$ & & $\begin{array}{l}0.1849 \\
(0.33)\end{array}$ & + & & $\begin{array}{l}0.4100 \\
(1.50)\end{array}$ & & $\begin{array}{l}0.1324 \\
(0.43)\end{array}$ \\
\hline ORISK COMMITTEE & - & & $\begin{array}{l}1.6595 \\
(1.65)^{*}\end{array}$ & & $\begin{array}{l}1.9155 \\
(1.67)^{*}\end{array}$ & + & & $\begin{array}{l}1.1215 \\
(1.52)\end{array}$ & & $\begin{array}{l}1.0367 \\
(1.00)\end{array}$ \\
\hline ORISK COMM*OPRISK COMM YEARS & - & & $\begin{array}{l}0.1190 \\
(0.53)\end{array}$ & & $\begin{array}{l}0.0717 \\
(0.30)\end{array}$ & + & & $\begin{array}{c}-0.3843 \\
(-3.03)^{* * *}\end{array}$ & & $\begin{array}{c}-0.3406 \\
(-2.48)^{* *}\end{array}$ \\
\hline CHIEF RISK OFFICER & - & & & $\begin{array}{c}-0.0599 \\
(-0.08)\end{array}$ & $\begin{array}{c}-0.2478 \\
(-0.35)\end{array}$ & + & & & $\begin{array}{c}1.7979 \\
(2.65)^{* * *}\end{array}$ & $\begin{array}{c}1.2748 \\
(2.14)^{* *}\end{array}$ \\
\hline CHIEF RISK OFFICIER*CRO YEARS & - & & & $\begin{array}{l}0.1179 \\
(1.16)\end{array}$ & $\begin{array}{l}0.0611 \\
(0.55)\end{array}$ & + & & & $\begin{array}{c}0.1867 \\
(2.31)^{* *}\end{array}$ & $\begin{array}{l}0.1671 \\
(1.76)^{*}\end{array}$ \\
\hline RISK COMMITTEE & - & & & $\begin{array}{c}-0.2943 \\
(-0.35)\end{array}$ & $\begin{array}{c}-0.5321 \\
(-0.55)\end{array}$ & + & & & $\begin{array}{c}-1.4893 \\
(-2.66)^{* * *}\end{array}$ & $\begin{array}{c}-2.1225 \\
(-2.59)^{* * *}\end{array}$ \\
\hline RISK COMMITTEE*RISK COMM YEARS & - & & & $\begin{array}{l}0.0712 \\
(0.78)\end{array}$ & $\begin{array}{l}0.0841 \\
(0.86)\end{array}$ & + & & & $\begin{array}{l}-0.1005 \\
(-1.93)^{*}\end{array}$ & $\begin{array}{c}-0.0651 \\
(-1.16)\end{array}$ \\
\hline RISK COMMITTEE*CHAIR ON RC & - & & & $\begin{array}{l}2.4836 \\
(1.93)^{*}\end{array}$ & $\begin{array}{c}2.8087 \\
(2.10)^{* *}\end{array}$ & + & & & $\begin{array}{l}1.6817 \\
(2.01)^{* *}\end{array}$ & $\begin{array}{c}1.7572 \\
(2.09)^{* *}\end{array}$ \\
\hline Announcement Characteristics: & & & & & & & & & & \\
\hline INTERNAL FRAUD & + & $\begin{array}{c}1.8281 \\
(2.57)^{* * *}\end{array}$ & $\begin{array}{c}1.7626 \\
(2.52)^{* *}\end{array}$ & $\begin{array}{c}1.6667 \\
(2.29)^{* *}\end{array}$ & $\begin{array}{c}1.5717 \\
(2.20)^{* *}\end{array}$ & + & $\begin{array}{c}-0.2614 \\
(-0.20)\end{array}$ & $\begin{array}{l}0.1181 \\
(0.09)\end{array}$ & $\begin{array}{l}-1.1645 \\
(-0.90)\end{array}$ & $\begin{array}{c}-0.4854 \\
(-0.35)\end{array}$ \\
\hline EXTERNAL FRAUD & + & $\begin{array}{c}-0.0502 \\
(-0.08)\end{array}$ & $\begin{array}{c}-0.2195 \\
(-0.33)\end{array}$ & $\begin{array}{l}-0.2938 \\
(-0.44)\end{array}$ & $\begin{array}{c}-0.6329 \\
(-0.90)\end{array}$ & - & $\begin{array}{c}2.1111 \\
(2.43)^{* *}\end{array}$ & $\begin{array}{c}2.3190 \\
(2.56)^{* *}\end{array}$ & $\begin{array}{l}0.9773 \\
(1.11)\end{array}$ & $\begin{array}{l}1.4399 \\
(1.57)\end{array}$ \\
\hline CLIENTS, PRODUCTS, \& BUS. PRACTICES & + & $\begin{array}{l}1.3605 \\
(1.82)^{*}\end{array}$ & $\begin{array}{l}1.1635 \\
(1.49)\end{array}$ & $\begin{array}{l}1.4294 \\
(1.93)^{*}\end{array}$ & $\begin{array}{l}1.2090 \\
(1.54)\end{array}$ & + & $\begin{array}{c}2.8729 \\
(3.32)^{* * *}\end{array}$ & $\begin{array}{c}3.2269 \\
(3.25)^{* * *}\end{array}$ & $\begin{array}{c}2.3383 \\
(2.47)^{* *}\end{array}$ & $\begin{array}{c}2.8890 \\
(2.80)^{* * *}\end{array}$ \\
\hline DISCLOSED BY FIRM & - & $\begin{array}{c}-0.4756 \\
(-1.03)\end{array}$ & $\begin{array}{c}-0.4513 \\
(-0.99)\end{array}$ & $\begin{array}{c}-0.7152 \\
(-1.49)\end{array}$ & $\begin{array}{l}-0.7350 \\
(-1.54)\end{array}$ & + & $\begin{array}{c}-0.6569 \\
(-1.62)\end{array}$ & $\begin{array}{c}-0.9283 \\
(-2.12)^{* *}\end{array}$ & $\begin{array}{c}-1.0348 \\
(-2.32)^{* *}\end{array}$ & $\begin{array}{c}-1.0725 \\
(-2.40)^{* *}\end{array}$ \\
\hline LOSS ANNOUNCED & - & $\begin{array}{c}1.2339 \\
(2.06)^{* *}\end{array}$ & $\begin{array}{c}1.2283 \\
(1.98)^{* *}\end{array}$ & $\begin{array}{l}1.0983 \\
(1.73)^{*}\end{array}$ & $\begin{array}{l}1.0494 \\
(1.61)\end{array}$ & + & $\begin{array}{r}-0.4417 \\
(-0.56)\end{array}$ & $\begin{array}{l}-0.0455 \\
(-0.06)\end{array}$ & $\begin{array}{r}-0.6534 \\
(-0.82)\end{array}$ & $\begin{array}{c}-0.4559 \\
(-0.54)\end{array}$ \\
\hline Control Variables & & Yes & Yes & Yes & Yes & & Yes & Yes & Yes & Yes \\
\hline Number of observations & & 1,316 & 1,316 & 1,316 & 1,316 & & 2,014 & 2,014 & 2,014 & 2,014 \\
\hline F-stat. all variables & & 3.34 & 3.03 & 3.18 & 2.93 & & 2.70 & 3.20 & 2.95 & 3.20 \\
\hline$[$ Prob $>F]$ & & {$[0.000]^{* * *}$} & {$[0.000]^{* * *}$} & {$[0.000]^{* * *}$} & {$[0.000]^{* * *}$} & & {$[0.000]^{* * *}$} & {$[0.000]^{* * *}$} & {$[0.000]^{* *}$} & {$[0.000]^{* * *}$} \\
\hline F-stat. risk management & & & 1.16 & 1.58 & 1.46 & & & 5.40 & 4.48 & 3.66 \\
\hline$[$ Prob $>F]$ & & & [0.325] & [0.163] & {$[0.158]$} & & {$[0.000]^{* * *}$} & {$[0.000]^{* * *}$} & {$[0.001]^{* * *}$} & {$[0.000]^{* * *}$} \\
\hline$R^{2}$ & & 0.0821 & 0.0830 & 0.0860 & 0.0889 & & 0.0780 & 0.0548 & 0.0623 & 0.0678 \\
\hline$A I C$ & & $9,573.49$ & $9,578.19$ & $9,575.90$ & $9,579.77$ & & $14,707.46$ & $14,763.69$ & $17,749.46$ & $14,745.73$ \\
\hline$B I C$ & & $9,682.32$ & $9,702.56$ & $9,705.46$ & $9,730.06$ & & $14,825.23$ & $14,898.28$ & $14,889.66$ & $14,908.36$ \\
\hline
\end{tabular}




\section{Table 9: Robustness Checks for Determinants of Information Asymmetry}

This table presents the results of robustness checks. The dependent variable is the change in price impact of trade from nonevent period during $t=[-3,+3]$. Model 0 in Panel A is Model (4) for first announcements and in Panel B is Model (8) for the settlement announcements from Table 5, respectively. In RC1 the dependent variable is the average change in effective spread per transaction during the event period, and the data is in cross-section form. In RC2 we exclude the post-credit crisis period. Additionally, we run separate models for fraud (RC3), Clients, Products, and Business Practices events (RC4), and all other events (RC5). In RC6 we include year fixed effects. In RC7 we eliminate events disclosed during scheduled earnings announcements or restatement announcements. In RC8, we redefine our risk management score as an additive index obtained by the sum of six risk management variables: OPRISK OFFICER, OPRISK COMMITTEE, CHAIR ON OPRISK COMMITTEE, CHIEF RISK OFFICER, RISK COMMITTEE, and CHAIR ON RISK COMMITTEE. $t$-statistics based on heteroscedasticity-robust standard errors are reported in parentheses. Superscripts $* * *, * *$, and $*$ denote statistical significance at the $1 \%, 5 \%$, and $10 \%$ levels, respectively.

Panel A: Change in price impact of trade around first announcements

\begin{tabular}{|c|c|c|c|c|c|c|c|c|c|c|}
\hline Variable & $\begin{array}{l}\text { Exp. } \\
\text { Sign }\end{array}$ & $\begin{array}{c}\text { Model } 0 \\
\text { Table 5: } \\
\text { Model (4) }\end{array}$ & $\begin{array}{c}\text { RC1 } \\
\text { Cross- } \\
\text { Section } \\
\end{array}$ & $\begin{array}{l}\text { RC2 } \\
\text { Pre- } \\
\text { Crisis } \\
\end{array}$ & $\begin{array}{l}\text { RC3 } \\
\text { Events: } \\
\text { Fraud }\end{array}$ & $\begin{array}{c}\text { RC4 } \\
\text { Events: } \\
\text { CPBP }\end{array}$ & $\begin{array}{c}\text { RC5 } \\
\text { Events: } \\
\text { Other } \\
\end{array}$ & $\begin{array}{c}\text { RC6 } \\
\text { Incl. Year } \\
\text { Fixed Eff. }\end{array}$ & $\begin{array}{c}\text { RC7 } \\
\text { Excl. Earn. } \\
\text { Ann. }\end{array}$ & $\begin{array}{c}\text { RC8 } \\
\text { RM } \\
\text { Score }\end{array}$ \\
\hline \multirow{2}{*}{$\begin{array}{l}\text { Governance \& Risk Mangmt: } \\
\text { BOARD INDEPENDENCE }\end{array}$} & & & & & & & & & & \\
\hline & - & $\begin{array}{c}-0.0294 \\
(-1.15)\end{array}$ & $\begin{array}{c}-0.0279 \\
(-0.68)\end{array}$ & $\begin{array}{c}-0.0299 \\
(-1.13)\end{array}$ & $\begin{array}{c}-0.0157 \\
(-0.71)\end{array}$ & $\begin{array}{c}-0.0161 \\
(-0.36)\end{array}$ & $\begin{array}{c}0.0307 \\
(0.22)\end{array}$ & $\begin{array}{c}-0.0167 \\
(-0.61)\end{array}$ & $\begin{array}{c}-0.0208 \\
(-0.75)\end{array}$ & $\begin{array}{c}-0.0319 \\
(-1.25)\end{array}$ \\
\hline INSIDER OWNERSHIP & - & $\begin{array}{l}-0.0661 \\
(-1.88)^{*}\end{array}$ & $\begin{array}{c}-0.0579 \\
(-1.03)\end{array}$ & $\begin{array}{l}-0.0648 \\
(-1.83)^{*}\end{array}$ & $\begin{array}{c}-0.1264 \\
(-1.16)\end{array}$ & $\begin{array}{c}-0.0387 \\
(-0.81)\end{array}$ & $\begin{array}{c}0.1892 \\
(0.76)\end{array}$ & $\begin{array}{l}-0.0770 \\
(-2.10)^{* *}\end{array}$ & $\begin{array}{l}-0.0652 \\
(-1.81)^{*}\end{array}$ & $\begin{array}{l}-0.0690 \\
(-1.90)^{*}\end{array}$ \\
\hline BLOCK OWNERSHIP & - & $\begin{array}{c}-0.0363 \\
(-1.58)\end{array}$ & $\begin{array}{c}-0.0359 \\
(-1.07)\end{array}$ & $\begin{array}{c}-0.0341 \\
(-1.49)\end{array}$ & $\begin{array}{c}0.0066 \\
(0.31)\end{array}$ & $\begin{array}{c}-0.0834 \\
(-1.99)^{* *}\end{array}$ & $\begin{array}{c}-0.0210 \\
(-0.13)\end{array}$ & $\begin{array}{c}-0.0284 \\
(-1.25)\end{array}$ & $\begin{array}{l}-0.0405 \\
(-1.67)^{*}\end{array}$ & $\begin{array}{c}-0.0349 \\
(-1.52)\end{array}$ \\
\hline GINDEX & + & $\begin{array}{l}-0.0792 \\
(-0.69)\end{array}$ & $\begin{array}{l}-0.0693 \\
(-0.37)\end{array}$ & $\begin{array}{l}-0.0795 \\
(-0.66)\end{array}$ & $\begin{array}{c}-0.1353 \\
(-0.91)\end{array}$ & $\begin{array}{l}-0.1503 \\
(-0.85)\end{array}$ & $\begin{array}{c}0.1788 \\
(1.09)\end{array}$ & $\begin{array}{l}0.0142 \\
(0.10)\end{array}$ & $\begin{array}{l}-0.0299 \\
(-0.25)\end{array}$ & $\begin{array}{l}-0.0838 \\
(-0.73)\end{array}$ \\
\hline RISK MANAGEMENT SCORE & - & $\begin{array}{l}0.3000 \\
(1.72)^{*}\end{array}$ & $\begin{array}{l}0.2979 \\
(0.91)\end{array}$ & $\begin{array}{l}0.3131 \\
(1.60)\end{array}$ & $\begin{array}{c}0.0420 \\
(0.29)\end{array}$ & $\begin{array}{c}0.5945 \\
(2.50)^{* *}\end{array}$ & $\begin{array}{l}-0.3394 \\
(-0.57)\end{array}$ & $\begin{array}{c}0.5498 \\
(2.55)^{* *}\end{array}$ & $\begin{array}{l}0.4215 \\
(2.16)^{* *}\end{array}$ & $\begin{array}{l}0.5116 \\
(1.61)\end{array}$ \\
\hline \multicolumn{11}{|l|}{ Announcement Characteristics: } \\
\hline INTERNAL FRAUD & + & $\begin{array}{c}1.8281 \\
(2.57)^{* * *}\end{array}$ & $\begin{array}{l}1.8641 \\
(1.59)\end{array}$ & $\begin{array}{c}1.8876 \\
(2.60)^{* * *}\end{array}$ & & & & $\begin{array}{c}2.0833 \\
(2.74)^{* * *}\end{array}$ & $\begin{array}{l}1.9186 \\
(2.28)^{* *}\end{array}$ & $\begin{array}{l}1.7969 \\
(2.52)^{* *}\end{array}$ \\
\hline EXTERNAL FRAUD & + & $\begin{array}{c}-0.0502 \\
(-0.08)\end{array}$ & $\begin{array}{c}-0.0243 \\
(-0.02)\end{array}$ & $\begin{array}{c}-0.1889 \\
(-0.28)\end{array}$ & & & & $\begin{array}{c}0.3290 \\
(0.58)\end{array}$ & $\begin{array}{c}-1.2408 \\
(-1.39)\end{array}$ & $\begin{array}{c}-0.0290 \\
(-0.04)\end{array}$ \\
\hline CLIENTS, PROD., \& BUS. PRAC. & + & $\begin{array}{l}1.3605 \\
(1.82)^{*}\end{array}$ & $\begin{array}{l}1.4094 \\
(1.12)\end{array}$ & $\begin{array}{l}1.3334 \\
(1.69)^{*}\end{array}$ & & & & $\begin{array}{l}1.5488 \\
(1.95)^{*}\end{array}$ & $\begin{array}{l}0.8933 \\
(1.08)\end{array}$ & $\begin{array}{l}1.3865 \\
(1.87)^{*}\end{array}$ \\
\hline DISCLOSED BY FIRM & - & $\begin{array}{l}-0.4756 \\
(-1.03)\end{array}$ & $\begin{array}{l}-0.5370 \\
(-0.68)\end{array}$ & $\begin{array}{l}-0.5479 \\
(-1.09)\end{array}$ & $\begin{array}{l}-0.8856 \\
(-2.13)^{* *}\end{array}$ & $\begin{array}{c}-0.4281 \\
(-0.58)\end{array}$ & $\begin{array}{c}1.9499 \\
(0.85)\end{array}$ & $\begin{array}{c}-0.4277 \\
(-0.88)\end{array}$ & $\begin{array}{l}0.1599 \\
(0.32)\end{array}$ & $\begin{array}{l}-0.6100 \\
(-1.25)\end{array}$ \\
\hline LOSS ANNOUNCED & - & $\begin{array}{c}1.2339 \\
(2.06)^{* *}\end{array}$ & $\begin{array}{l}1.2502 \\
(1.15)\end{array}$ & $\begin{array}{c}1.3345 \\
(2.15)^{* *}\end{array}$ & $\begin{array}{l}1.2647 \\
(1.69)^{*}\end{array}$ & $\begin{array}{c}2.0435 \\
(2.43)^{* *}\end{array}$ & $\begin{array}{l}1.2058 \\
(1.11)\end{array}$ & $\begin{array}{l}0.6956 \\
(1.10)\end{array}$ & $\begin{array}{c}1.4739 \\
(2.31)^{* *}\end{array}$ & $\begin{array}{c}1.2193 \\
(2.01)^{* *}\end{array}$ \\
\hline \multicolumn{11}{|l|}{ Control Variables: } \\
\hline NUMBER OF ANALYSTS & & & $\begin{array}{c}0.1364 \\
(1.02)\end{array}$ & $\begin{array}{l}0.1308 \\
(1.87)^{*}\end{array}$ & $\begin{array}{c}-0.0740 \\
(-1.35)\end{array}$ & $\begin{array}{c}0.2772 \\
(2.71)^{* * *}\end{array}$ & $\begin{array}{c}-0.0977 \\
(-0.31)\end{array}$ & $\begin{array}{c}0.0967 \\
(1.31)\end{array}$ & $\begin{array}{c}0.1826 \\
(2.38)^{* *}\end{array}$ & $\begin{array}{l}0.1233 \\
(1.82)^{*}\end{array}$ \\
\hline FIRM SIZE & & $\begin{array}{c}-1.5782 \\
(-4.32)^{* * *}\end{array}$ & $\begin{array}{c}-1.5623 \\
(-2.10)^{* *}\end{array}$ & $\begin{array}{c}-1.5613 \\
(-4.39)^{* * *}\end{array}$ & $\begin{array}{l}-0.18 \\
(-0.6\end{array}$ & $\begin{array}{c}-2.4363 \\
(-4.74)^{* * *}\end{array}$ & $\begin{array}{c}0.3794 \\
(0.35)\end{array}$ & $\begin{array}{c}-1.3672 \\
(-4.64)^{* * *}\end{array}$ & $\begin{array}{c}-1.8424 \\
(-4.38)^{* * *}\end{array}$ & $\begin{array}{c}-1.5343 \\
*(-4.28)^{* * *}\end{array}$ \\
\hline VOLATILITY & & $\begin{array}{c}-0.3659 \\
(-1.37)\end{array}$ & $\begin{array}{c}-0.3892 \\
(-0.90)\end{array}$ & $\begin{array}{c}-0.3462 \\
(-0.84)\end{array}$ & $\begin{array}{c}0.0538 \\
(0.17)\end{array}$ & $\begin{array}{r}0.443 \\
(0.75\end{array}$ & $\begin{array}{c}-1.0798 \\
(-0.75)\end{array}$ & $\begin{array}{c}1.5563 \\
(1.61)\end{array}$ & $\begin{array}{c}-0.1873 \\
(-0.72)\end{array}$ & $\begin{array}{c}-0.3276 \\
(-1.19)\end{array}$ \\
\hline LEVERAGE & & $\begin{array}{c}-0.7955 \\
(-0.40)\end{array}$ & $\begin{array}{c}-0.6017 \\
(-0.26)\end{array}$ & $\begin{array}{c}-0.9776 \\
(-0.48)\end{array}$ & $\begin{array}{l}2.92 \\
(1.4\end{array}$ & $\begin{array}{l}0.55 \\
(0.1\end{array}$ & $\begin{array}{c}-6.1424 \\
(-1.41)\end{array}$ & $\begin{array}{l}-0.9416 \\
(-0.46)\end{array}$ & $\begin{array}{c}-0.1200 \\
(-0.07)\end{array}$ & $\begin{array}{c}-1.0719 \\
(-0.54)\end{array}$ \\
\hline BETA & & $\begin{array}{c}3.3125 \\
(3.14)^{* * *}\end{array}$ & $\begin{array}{c}3.1489 \\
(1.55)\end{array}$ & $\begin{array}{c}3.4281 \\
(3.02)^{* * *}\end{array}$ & $\begin{array}{c}-1.6574 \\
(-1.64)\end{array}$ & $\begin{array}{c}2.0706 \\
(1.50)\end{array}$ & & $\begin{array}{l}1.3647 \\
(1.11)\end{array}$ & $\begin{array}{c}3.5712 \\
(3.32)^{* * *}\end{array}$ & $\begin{array}{c}3.3367 \\
(3.21)^{* * *}\end{array}$ \\
\hline$(\Delta)$ PRICE & & $\begin{array}{c}-0.0078 \\
(-0.16)\end{array}$ & $\begin{array}{l}0.0101 \\
(0.26)\end{array}$ & $\begin{array}{c}-0.0094 \\
(-0.16)\end{array}$ & $\begin{array}{c}-0.0276 \\
(-1.43)\end{array}$ & $\begin{array}{l}0.0019 \\
(0.02)\end{array}$ & $\begin{array}{c}-0.0911 \\
(-0.65)\end{array}$ & $\begin{array}{c}-0.0213 \\
(-0.43)\end{array}$ & $\begin{array}{c}-0.0050 \\
(-0.1)\end{array}$ & $\begin{array}{c}-0.0076 \\
(-0.16)\end{array}$ \\
\hline$(\Delta)$ VOLUME & & $\begin{array}{c}1.8413 \\
(2.59)^{* * *}\end{array}$ & $\begin{array}{c}2.4429 \\
(2.55)^{* *}\end{array}$ & $\begin{array}{c}1.9667 \\
(2.60)^{* * *}\end{array}$ & $\begin{array}{c}1.8397 \\
(4.18)^{* * *}\end{array}$ & $\begin{array}{c}2.8188 \\
(2.52)^{* *}\end{array}$ & $\begin{array}{c}-1.9428 \\
(-1.42)\end{array}$ & $\begin{array}{r}1.6 \\
(2.3\end{array}$ & $\begin{array}{c}1.8735 \\
(2.43)^{* *}\end{array}$ & $\begin{array}{c}1.8303 \\
(2.57)^{* * *}\end{array}$ \\
\hline DECIMAL & & $\begin{array}{c}2.5379 \\
(3.23)^{* * *}\end{array}$ & $\begin{array}{c}2.4654 \\
(1.65)\end{array}$ & $\begin{array}{c}2.5494 \\
(3.17)^{* * *}\end{array}$ & $\begin{array}{c}-0.2760 \\
(-0.46)\end{array}$ & $\begin{array}{c}5.5665 \\
(3.84)^{* * *}\end{array}$ & $\begin{array}{c}-2.0096 \\
(-0.39)\end{array}$ & $\begin{array}{c}30.4391 \\
(22.12)^{* * *}\end{array}$ & $\begin{array}{c}2.6060 \\
* \quad(3.2)^{* * *}\end{array}$ & $\begin{array}{c}2.4589 \\
(3.05)^{* * *}\end{array}$ \\
\hline BANKS & & $\begin{array}{c}0.5328 \\
(0.76)\end{array}$ & $\begin{array}{c}0.5373 \\
(0.47)\end{array}$ & $\begin{array}{c}0.7189 \\
(0.89)\end{array}$ & $\begin{array}{c}0.6342 \\
(1.23)\end{array}$ & $\begin{array}{c}1.2694 \\
(1.15)\end{array}$ & $\begin{array}{c}2.2277 \\
(2.52)^{* *}\end{array}$ & $\begin{array}{c}0.6667 \\
(0.74)\end{array}$ & $\begin{array}{l}1.0953 \\
(1.53)\end{array}$ & $\begin{array}{c}0.4277 \\
(0.62)\end{array}$ \\
\hline INSURERS & & $\begin{array}{c}1.5359 \\
(1.38)\end{array}$ & $\begin{array}{c}1.4025 \\
(1.03)\end{array}$ & $\begin{array}{c}1.5849 \\
(1.37)\end{array}$ & $\begin{array}{c}5.0655 \\
(3.62)^{* * *}\end{array}$ & $\begin{array}{c}1.1109 \\
(0.59)\end{array}$ & $\begin{array}{c}2.9351 \\
(0.43)\end{array}$ & $\begin{array}{c}0.5194 \\
(0.44)\end{array}$ & $\begin{array}{c}2.0571 \\
(1.98)^{* *}\end{array}$ & $\begin{array}{c}1.5462 \\
(1.39)\end{array}$ \\
\hline Constant & & $\begin{array}{c}13.7076 \\
(3.83)^{* * *}\end{array}$ & $\begin{array}{l}13.5552 \\
(2.31)^{* *}\end{array}$ & $\begin{array}{c}13.4720 \\
(3.70)^{* * *}\end{array}$ & $\begin{array}{l}6.8448 \\
(1.75)^{*}\end{array}$ & $\begin{array}{c}19.4936 \\
(4.03)^{* * *}\end{array}$ & $\begin{array}{c}-14.6852 \\
(-1.10)\end{array}$ & $\begin{array}{l}-28.2306 \\
(-4.15)^{* * *}\end{array}$ & $\begin{array}{r}14.0954 \\
(3.72)^{* * *} \\
\end{array}$ & $\begin{array}{c}13.1202 \\
(3.82)^{* * *} \\
\end{array}$ \\
\hline Num & & & 188 & 1,260 & 364 & 777 & & 1,316 & 1,190 & 1,316 \\
\hline & & & & 3.28 & 3.70 & 3.39 & & 82.04 & & \\
\hline & & {$[0.000]^{* * *}$} & {$[0.092]^{*}$} & {$[0.000]^{* * *}$} & {$[0.000]^{* *}$} & ${ }^{*}[0.000]^{* * *}$ & {$[0.000]^{* *}$} & $*[0.000]^{* *}$ & ${ }^{*}[0.000]^{* *}$ & {$[0.000]^{* * *}$} \\
\hline $\begin{array}{l}\text { F-stat. govern. \& risk mangmt } \\
{[\text { Prob }>F]}\end{array}$ & & $\begin{array}{c}3.65 \\
{[0.003]^{* * *}}\end{array}$ & $\begin{array}{c}1.22 \\
{[0.300]}\end{array}$ & $\begin{array}{c}3.52 \\
{[0.004]^{* * *}}\end{array}$ & $\begin{array}{c}1.05 \\
{[0.391]}\end{array}$ & $\begin{array}{c}3.91 \\
{[0.002]^{* * *}}\end{array}$ & $\begin{array}{c}2.04 \\
{[0.076]^{* *}}\end{array}$ & $\begin{array}{c}4.93 \\
{[0.000]^{* * *}}\end{array}$ & $\begin{array}{c}3.83 \\
* 0.002]^{* * *}\end{array}$ & $\begin{array}{c}3.66 \\
* 0.003]^{* * *}\end{array}$ \\
\hline $\begin{array}{l}\text { F-stat. announcement charact. } \\
{[\text { Prob }>F]}\end{array}$ & & $\begin{array}{c}3.13 \\
{[0.008]^{* * *}}\end{array}$ & $\begin{array}{c}1.38 \\
{[0.236]}\end{array}$ & $\begin{array}{c}3.28 \\
{[0.006]^{* * *}}\end{array}$ & $\begin{array}{c}2.73 \\
{[0.067]^{*}}\end{array}$ & $\begin{array}{c}3.05 \\
{[0.048]^{* *}}\end{array}$ & $\begin{array}{c}0.69 \\
{[0.501]}\end{array}$ & $\begin{array}{c}2.35 \\
{[0.039]^{* *}}\end{array}$ & $\begin{array}{c}4.02 \\
{[0.001]^{* * *}}\end{array}$ & $\begin{array}{c}3.11 \\
* 0.009]^{* * *}\end{array}$ \\
\hline$R^{2}$ & & 0.0821 & 0.1931 & 0.0828 & 0.2531 & & 0.2150 & 0.1417 & 0.0925 & 0.0827 \\
\hline$A I C$ & & & & & & & $1,134.48$ & & $8,688.68$ & $9,572.62$ \\
\hline$B I C$ & & $9,682.32$ & $1,279.17$ & $9,328.48$ & $2,131.87$ & $6,026.01$ & $1,191.45$ & $9,687.45$ & $8,795.40$ & $9,681.45$ \\
\hline
\end{tabular}


Panel B: Change in price impact of trade around settlement announcements

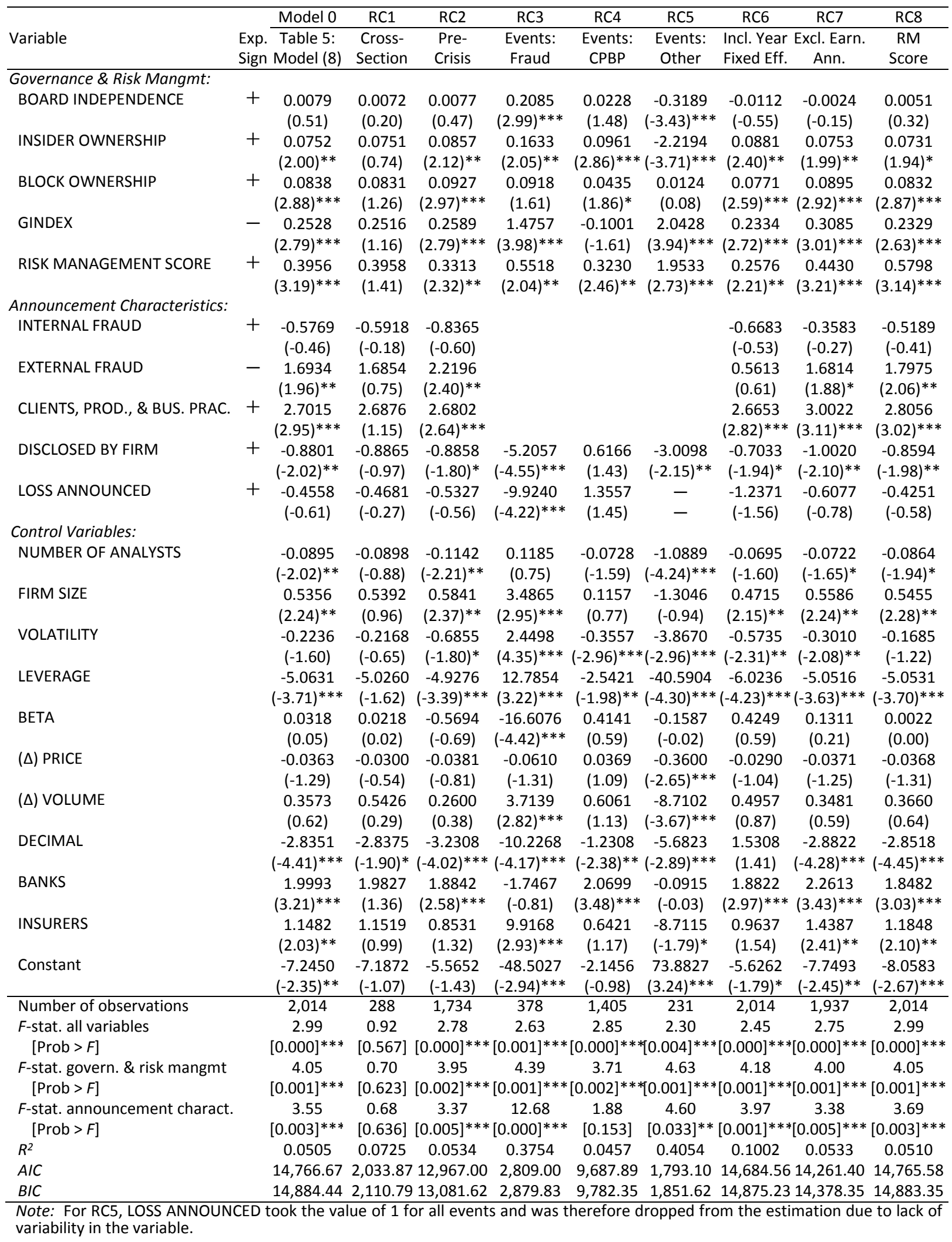




\section{Table 10: Simultaneous Determination of Liquidity and Information Asymmetry}

This table presents the results of the simultaneous equations model for the determinants of liquidity and information asymmetry around first announcements and settlement announcements of operational risk events. For each of the four specifications, the dependent variable is the change in daily quoted depth in the first equation, and change in a daily measure of information asymmetry from the non-event period during the event window $t=[-3,+3]$. The two measures of information asymmetry are effective spread $(\Delta \mathrm{ES})$ and price impact of trade $(30 \mathrm{~min})(\Delta \mathrm{PIT})$. $t$-statistics based on heteroscedasticity-robust standard errors are reported in parentheses. Superscripts $* * *, * *$, and * denote statistical significance at the $1 \%, 5 \%$, and $10 \%$ levels, respectively.

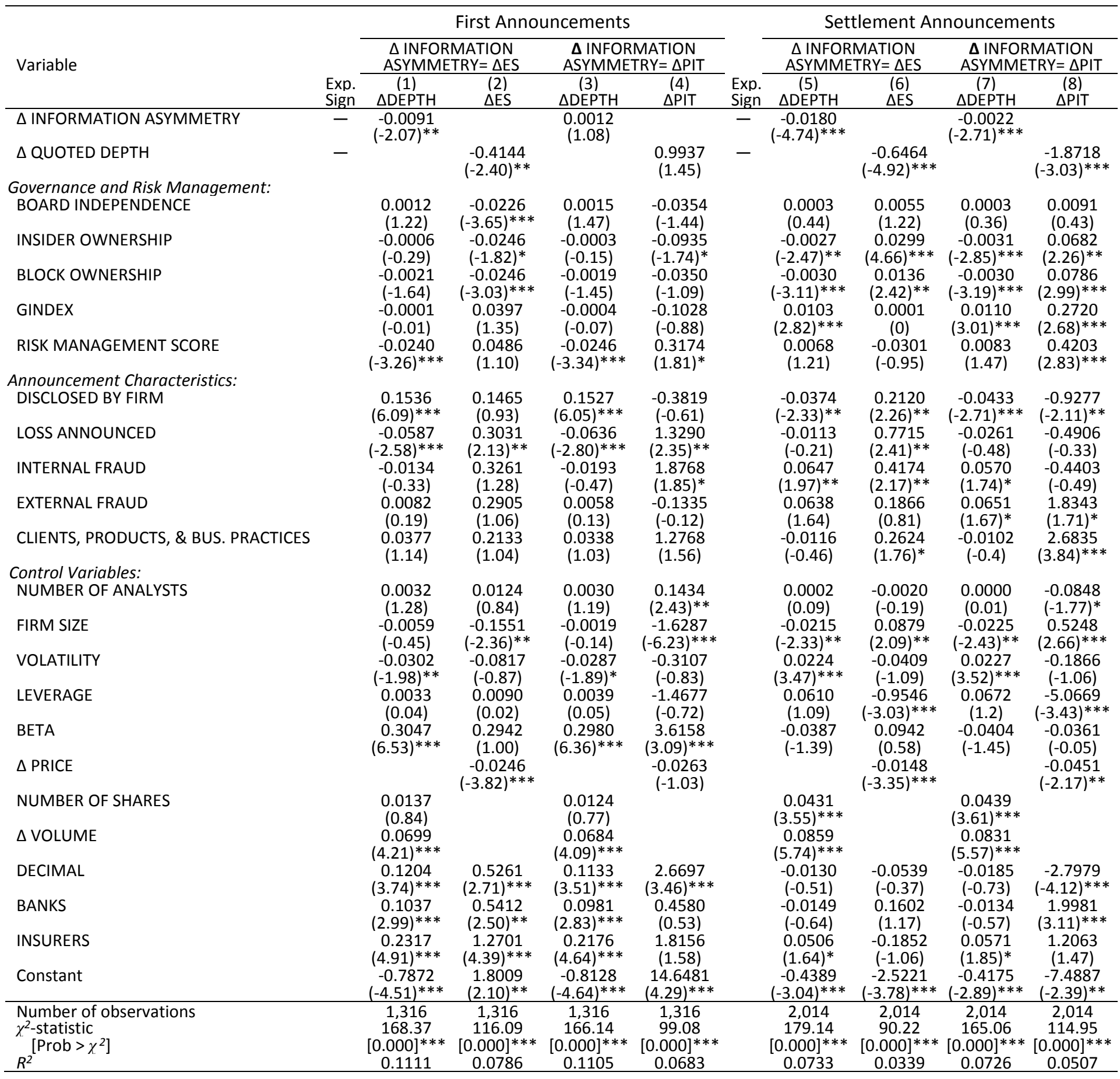

